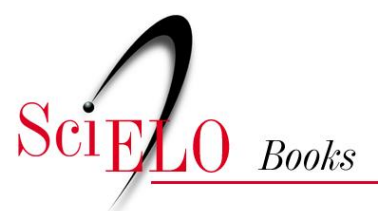

\title{
O judiciário em debate
}

\author{
Maria Tereza Sadek (org.)
}

SADEK, MT., org. O judiciário em debate [online]. Rio de Janeiro: Centro Edelstein de Pesquisas Sociais, 2010. 119 p. ISBN: 978-85-7982-034-2. Available from SciELO Books <http://books.scielo.org>.

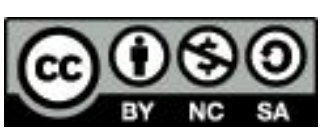

All the contents of this chapter, except where otherwise noted, is licensed under a Creative Commons Attribution-Non Commercial-ShareAlike 3.0 Unported.

Todo o conteúdo deste capítulo, exceto quando houver ressalva, é publicado sob a licença Creative Commons Atribuição Uso Não Comercial - Partilha nos Mesmos Termos 3.0 Não adaptada.

Todo el contenido de este capítulo, excepto donde se indique lo contrario, está bajo licencia de la licencia Creative Commons Reconocimento-NoComercial-CompartirIgual 3.0 Unported. 


\section{BIBLIOTECA VIRTUAL DE CIÊNCIAS HUMANAS}

\section{O JUDICIÁRIO EM DEBATE}

\section{Maria Tereza Sadek}

Organizadora

centro edelstein de pesquisas sociais
www.centroedelstein.org.br 


\title{
O judiciário em debate
}

\author{
Centro Edelstein de Pesquisas Sociais \\ www.centroedelstein.org.br \\ Rua Visconde de Pirajá, 330/1205 \\ Ipanema - Rio de Janeiro - RJ \\ CEP: 22410-000. Brasil \\ Contato: bvce@centroedelstein.org.br
} 位ação para uso comercial sem a permissão escrita dos proprietarios dos direitos autorais. A publicação ou partes dela podem ser reproduzidas para propósito não comercial na medida em que a origem da publicação, assim como seus autores, seja reconhecida.

ISBN 978-85-7982-034-2 


\section{SUMÁRIO}

\section{Apresentação}

Primeira sessão

O Judiciário e o acesso à Justiça

Segunda Sessão.

Organização e funcionamento do Poder Judiciário

Terceira Sessão.

O Judiciário na atual estrutura constitucional

Anexo: A pesquisa.

O que é o IDESP.

Nota sobre os expositores 119

\section{APRESENTAÇÃO}

Quem são e o que pensam os magistrados? Como encaram as inevitáveis implicações sociais e políticas de sua missão básica - a aplicação do Direito? Como reagem às críticas que vêm sendo feitas à sua atuação? É adequada a presente organização judiciária do país, ou existe necessidade de mudanças? Que pensam sobre estas questões os demais integrantes do sistema de justiça promotores, advogados, delegados - e as organizações da sociedade civil?

O Judiciário praticamente não tem sido estudado pelos cientistas sociais brasileiros. Não há uma tradição de pesquisa, nem uma literatura que possa servir de base a cursos universitários, nem uma massa crítica de especialistas aptos a intervir no debate público. O que há, realmente, é uma enorme lacuna. Foi com o objetivo de preenchê-la que o IDESP - Instituto de Estudos Econômicos, Sociais e Políticos de São Paulo - deu início a um amplo programa de trabalho sobre o Judiciário. A presente publicação e a pesquisa em que se baseia são os primeiros resultados desse esforço.

A pesquisa foi realizada no segundo semestre de 1993 por uma equipe coordenada por Maria Tereza Sadek e integrada por Rogério Bastos Arantes, Maria da Glória Bonelli, Gessé Marques Jr. e Fábio José Kerche Nunes. Foram entrevistados cerca de $20 \%$ dos juízes em cinco estados - São Paulo, Rio Grande do Sul, Paraná, Goiás e Pernambuco - e mais 41 da Justiça Federal, totalizando 570 entrevistas, observando-se rigorosa proporcionalidade em relação à distribuição dos mesmos entre as instâncias e entrâncias existentes em cada estado. A escolha daqueles cinco estados teve como objetivo representar a diversidade regional do país e eventuais singularidades na composição ou na atuação da magistratura.

O questionário utilizado na pesquisa, com 25 perguntas, focaliza a chamada "crise do judiciário" sob três ângulos principais: o institucional, o estrutural e o relativo aos procedimentos. $\mathrm{O}$ ângulo institucional refere-se à posição do Judiciário na organização tripartite dos poderes, com os dilemas daí decorrentes; o estrutural diz respeito a sua organização e hierarquia interna; o processual indica os efeitos e dificuldades que podem decorrer das próprias etapas e garantias especificadas em lei. A pesquisa procurou também captar a inclinação doutrinária (ou ideológica) dos entrevistados frente à tensão sempre presente entre o Direito positivo e o sentimento pessoal de justiça. 
Distribuição dos juízes da Justiça Comum e dos entrevistados entre os 5 estados (números absolutos)

\begin{tabular}{lcc}
\hline Estados & Juízes (*) & Entrevistados \\
Goiás & 170 & 36 \\
Pernambuco & 308 & 75 \\
Paraná & 318 & 48 \\
Rio Grande do Sul & 387 & 73 \\
São Paulo & 1520 & 297 \\
\hline (*) Banco Nacional de Dados do Poder Judiciário, agosto de 1992
\end{tabular}

Os resultados da pesquisa foram submetidos a amplo debate em abril de 1994, do qual participaram estudiosos, representantes da sociedade civil e integrantes do próprio sistema de justiça. Este volume reproduz integralmente as exposições e as intervenções do plenário.

Mais que em outras áreas da ciência social, um programa de estudos como este depende da colaboração da magistratura, dos profissionais a ela ligados e de pesquisadores acadêmicos. Não existe no Brasil, como dissemos, uma tradição de pesquisa a respeito do Judiciário. Muitos magistrados têm dúvidas sobre a conveniência de se exporem ao debate público, mesmo sob a forma impessoal de quadros estatísticos. Neste sentido, cumpre-nos consignar aqui o nosso agradecimento a todos os entrevistados, aos participantes do seminário e à Fundação Ford, e nosso desejo de que esta publicação contribua de alguma forma para o aperfeiçoamento da Justiça em nosso país.

Maria Tereza Sadek

\section{PRIMEIRA SESSÃO}

\section{O Judiciário e o acesso à Justiça}

\section{Moderadora: Floriza Verucci \\ Expositores: Sérgio Adorno}

Sueli Carneiro

Celso Campilongo

Joaquim Falcão

\section{Floriza Verucci}

Esta primeira mesa versará sobre o Judiciário e o Acesso à Justiça, contando com a participação de Sérgio Adorno, Sueli Carneiro, Celso Campilongo e Joaquim Falcão.

A questão que vai ser discutida diz respeito ao exercício da cidadania, pois refere-se ao acesso à justiça e, ao mesmo tempo, à garantia da cidadania pelo judiciário. A dificuldade do acesso indica um distanciamento talvez muito grande do Judiciário em relação à sociedade brasileira hoje, e o IDESP, ao promover este debate, está contribuindo de uma maneira excepcional para a superação desse estado de coisas. O Brasil está hoje colocando absolutamente tudo em questão: já questionamos o Executivo, com o impeachment, estamos questionando o Legislativo e talvez seja o momento de começarmos a questionar também o Judiciário, com o objetivo último de recuperar a plena legitimidade dos poderes da República.

Antes de iniciarmos as exposições, passo a palavra ao professor Bolívar Lamounier.

\section{Bolívar Lamounier}

Permitam-me uma intervenção de dois minutos para fazer um simples registro. O IDESP - Instituto de Estudos Econômicos, Sociais e Políticos de São Paulo, é uma instituição autônoma, privada, de caráter acadêmico, apartidária, sem fins lucrativos. Nós nos dedicamos à pesquisa e à promoção do debate público, isto é, à publicação de pesquisas e à organização de seminários para promover a discussão de questões relevantes para a sociedade brasileira. 
Naturalmente, não poderíamos empreender um trabalho dessa natureza que esperamos prosseguir por um bom período -, sobre as instituições ligadas à justiça, sem a colaboração de várias outras instituições, algumas das quais aqui representadas. Também não poderíamos empreender esse esforço sem o apoio material de fundações e entidades de financiamento à pesquisa. Neste sentido, quero registrar a presença aqui no auditório da $\mathrm{Dr}^{\mathrm{a}}$ Sonia Alvarez, representante da Fundação Ford, que nos apoiou na realização deste trabalho, e registrar também, com enorme satisfação, que se encontram aqui pessoas que vieram dos estados mais distantes, para participar desta discussão e para nos ajudar neste trabalho. Muito obrigado a todos.

\section{Floriza Verucci}

Dou inicialmente a palavra ao sociólogo Sérgio Adorno.

\section{Sérgio Adorno}

Vou fazer um relato de uma pesquisa que se acha em curso no Núcleo de Estudos da Violência e que está sendo realizada em convênio com o Geledés Instituto da Mulher Negra. O objetivo principal da pesquisa é identificar, caracterizar e explicar as razões do acesso diferencial de brancos e negros à justiça criminal. Para atingir esse objetivo, estamos analisando a distribuição de sentenças judiciárias para crimes de idêntica natureza cometidos por brancos e negros. Partimos da hipótese de que a justiça criminal é mais severa com criminosos negros do que com criminosos brancos. Há uma longa tradição de pesquisas desse tipo nos EUA, na Inglaterra e na França. Não sei se estudos dessa natureza já terão sido feitos no Brasil.

O universo empírico da pesquisa foi constituído pelos processos penais instaurados no município de São Paulo para apurar a responsabilidade por crimes violentos, julgados no ano de 1990. Tomei como base uma amostra estratificada representativa. Os dados foram levantados nas varas centrais do fórum da comarca da capital e eu me restringi à chamada criminalidade violenta: roubos, crimes de estupro e tráfico de drogas. Deixei para uma segunda fase os crimes dolosos contra a vida, que são objeto do tribunal do júri.

$\mathrm{O}$ que a pesquisa enfoca são dilemas e desafios que se colocam à justiça criminal numa ordem democrática. Um desses dilemas diz respeito ao papel do aparelho judiciário como mediador de conflitos sociais. Em uma ordem democrática, espera-se que o aparelho judiciário atue menos como instrumento de conformidade social e mais como instrumento de administração de conflitos sociais e de conflitos intersubjetivos, e que seja, portanto, um instrumento para a consecução de direitos consagrados no pacto constitucional.

A ordem democrática tem como pressuposto a progressiva remoção dos obstáculos econômicos, sociais e culturais que se manifestam sob a forma de acesso diferencial à justiça. No caso da justiça criminal, a discriminação materializa-se, sobretudo na distribuição desigual de sanções punitivas. Réus procedentes de estratos sociais distintos não recebem o mesmo tratamento legal ao cometerem idêntico delito. Aqueles que dispõem de recursos ou fortuna pessoal são menos vulneráveis à punição. Ao que tudo indica, a condição de pobreza constitui requisito para a condenação e cumprimento de pena. Entre os réus pobres, suspeita-se que haja também outros critérios sutis, porém poderosos, de discriminação. Os negros parecem ainda mais vulneráveis que os brancos à sanção punitiva. A cor revela-se grande obstáculo ao acesso à justiça criminal.

Foi pensando nesse problema que o projeto de pesquisa se propôs a investigar o acesso diferencial de brancos e negros à justiça criminal. $\mathrm{O}$ objetivo geral é conhecer os processos sociais que promovem a exclusão de direitos, as modalidades de ação judicial que fazem com que seja maior a probabilidade de um cidadão negro acusado de prática delinquencial, réu em processo penal, ser punido, comparativamente a um cidadão branco em situação idêntica. Quais as causas e consequências do tratamento diferencial? Como poderemos superar essas limitações de uma justiça restritiva e, nesse sentido, não democrática?

É uma pesquisa complexa, do ponto de vista metodológico. São necessárias precauções, para que os critérios de cientificidade da pesquisa possam ser resguardados. Primeiro, só podemos comparar crimes de idêntica natureza, visto que mesmo pequenas diferenças podem implicar penas diferentes. Assim, é necessário distinguir o que se deve a privilégios e o que se deve à natureza do crime. Crimes diferentes podem ensejar penas maiores ou menores; assim, é necessário todo um trabalho prévio, que a comparação seja feita entre crimes rigorosamente iguais, com penas previstas rigorosamente iguais. Outro cuidado metodológico importante é verificar se os direitos estão sendo assegurados igualmente para brancos e negros. Em tese, a variação da pena pode decorrer de desigualdades no acesso à justiça e aos serviços judiciais. Nesse sentido, a pesquisa precisa verificar se, de fato, se trata de um problema racial ou um problema ligado ao acesso à justiça. 
Outro problema complicado e que nós, sociólogos, gostamos de trabalhar com números, com frequências, com regularidades, e muitas vezes tomamos como unidade de observação o processo penal. O processo penal é um documento complexo, cuja análise requer certo treinamento, mas às vezes um mesmo processo envolve diversos infratores, diversas vítimas e um número também variável de testemunhas. A análise fica complicada porque não podemos excluir infratores, não dispomos de nenhum critério prévio para definir qual é mais e qual é menos importante. Tampouco podemos selecionar subjetivamente os crimes; ou seja, precisamos montar toda uma estratégia técnico-metodológica para incluir na análise todos os infratores e todas as vítimas.

Os resultados que vou relatar são ainda preliminares. Ainda não completamos o processamento dos dados. Foram analisados 475 processos. A amostra estatística estava estimada para mais ou menos 513 processos, mas alguns não foram localizados, e outros estavam em andamento e não podiam ser consultados.

Uma das suposições da pesquisa, como disse, é que a contribuição de réus brancos e negros para a fenomenologia da criminalidade urbana violenta é idêntica. Ou seja, partimos do pressuposto, que é também o pressuposto das pesquisas norte-americanas, de que brancos e negros cometem crimes na mesma proporção; de que não há uma inclinação preferencial dos negros ou dos brancos a cometerem crimes. Esse é um pressuposto, não uma hipótese que possamos comprovar diretamente, porque nãoforam feitas pesquisas no Brasil sobre este ponto. É um pressuposto baseado na revisão da literatura estrangeira, que sempre parte desse princípio, algumas delas com demonstrações convincentes de que a etnia não indica nenhuma preferência pela opção criminal. Nada sugere que um desses grupos esteja mais inclinado à prática dos crimes considerados violentos.

Uma questão importante, para a qual não disponho ainda de uma resposta satisfatória, é quem são as vítimas preferenciais dos réus brancos, comparativamente às vítimas preferenciais dos réus negros. Essa pergunta foi feita porque a literatura estrangeira mostra que a justiça é mais severa com os negros quando os negros vitimizam cidadãos brancos. Quando eles vitimizam cidadãos negros ou quando os brancos vitimizam negros ou os brancos vitimizam brancos, a literatura mostra que a pena não é tão severa. Ela é mais severa quando a vítima é branca e o agressor é negro.

Os resultados que vou relatar têm como referência o roubo qualificado. O roubo qualificado corresponde a quase $50 \%$ de todos os casos analisados. A maior parte dos crimes concentra-se nessa categoria. No que concerne a esse tipo criminal, os réus brancos tendem a agredir cidadãos do sexo masculino, na faixa etária de 10 a 19 anos, naturais da região Sudeste do país, em particular procedentes do Estado de São Paulo, e ocupados em atividades típicas dos estratos médios. No caso das ocorrências criminais praticadas por réus negros, o perfil das vítimas é o mesmo, com pequenas variações.

Quanto ao perfil do infrator, verificou-se que os réus brancos autores de roubo compreendem pessoas do sexo masculino, na faixa etária de 19 a 29 anos, naturais também da região Sudeste, também com maior peso para aqueles procedentes do Estado de São Paulo, na maior parte desempregados ou desocupados, com primeiro grau incompleto, com antecedentes criminais, porém na maioria juridicamente primários. Observe-se que esse perfil não difere substancialmente da composição demográfica e social da população urbana, a maior parte da qual é constituída por trabalhadores pobres, de baixa escolaridade, situados à margem do mercado formal de trabalho. Também não difere substancialmente do perfil das vítimas, embora essas pareçam situadas um pouco acima na escala da estratificação social. Tudo leva a crer, portanto, que as vítimas e agressores brancos sejam recrutados nos mesmos grupos sociais. Em outras palavras, pobres agredindo e vitimizando pobres.

Os réus negros apresentam um perfil ligeiramente diferenciado, o que pode eventualmente influenciar os resultados da ação penal. A principal diferença é que, embora a concentração na faixa etária seja a mesma, há uma concentração levemente maior dos negros nas faixas iniciais, isto é, entre 19 e 24 anos. Sem pretender oferecer aqui uma explicação definitiva, sugiro duas hipóteses: ou os negros estão ingressando mais cedo na delinquência, ou, o que me parece mais provável, eles são mais vulneráveis à sanção punitiva e são mais visados pela vigilância policial.

Por fim, permitam-me relatar alguns dados relativos ao desfecho processual. Um aspecto interessante diz respeito à confissão. Tanto réus negros quanto réus brancos tendem, na sua grande maioria, a confirmar os crimes que lhes são imputados num inquérito policial. Na fase policial, tanto brancos quanto negros, tendem a confirmar os crimes. $\mathrm{Na}$ fase judicial, a maior parte dos réus nega a confissão anterior, mas a negativa é menos frequente entre os réus negros que entre os réus brancos. Essa observação pode estar relacionada com a natureza da defesa: advogado dativo ou advogado constituído. É também possível que réus negros tenham menos credibilidade frente às autoridades: não só frente à autoridade judiciária, mas também às autoridades policiais. 
É perceptível a maior concentração de infratores, tanto brancos quanto negros, presos em flagrante delito. No entanto, é significativo observar a maior concentração de réus negros submetidos à prisão provisória do que réus brancos. Trata-se de um resultado muito importante, pois significa que os infratores negros constituem alvo preferencial da ação policial, possivelmente uma ação arbitrária.

Outro aspecto importante diz respeito às garantias processuais. Nesse caso, os negros também parecem desfavorecidos. Em média arrolam menos testemunhas do que os réus brancos. Isso possivelmente tem a ver com as estratégias da defensoria. Vale notar um outro aspecto: majoritariamente, réus brancos tendem a ter advogados constituídos, enquanto réus negros têm advogados dativos nomeados pelo Estado. Essa situação, ao que parece desfavorável para os infratores negros, pode ser resultado da situação de pobreza destes.

Sabemos que, entre os pobres, os negros são mais pobres, o que os priva do acesso a defensorias tecnicamente mais consistentes e disponíveis para a causa a ser defendida.

No cômputo geral, infratores negros são quantitativamente menos punidos do que cidadãos brancos, mas a punição de um réu negro é qualitativamente superior à de um réu branco. Provavelmente, os negros são mais perseguidos pela atividade policial do que os brancos. Sabemos, pelas nossas tradições penais, o peso de um inquérito policial na definição dos desdobramentos do processo penal.

Como essa perseguição é hipoteticamente mais rigorosa e arbitrária sobre os cidadãos negros, as ações penais convergem para um desfecho absolutório por falta de provas materiais ou devido a ausência de requisitos necessários a precisa imputação de responsabilidade penal.

Quero concluir dizendo que, até este momento, cheguei a três resultados parciais. Primeiro, réus negros tendem a ser alvo privilegiado da ação policial arbitrária. Segundo, réus negros tendem a ter maiores dificuldades de acesso à justiça penal, por isso entendendo-se maiores dificuldades de se valerem dos benefícios legais que podem, por assim dizer, suavizar a aplicação penal. Terceiro, quando punidos, os réus negros acabam sendo alvo de penas mais severas.

\section{Floriza Verucci}

Obrigada ao professor Sérgio Adorno por sua exposição, que começa a evidenciar as carências e os absurdos da aplicação da justiça. Passo agora a palavra a Sueli Carneiro.

\section{Sueli Carneiro}

Quero começar esta discussão do acesso à justiça tomando como referência uma frase do sociólogo Paulo Sérgio Pinheiro, que me parece paradigmática do que ocorre na sociedade brasileira em relação às possibilidades de acesso à justiça dos segmentos discriminados socialmente. "Na sociedade brasileira pode-se afirmar sem nenhum exagero que a maioria da população, aquela que compõe os $70 \%$ de pobres, indigentes e miseráveis, não tem os direitos individuais assegurados. Todos os direitos que lhes estão reconhecidos pela Constituição não têm uma tradução concreta no seu cotidiano".

As palavras de Paulo Sérgio Pinheiro são exemplares no que diz respeito ao sentimento dos segmentos socialmente marginalizados diante da questão do acesso à justiça. Contudo e paradoxalmente, esses mesmos setores socialmente marginalizados lutam e organizam-se no sentido de conquistar ou assegurar seus direitos de cidadania

E encontram no Estado e suas instituições os principais entraves para a realização de suas conquistas legais. A trajetória política do movimento de mulheres e do movimento negro do Brasil são ilustrativas dessas contradições.

Um pouco de História: 1988 foi um ano de particular importância para as mulheres brasileiras, quando vimos contempladas na nova Constituição bandeiras de lutas históricas do movimento de mulheres. O conjunto de direitos conquistados pelas mulheres na nova Constituição foi resultado de um amplo processo de mobilização e organização política ao longo dos últimos 20 anos. Uma das mais importantes conquistas desse processo está no Artigo 226 do texto constitucional, que diz em um de seus incisos: "O Estado assegurará a assistência à família na pessoa de cada um dos que a integram, criando mecanismos para coibir a violência no âmbito de suas relações". Esse dispositivo coroa a luta dos movimentos de mulheres contra a violência sofrida pelas mulheres, que era até então considerada uma questão de foro íntimo e que as mulheres organizadas transformaram em questão política, social e cultural.

Porém, enquanto a sociedade cada vez mais incorpora a violência contra a mulher como uma prática social que deve ser extirpada, persiste, conforme relata a Angélica Maria de Almeida, o fato de que, mesmo recorrendo à autoridade policial, muitas vezes a mulher é ridicularizada, quando não apontada como conivente ou provocadora da atitude agressiva, ensejando por esse motivo que a agressão sexual não seja objeto nem mesmo de registro policial, e, portanto não 
chegue à justiça. Assim sendo, o próprio titular do direito introjeta a banalização da violência e, ao tomar alguma iniciativa, não encontra ressonância por parte da autoridade encarregada de apurar os fatos.

Numa e outra situação, a minimização da conduta discriminatória faz com que não haja registro da mesma e como consequência a justiça não toma conhecimento da violação do direito e da conduta discriminatória.

O Inciso 20 do Artigo 7 dos Direitos Sociais prevê proteção do mercado de trabalho da mulher, mediante incentivos específicos nos termos da lei. Através desse dispositivo, o movimento de mulheres buscou garantir a redução gradual das desigualdades historicamente acumuladas pelas mulheres em função da discriminação sexual, abrindo brechas para a determinação de políticas públicas voltadas para a capacitação das mulheres para disputarem em igualdade de condições com os homens sua inserção no mercado de trabalho. Na prática social, permite-se que critérios estéticos, raciais, de situação reprodutiva ou de aceitação de assédio sexual determinem o acesso, a permanência ou a promoção das mulheres no mercado de trabalho.

Perseguindo essa ideia de que a sociedade organizada faz e as instituições públicas desfazem ou não asseguram esse fazer, passemos para o movimento negro. O movimento negro ressurge também nos anos 70 influenciado pelos movimentos de minorias que explodiram no mundo naquela época, influenciados pelos movimentos de libertação das nações africanas e pelos movimentos de direitos civis dos negros norte-americanos. Correndo paralelo ao movimento de mulheres, o movimento negro brasileiro demonstra, do ponto de vista organizativo e do ponto de vista de sua visibilidade, os limites impostos pela sociedade à questão do racismo.

O assassinato de um trabalhador negro por policiais militares e a discriminação racial sofrida por dois atletas negros num clube de São Paulo, em 1978, ensejaram um processo de denúncia e organização dos negros contra a impunidade que envolve a questão racial. Tradicionalmente, no Brasil, na luta pelo respeito aos direitos humanos, não se tem dado ênfase ao peso que a violência racial tem na determinação do acesso à justiça e no exercício da cidadania. O negro, conforme relatou o professor Sérgio Adorno, é sistematicamente vítima da violência policial, na qual a tortura é uma prática institucionalizada e marcada por total impunidade. O negro é tido a priori como culpado, o que bem expressa um dos nossos ditos populares: "Negro parado é suspeito, correndo é ladrão”. O folclore com que essas práticas discriminatórias são tratadas presta-se tanto ao ocultamento da tensão racial existente no país, como ao persistente escamoteamento da violação dos direitos de cidadania dos negros brasileiros.

Malgrado essas condições, a ação política do movimento negro, entre outras conquistas, assegurou na Constituição de 88, em seu Artigo 5, Inciso 42, que a prática do racismo constitui crime. Segue-se a esse dispositivo a Lei Complementar 7.716 de 89, do então deputado federal Carlos Alberto Caó, ampliada pelo deputado federal Ibsen Pinheiro através da Lei 8.088 de 1990. Saudadas como um avanço significativo para o futuro das relações raciais no Brasil, essas conquistas constitucionais inspiraram a criação de serviços de assistência legal, como o SOS - Racismo do Geledés - Instituto da Mulher Negra.

Ao iniciarmos o projeto SOS - Racismo, há três anos, realizamos uma pesquisa-piloto em varas criminais de São Paulo para identificar como e quantas vezes a legislação específica sobre o racismo foi aplicada e apurar como se dá o acesso à justiça para os negros. O resultado desse trabalho foi à constatação de que, em 40 anos de existência da Lei Afonso Arinos, raríssimas vezes algum caso de discriminação racial foi objeto de ação penal. Só nos foi possível encontrar dois casos nos arquivos pesquisados em São Paulo. Em três anos de atendimento jurídico a vítimas de discriminação racial, o SOS - Racismo pôde demonstrar à sociedade brasileira e à população negra que a discriminação racial é um fenômeno sistemático, desconhecido da esfera jurídica pela falta de vontade política para o enfrentamento da problemática racial.

Uma das mais constantes dificuldades que temos encontrado nesse atendimento jurídico a vítimas de discriminação racial é que, no momento de lavrar o boletim de ocorrência sobre um ato de discriminação, a vítima encontra no delegado de polícia o primeiro obstáculo para a punição efetiva da prática do racismo. Vários elementos interferem nessa postura da autoridade policial. Primeiro, o descaso com que a discriminação racial é tratada no Brasil, como se fosse assunto irrelevante para o Poder Judiciário. Segundo, a falta de tipificação do crime de racismo no código penal. Terceiro, a tipificação precária existente na legislação especial em vigência relativa ao tema, e a falta de regulamentação do Inciso 42 do Artigo Quinto do capítulo dos Direitos e Garantias Individuais e Coletivos da Constituição. Fundamentalmente, o interesse em desqualificar o crime de racismo, classificando-o como injúria ou difamação, o que é uma maneira de escamotear o grau de incidência da discriminação racial no Brasil, o que fica evidente nas poucas decisões que temos obtido no Poder Judiciário. 
Portanto, a concretização daquilo saudamos como conquistas na Constituição de 1988 se dá na prática social, conforme o caso que relato a seguir. Kelly Cristina da Silva cuidava como babá de dois filhos de Elza, amásia de Rogério César de Almeida. Como, após terminado o serviço contratado, Kelly não recebesse o salário pactuado, dirigiu-se por diversas vezes ao estabelecimento comercial de Rogério, um bar, para conseguir receber o dinheiro que lhe era devido. Passou então Rogério César de Almeida a chamá-la, na presença de frequentadores do referido bar, de negra, negra nojenta, urubu, macaca. Todas as vezes que Kelly Cristina passava pela via pública, em frente ao bar de Rogério, era por esse escarnecida, chamada de urubu, macaca, negra nojenta. A repetição de tais fatos foi tal que até os filhos de Elza e alguns trabalhadores de uma construção vizinha ao bar passaram a dirigir tais ofensas à vítima quando a viam passar. No dia 27 de novembro de 1988, Rogério César de Almeida lavava seu automóvel estacionado em frente ao bar de sua propriedade quando vê passar Kelly Cristina da Silva. Novamente a chama de macaca, urubu, negra. Não satisfeito, com a mangueira da água com que lavava o automóvel dirigiu o jato de água sobre a vítima, molhando-a. Kelly Cristina apelou então a um policial militar que acompanhava a cena e o mesmo encaminhou todos para o Vigésimo Distrito Policial, onde foi dada voz de prisão em flagrante a Rogério César de Almeida, por ter reiterado diante do delegado de plantão os xingamentos a Kelly Cristina.

Manchetes dos jornais da época sobre o caso: "Comerciante é preso por racismo" ( $O$ Estado de S. Paulo); "Racista continua preso" (Diário Popular); "Caso de racismo pode cair no buraco negro" (Diário Popular); "Delegado que autuou comerciante racista foi transferido por autuação"; e finalmente "Solto comerciante racista" (Diário Popular). Vejamos o entendimento do Poder Judiciário sobre o caso. Durante a instrução foram inquiridas as vítimas e três testemunhas de acusação. Em alegações finais, o representante do Ministério Público pediu a absolvição, secundado pelo defensor, porque entendeu que o fato não constitui crime de racismo, embora na sentença admitisse: "Aprova coligida permite concluir-se que em uma oportunidade o réu ofendeu a vítima chamando-a de negra nojenta, macaca e urubu. Mas o digníssimo juiz conclui não ser possível caracterizar o crime de racismo por não haver habitualidade no fato". Perguntamos: quantas vezes temos que ser discriminados para que esse crime seja punido? É ou não é violência levar uma pessoa a rebaixar sua autoestima, humilhar uma menina de 16 anos, criando absoluta dificuldade no seu convívio social? A quem recorrer, se o delegado que ousou transpor essa barreira e autuou o comerciante em flagrante foi relotado para um distrito policial longínquo, como exemplo para os demais?

Em novembro de 93, na Semana da Consciência Negra, o Ministério Público e o Poder Judiciário nos deram outro presente sobre este caso. Em 18/08/93, Monica Aparecida de Oliveira compareceu à agência de empregos Global - Trabalho Temporário Ltda., situada à Rua 24 de maio, onde habilitou-se para uma vaga de auxiliar de escritório na empresa União Química Nature. Foi preterida no cargo por ser negra, fato por ela constatado através da ficha de requisição ali existente. Chamou a Polícia Militar, que compareceu à agência de empregos, tendo o policial militar Isaías Lopes Viana apanhado a ficha de requisição de emprego com a expressa observação de que havia um veto para a contratação de negros. O caso foi levado ao Terceiro DP da capital, tendo se transformado em assunto dos principais órgãos de comunicação de São Paulo. Transformado em inquérito policial, foi relatado em $25 / 08 / 93$ pelo titular do Terceiro DP e enviado ao fórum. Encaminhado ao fórum criminal, o promotor público pediu o arquivamento do processo sem oferecer denúncia por falta de prova material, acompanhado nesse parecer pelo juiz de direito. De nosso ponto de vista, esse entendimento do promotor impediu que se esgotasse todas as possibilidades de investigação, não permitindo qualquer diligência a fim de elucidar os fatos. O parecer do Ministério Público, bem como a decisão proferida pelo juiz, não levaram em consideração as provas existentes nos autos, documentos referentes à ficha de solicitação de emprego, testemunho do policial militar que atendeu a ocorrência e pôde verificar a ficha discriminatória, além das declarações da vítima, elemento de fundamental importância para o encaminhamento da causa, o que nos leva a crer que a decisão proferida foi contrária às provas existentes. Na maioria dos delitos praticados em nossa sociedade, quando há presença de policiais ou esses são acionados e levados à justiça, o testemunho dessa autoridade para a decisão do caso é fundamental. No entanto, no presente caso, o Ministério Público e o Poder Judiciário sequer levaram em consideração o fato de a prova material ter sido vistoriada pelo policial militar que atestou em todos os seus depoimentos a existência da exigência de cor branca para admissão naquela empresa.

Decisões como essa atestam que a prática da discriminação racial é tratada com absoluto descaso pela sociedade, pelos delegados de polícia, pelos advogados, promotores e finalmente pelos juízes. O Ministério Público e o Poder Judiciário têm que abandonar sua histórica omissão em relação aos interesses e necessidades dos segmentos discriminados e marginalizados da sociedade. 
Precisamos romper com o paradigma de que o código civil é para os ricos e o código penal é para os pobres, ou, conforme sentimos nós negros, que o código civil é para os brancos e o código penal para os negros.

A impunidade com que são tratados os casos de discriminação de raça e de gênero reitera a ideia de que a cidadania só pode ser exercida por um indivíduo que atender a quatro condições: seja macho, branco, rico e heterossexual. Precisamos aprimorar conceitos, precisamos de serviços jurídicos que correspondam à expectativa da sociedade, que se preocupe com suas peculiaridades. A isso o Estado, especialmente o Ministério Público, tem se mostrado insensível ou ineficaz. O que temos encontrado são dificuldades no acesso à justiça, às regalias da lei no tocante à punição dos agressores, principalmente nas questões de raça e de gênero. A sociedade civil e os segmentos discriminados fazem a sua parte, denunciam, se organizam, reivindicam, alcançam conquistas no plano legal, mas essas conquistas esbarram na falta de vontade política das instituições jurídicas para efetivá-las. Porém, a inoperância dessas instituições jurídicas tem incrementado também o desenvolvimento na população de ações organizadas nitidamente antissociais, como os linchamentos, a ação dos justiceiros, a defesa da pena de morte, o extermínio de crianças, a ação de grupos neonazistas. Barbárie ou civilização? Eis a questão, eis o desafio.

\section{Floriza Verucci}

Depois desta brilhante exposição de Sueli Carneiro, que evidenciou de maneira claríssima o afastamento dos órgãos da justiça em relação à realidade social, e que complementa também a exposição do professor Sérgio Adorno, passo a palavra ao professor Celso Campilongo.

\section{Celso Campilongo}

Em primeiro lugar, gostaria de agradecer ao IDESP pelo convite e pela oportunidade de participar deste seminário. Vou dividir minha exposição em três momentos. Primeiro, um breve enquadramento teórico desses problemas do acesso à justiça; segundo, análise de alguns dados, tanto da pesquisa do IDESP quanto de outras pesquisas, com o objetivo de problematizá-los; e, finalmente, uma indicação de quais são, a meu ver, os principais desafios no tocante ao acesso à justiça. Portanto, um misto de diagnóstico da situação presente com um prognóstico para os próximos anos.
Do ponto de vista teórico, se tivéssemos que estabelecer uma comparação entre os problemas de acesso à justiça nos países centrais ou nos países do mundo desenvolvido, onde o Estado de Bem-Estar Social se acha relativamente consolidado, com países como o Brasil, onde o Estado é talvez assistencial, um Estado da semiperiferia do sistema internacional poderíamos dizer que, nos países centrais, o acesso à justiça é, sobretudo, um problema de garantia de acesso para minorias. Entre nós, como ficou evidenciado pelas duas exposições que acabamos de ouvir, o problema do acesso à justiça é indiscutivelmente um problema das maiorias. A esmagadora maioria da população de um país como o Brasil não tem acesso à justiça.

Nos países centrais, a contextualização do acesso à justiça vem precedida por um processo histórico e cumulativo de afirmação da eficácia dos direitos: em primeiro lugar, os direitos civis ou individuais; em segundo lugar, os direitos políticos; e, finalmente, os direitos sociais. Uma sequência, cada uma dessas etapas sendo precedida de uma relativa consolidação da eficácia da etapa anterior. Entre nós, o processo se dá de uma forma completamente diversa. Nós tentamos simultaneamente, na mesma conjuntura histórica, afirmar tanto os direitos civis e individuais quanto os direitos políticos, os direitos sociais e os coletivos. Ou seja, os desafios para o acesso à justiça entre nós são infinitamente mais acentuados.

Em terceiro lugar, nos países centrais, a preocupação com o acesso à justiça é principalmente com a manutenção de um certo padrão de garantia dos direitos, de eficácia e de penetração dos direitos na sociedade. Ora, entre nós, a preocupação com o acesso à justiça não é de manutenção, mas sim de obtenção de algo que nunca foi conquistado: a afirmação da cidadania pela via judicial.

Por fim, do ponto de vista sócio-jurídico, poderíamos dizer que a relação entre forças sociais e eficácia do direito nos países centrais se dá aproximadamente da seguinte forma: uma sociedade suficientemente organizada para conquistar avanços legislativos e, mais do que isso, para fazer com que avanços legislativos tenham eficácia prática, que a lei seja eficaz e aplicável em todas as esferas e principalmente na esfera judicial.

Entre nós, o que parece ocorrer é que a sociedade atingiu um grau de organização capaz de obter determinados avanços legislativos. E o caso da Constituição, da legislação a respeito de interesses difusos, do código de defesa do consumidor. Ou seja, em diversos diplomas legais, podemos perceber que a sociedade brasileira foi suficientemente organizada para conseguir o avanço 
legislativo. Entretanto, não conseguiu dar o segundo passo. Sua organização não é capaz de fazer com que essa legislação seja respeitada.

Isso tudo é muito sumário. Poderíamos, evidentemente, discutir cada um desses conceitos de forma mais aprofundada, mas gostaria de examinar agora alguns dados de pesquisas para ilustrar as dificuldades do acesso à justiça no caso brasileiro. O primeiro dado vem de uma pesquisa do IBGE, que diz que $55 \%$ dos conflitos jurídicos em que brasileiros se envolveram durante um determinado período, ou seja, a maioria desses conflitos, não foi resolvida com a intervenção de advogados e muito menos com a intervenção do Poder Judiciário. Diz a mesma pesquisa: $65 \%$ dos entrevistados não confiam nem nos serviços jurídicos e nem nos serviços judiciais.

Comparando esses dados com os de outras pesquisas, começamos a perceber alguns paradoxos. Eu tive a oportunidade de participar, em 1990, de uma pesquisa em São Bernardo do Campo: uma pesquisa a respeito do perfil sociopolítico e sócio-jurídico de usuários e de advogados que trabalhavam nos grupos de assessoria gratuita à população com menos recursos econômicos na comarca de São Bernardo do Campo. Fizemos um mapeamento de todos os grupos de assessoria jurídica gratuita naquela cidade. Chegamos a alguns dados que nos permitem relativizar os dados do IBGE. Para nosso espanto, dentre os usuários daqueles serviços, ou seja, a população carente que procura o acesso à justiça ou pelo menos um acesso ao Judiciário, apenas $8 \%$ dos entrevistados consideraram os serviços ruins ou regulares, $67 \%$ dos entrevistados consideraram os serviços de assessoria jurídica gratuita muito bons e $24 \%$ consideraram esses serviços excelentes. A pesquisa revelou também que esses grupos atendiam em média 50 pessoas por dia. Dessas 50 pessoas atendidas diariamente, nos núcleos de assessoria jurídica, a grande maioria vinha ao serviço pela primeira vez. Ora, quem tem a mais pálida ideia do que é um escritório de advocacia, de como funciona o serviço de advocacia, sabe que é absolutamente impossível, a não ser que você tenha uma estrutura de atendimento quase industrial, o que não é o caso desses serviços de assessoria jurídica, alguns dos quais não tinham sequer microcomputador, fazer um atendimento adequado da população. Com o instrumental desses centros de assessoria jurídica, é absolutamente impossível. Há uma completa incompatibilidade entre o ritmo do serviço judicial e um atendimento para um número tão elevado de demandas. De outro lado, se esses serviços são procurados com tal intensidade, chegamos a um total de 4.000 atendimentos por mês, isso significa que existe uma demanda acentuada por serviços jurídicos e judiciais, pelo menos naquele contexto. Portanto, diferentemente dos dados obtidos pelo IBGE, há certa crença de que o Judiciário e os advogados podem resolver esses problemas.

Vejam como esses dados vão nos conduzindo a alguns paradoxos. Vejamos agora um dado da pesquisa do IDESP, que está na tabela 14: a questão da compatibilidade ou não entre o direito atual e certos objetivos substantivos. Com relação aos direitos coletivos, aqui incluídos o direito do consumidor e o direito dos aposentados, $58 \%$ dos juízes entrevistados consideraram que existe compatibilidade entre esses direitos e os objetivos substantivos da justiça. Ora, eu tenho a oportunidade de trabalhar num centro de estudos de direito sanitário, que poderíamos incluir no rol dos direitos coletivos, o direito à saúde. Curiosamente, dentre os juízes muitas vezes convidados para participar das atividades desse centro e em pesquisas realizadas de maneira informal nesse centro, eu diria que a maioria dos juízes tem uma sensibilidade quase nula a respeito do problema do direito à saúde. Alguns dizem que o direito à saúde não é passível de enquadramento pela via judicial, que tem que ser resolvido junto ao Executivo, que é um problema de políticas públicas, ou ainda que o Judiciário não está aparelhado para enfrentar esse tipo de litigância. Então, eu pergunto: se os juízes se posicionam dessa maneira perante o direito à saúde, como é possível que $58 \%$ digam que existe essa compatibilidade?

Vejamos, na mesma tabela 14, a questão dos direitos difusos e do meio ambiente. Aqui a resposta desce para $45.6 \%$. Eu conheço pelo menos uma pesquisa que estudou todos os casos, durante um determinado período, de ações judiciais sobre o tema meio ambiente no município de Cubatão. Essa pesquisa demonstra, primeiro, que os casos não eram tão numerosos, apesar de muito importantes: eram sete ou oito casos no período estudado, e desses casos nenhum chegou a qualquer conclusão, pelo menos durante o período da pesquisa, e alguns processos já caminhavam há mais de dez anos. Como, então, afirmar a compatibilidade do direito com certos objetivos substantivos, em percentuais tão elevados? Os dados de que tenho conhecimento, e não existem muitas pesquisas sobre esse aspecto, não levam a essa conclusão: é o caso de uma tese de mestrado defendida na Faculdade de Direito da USP pela professora Maria Cecília MacDowell.

Por fim, a questão da compatibilidade entre o direito atual e certos objetivos dos setores menos privilegiados. Aí a compatibilidade decresce bastante. Apenas $38.9 \%$ dos entrevistados dizem que essa compatibilidade existe. E aqui, novamente, tenho uma dificuldade em conciliar os dados da pesquisa do IBGE, de São Bernardo do Campo, e os do IDESP. Alguns, como a descrença da população 
no acesso à justiça são compatíveis. Mas a expectativa positiva com relação aos serviços de assistência judiciária em São Bernardo do Campo é incompatível com esses números. Em São Bernardo do Campo, $67 \%$ dos entrevistados achavam que os serviços eram bons. Mas havia restrições ao serviço de assistência judiciária entre advogados e juízes: advogados que perdiam prazos, advogados que não tinham recursos materiais para acompanhar as ações, estudantes despreparados para a assistência judiciária. Apesar disso, a população entendia que aqueles serviços eram razoáveis.

A partir do arcabouço teórico e dos dados que acabo de expor, gostaria de apresentar algumas hipóteses sobre os desafios a serem enfrentados pelo Judiciário no tema do acesso à justiça. De um lado, nós podemos dizer que a sociedade brasileira vive um processo de desinstitucionalização do conflito. Ou seja, parte dos conflitos está sendo encaminhada de forma diferente daquela que tradicionalmente concebemos. A institucionalidade, isto é, o Judiciário como leito institucional para a composição de conflitos e a lei como a medida dessa composição estão sofrendo um baque muito grande. A maioria dos conflitos jurídicos não vem sendo resolvida através da intervenção do Judiciário ou através da intervenção de advogados, mas por outras formas.

Mas, de outro lado, e aí está o paradoxo, talvez nunca o Judiciário tenha assumido uma importância tão grande na sociedade brasileira quanto hoje. As pessoas demandam com mais intensidade e confiam cada vez mais as suas esperanças à justiça. Nos dados da pesquisa de São Bernardo do Campo, o número de clientes dos grupos da assessoria jurídica ilustra esse fato. Nunca o Judiciário e os serviços jurídicos, de maneira geral, foram tão procurados. Ora, se o conflito social moderno é um conflito em torno da ampliação ou restrição de direitos, se de um lado há uma desinstitucionalização da conflituosidade e de outro lado uma procura mais intensa do Judiciário, a hipótese que eu levanto é que o Judiciário precisa oferecer novas respostas a essa conflituosidade que se resolve diferente da do Direito tradicional. Os problemas de acesso à justiça tendem a aumentar de importância nos próximos anos.

Gostaria de apontar alguns desses problemas. Primeiro, o problema da desinstitucionalização do conflito combinada com o aumento do recurso ao poder judiciário. Isso significa, do ponto de vista do Judiciário, ou do ponto de vista do Estado, que precisamos compreender e equacionar essa situação de ruptura do monopólio estatal da produção do direito. A maioria das sociedades contemporâneas convive com outras formas de produção do direito. Quais são as implicações desse fato, na perspectiva do acesso à justiça? As construções teóricas disponíveis sobre esta questão não são numerosas, embora sejam qualitativamente expressivas. E ainda há, do ponto de vista institucional, certa resistência, para não dizer quase um desprezo com preocupações dessa natureza.

Em segundo lugar, vivemos hoje um período de ajuste da economia internacional, um impacto liberalizante, que leva a uma revisão do papel do Estado na economia e na regulação da vida social. Não apenas no Brasil, mas também entre nós, existe um processo de deslegalização e de desregulamentação de atividades sociais. Isso vai da economia aos direitos sociais. No debate sobre a revisão constitucional, existem propostas de enxugamento dos direitos sociais, ou seja, de deslegalização e desregulamentação desses direitos. O instrumento por excelência de atuação do Judiciário, na perspectiva tradicional, é a legalidade; mas se estamos passando a uma legalidade atenuada, a um processo de deslegalização e de desinstitucionalização dos conflitos, como fica a posição do Judiciário?

Em terceiro lugar, ainda na onda do impacto do neoliberalismo sobre o Judiciário e o acesso à justiça, vivemos também um processo de delegação do Estado para a sociedade de uma série de capacidades decisórias. Tome-se como exemplo o que aconteceu há dois ou três anos, no tocante às mensalidades escolares. Ao invés de o Estado dizer que a mensalidade escolar iria ser aumentada em tantos por cento, e essa é uma manifestação da soberania estatal, o Estado delega para a sociedade, de maneira aparentemente até mais democrática e participativa, a capacidade decisória. Assembleias reunindo proprietários de escolas e alunos ou pais de alunos vão decidir essas questões. Também no campo do direito do trabalho ocorre uma delegação do Estado para a sociedade. E, da mesma forma, no tocante aos direitos humanos. A declaração de direitos humanos de Viena, por exemplo, atribui não ao Estado, mas à sociedade civil uma importância fundamental na vigilância, na eficácia e no policiamento do respeito aos direitos humanos. Há um processo de delegação nesse caso também.

Como lidar com essa desinstitucionalização do conflito, ou pelo menos essa reconfiguração da conflituosidade e dos mecanismos de enquadramento da conflituosidade jurídica? Como trazer essa conflituosidade delegada para a sociedade, a respeito da qual o Estado abre mão, para o interior do Judiciário? Qual será a postura do Judiciário diante desse processo de delegação do Estado para a sociedade civil de competências decisórias? De outro lado, há também certa desterritorialização da legalidade, que equivale a uma relativização do próprio conceito de Estado. Surge uma legalidade que nem sempre está apegada ao limite 
geográfico do Estado, uma legalidade circunstancial, regionalizada, municipalizada ou voltada para determinados setores, como a legalidade construída nas relações de trabalho, no interior da fábrica ou no seio dos movimentos sociais. Há um processo de desterritorialização da legalidade. Como lidar com essa tendência? Eis aí um desafio para o judiciário.

De outro lado, há também o surgimento de novas arenas ou novos espaços de conflito, que vão muito além do conflito entre capital e trabalho, ou do conflito no direito da família. No estudo que fizemos em São Bernardo, constatamos que havia uma demanda maior nos serviços de assessoria jurídica gratuita exatamente nesses setores: direito da família e direito do trabalho. Paralelamente a essa conflituosidade tradicional, começa a ganhar espaço uma conflituosidade com outro perfil, a dos direitos sociais, das políticas públicas. Dessa nova conflituosidade são portadores também atores sociais distintos, particularmente os movimentos sociais. Que relação se pode estabelecer entre movimentos sociais e Poder Judiciário? Em que medida o Poder Judiciário legitima a atuação dos movimentos sociais e é simultaneamente também legitimado por esses movimentos na medida em que o procuram?

Para finalizar, gostaria de dizer alguma coisa sobre a nova concepção de cidadania. O Judiciário trabalha tradicionalmente com uma concepção de cidadania regulada pelo Estado, pela legislação estatal. Mas, cada vez mais, o debate jurídico toma contato com a cidadania desregulada, uma cidadania que se constrói à margem do direito estatal, ou que se esforça para obter a garantia de direitos por caminhos que nem sempre se ajustam exatamente àquilo que está literalmente escrito no direito estatal. Como essa nova forma de construção, de afirmação da cidadania pode ter acesso ao Poder Judiciário? Como se vê, estamos diante de problemas muito árduos, de difícil solução, sobre os quais devemos refletir, tendo em vista o aperfeiçoamento do acesso à justiça.

\section{Floriza Verucci}

Muito obrigada, professor Campilongo. Passo a palavra em seguida ao professor Joaquim Falcão.

\section{Joaquim Falcão}

o que vou dizer toma como base duas vertentes de minha experiência profissional: uma voltada para pesquisas que fiz sobre invasões urbanas e direito de propriedade em Pernambuco, na década de 70, e que estou agora prosseguindo, na favela da Rocinha no Rio de Janeiro; e outra vertente que compartilhei, com muita honra para mim, com Bolívar Lamounier e com Floriza Verucci, na comissão Afonso Arinos, em 1985-1986. Nessa segunda vertente, minha preocupação não era sobre como a sociedade equaciona seus conflitos - como pensei na pesquisa de Pernambuco e estou pensando na do Rio de Janeiro -, mas como o Estado, através da Constituição, enfrenta essa questão de equacionar conflitos e implementar a justiça.

Dividirei a minha exposição em três partes. Primeiro, vou especificar a questão que me parece principal no Brasil sobre o acesso à justiça; em seguida, darei algumas indicações teóricas de como enfrento essa questão; e, em terceiro lugar, sugerirei uma estratégia de ação para enfrentá-la.

Quando se fala de acesso à justiça, temos basicamente dois enfoques. Um enfoque é como aperfeiçoar o modelo existente de administração da justiça. Sob esta ótica, discutimos o elitismo do aparelho judiciário, a questão do racismo, a ineficiência do aparelho judiciário, e assim por diante. Ou seja, nessa ótica a ênfase não recai sobre a justiça, e sim sobre o Judiciário. Segmentamos a questão para focalizar o Estado: a modernização da justiça, a criação de novas varas, a oferta de novos tipos de justiça, a remuneração dos juízes, a revisão do direito processual, etc. Nessa vertente, a questão se transforma numa questão de organograma do Estado, numa questão de recursos e, em última análise, de mudança administrativa. Essa é a vertente predominante no debate público.

Assim formulada, a questão do acesso à justiça tem como pressuposto a ideia do monopólio da administração da justiça pelo Estado. Como se caracteriza esse monopólio? De diversas formas. Uma é pela profissionalização. A OAB fez questão de incluir na nova Constituição um artigo dizendo que o advogado é indispensável à administração da justiça. É a profissionalização, a concepção de que justiça é apenas justiça estatal e de que o direito é lei. Ou seja, existem vários fatores, tanto teóricos como práticos, que transformam a discussão sobre como conseguir mais acesso para determinados grupos sociais ao aparelho da justiça, numa forma de reforço à concepção do monopólio estatal da administração da justiça. Mas quando tentamos ver as coisas de baixo para cima - quando vamos a Rocinha, às favelas do Skylab do Recife e outras-, vemos um universo completamente diferente. Vemos que a questão do monopólio estatal da justiça está presente, mas não é a questão prioritária. Somos forçados a repensar, na prática, toda a discussão, e vemos que não se trata exatamente do Judiciário, mas da justiça. Se conseguíssemos desfazer a sinonímia de que acesso à justiça 
significa acesso ao Judiciário, ampliaríamos o alcance desse debate e contribuiríamos, provavelmente, para a formulação de soluções mais adequadas. Este enfoque é diferente daquele que predomina no debate público, inclusive nas propostas de revisão constitucional e de reforma do Judiciário, que são lideradas em grande parte pela OAB e pelo próprio judiciário. Dizendo-o de outro modo, precisamos ressaltar a insuficiência dessa estratégia centrada no conceito de modernização do Judiciário e repensar a questão do monopólio estatal da administração da justiça.

Entrando na segunda parte, gostaria de fazer três observações. Um autor alemão, Niklas Luhmann, diz que a justiça só será legítima, só será uma justiça aceita pela sociedade, se cumprir três etapas. Primeiro, se ela for capaz de produzir decisões. Segundo, se for capaz de implementar tais decisões, ou seja, se conseguir que a sociedade aceite as decisões que toma. Terceiro, se essas decisões produzidas e implementadas pela justiça forem realmente capazes de resolver, ou pelo menos amortecer e equacionar os conflitos sociais.

Não creio que seja necessário exemplificar, mas basta observar, no caso brasileiro, as dificuldades que o Supremo Tribunal Federal tem encontrado para decidir questões referentes a índices de reajustes, porque, se aplicar as decisões a que é cultural e ideologicamente induzido, causa sérios danos à economia e aumenta o conflito social. Esta é outra face da lentidão da justiça, sobretudo da lentidão do Supremo: a percepção que os juízes têm de que, ao aplicar as leis vigentes, dentro do esquema conceitual da dogmática clássica, tendem a perder legitimidade, talvez de uma forma extremamente grave para o sistema institucional como um todo.

Minha segunda observação conceitual complementa e explicita uma anotação do Bolívar Lamounier que me tem sido muito útil, por causa da minha formação majorística. Em nossa área, quando falamos de legitimidade, falamos de consenso sobre valores, de aceitação de instituições, etc. O Bolívar tem mencionado a dimensão da experiência como um componente indispensável para a concepção de legitimidade. Ou seja, não basta o povo querer justiça, é preciso que essa justiça se transforme numa experiência cotidiana através de decisões que afetem e regulamentem sua vida. Vejo na maioria das pesquisas sobre este tema o seguinte paradoxo: uma adesão ao valor justiça, ao valor juiz, ao valor advogado, ao valor procedimentos previsíveis, mas ao mesmo tempo uma experiência desesperada, onde se nega isso tudo. A realidade não é uma coisa ou outra, é ambas. É verdade que o cidadão quer o Judiciário, e também é verdade que não experimenta o Judiciário. Quer o direito da lei, mas não experimenta o direito da lei. E é com essa contradição que eu lido.

Essa contradição é ilustrada de maneira notável por uma frase colhida na pesquisa que fizemos em Pernambuco. Perguntamos a uma ocupante de um terreno: "A senhora acha direito invadir terreno de outro?". Ela disse: "Se é direito não sei, mas que eu fiz direito, fiz". Essa é a situação, e é ela que nos leva a essa conclusão aparentemente paradoxal: precisamos pensar não somente em aumentar o acesso à justiça, mas também diminuir o acesso à justiça. Precisamos pensar na relação entre a demanda e a oferta. Se a oferta diminui ou, de qualquer modo, se permanece insuficiente, como fazer com que o judiciário ganhe legitimidade? Ou ele se abre para as demandas ou administra o acesso a essas demandas. Nessa linha de raciocínio, estamos falando de uma situação em que o Judiciário está em concorrência com outras "arenas" ou instâncias. É importante ter essa noção de concorrência, porque os juízes em geral não têm, os advogados não têm e muitas vezes as pesquisas sobre o judiciário têm como objetivo implícito abrir as portas da Justiça, sem perceber que hoje em dia essa é uma das estratégias, mas não a única.

Chego, assim, à terceira parte, à questão do monopólio. O que caracteriza hoje o monopólio da administração da justiça pelo Estado? Acho que a resposta a esta indagação se desdobra em três dimensões. A primeira é a dimensão profissional. Na pesquisa do IDESP, os juízes dizem que a segunda entre as causas da morosidade da justiça é o interesse dos advogados, a primeira é o alto número de recursos. Estes são fatores que, ao ver dos entrevistados, obstaculizam o bom funcionamento do Judiciário: o excesso de formalidades nos procedimentos judiciais, o elevado número de litígios, o despreparo dos advogados e processos irrelevantes. Pergunto-me se não é por essa razão que, na fase judicial, os réus negam o que confessaram: é porque o interesse do advogado é que ele negue. E é por isso que interpreto certas propostas de revisão constitucional com controle do Judiciário como propostas de pacto entre os profissionais interessados em manter o atual modelo. O modelo implícito em tais propostas não leva em conta a participação da sociedade, de administradores, enfim, de experts de outras áreas. $\mathrm{O}$ pacto a que me refiro acaba amortecendo algumas questões fundamentais. Por exemplo, quando se fala em corrupção do Judiciário: a questão não é se a sentença tal foi proferida de maneira corrupta, se houve tal ou qual influência indevida; não, essa não é a corrupção que afeta o cidadão comum. O que interessa à maioria dos brasileiros é a corrupção do preparo, é a corrupção da taxa, é a corrupção do oficial de justiça. Essa é a corrupção disseminada. O pacto profissional a que aludi 
está fundamentado nesse modelo, e essa, como disse, é a primeira dimensão da questão do monopólio administração da Justiça pelo Estado.

Posso dar outros exemplos. Participei de uma pesquisa comparativa de 11 países, com o Richard Able, na Universidade da Califórnia, sobre o que é o advogado no Japão, na Venezuela, no Brasil, entre outros. Em nome de que é preciso ter advogado para fazer divórcio? Se para casar eu não preciso de advogado, por que preciso de advogado para me divorciar? Mas há uma lei que diz que é preciso, e a lei é feita pelo Estado. É porque existe o problema dos filhos. E se não houver filhos? Dirão que é a existência de um conflito. E se não houver conflito? A verdade é que há envolvidos em todo esse processo.

Alguém já disse que os advogados são os pastores da liberdade, mas são também os arautos da ditadura. Estão ao lado do Estado como estão ao lado da sociedade. Então o que caracteriza hoje em dia o advogado é esse "mix" do qual eles são excelentes "managers".

A segunda dimensão a que me referi na questão do monopólio estatal da justiça é a dimensão técnico-jurídica ou doutrinária. Os interesses a que me referi, que ora são específicos, profissionais, ora são mais amplos, se traduzem em doutrinas e técnicas. O que está em jogo, muitas vezes, sob a capa do discurso técnico, é a centralização do sistema, é o controle do sistema. Muitas das propostas de revisão constitucional e reforma do judiciário visam, na verdade, fortalecer o sistema, fortalecendo seu núcleo gestor, o Supremo Tribunal. Ou seja, além do pacto profissional, existe uma cobertura técnico-doutrinária, um conjunto de preceitos, instituições e procedimentos, que se apresentam como falas de doutos, como doutrinas, ao que tudo indica com a intenção implícita de dificultar a compreensão do sistema pelo leigo.

A terceira e última dimensão do monopólio do Estado é o pacto entre os três poderes: Executivo, Legislativo e Judiciário. Eles são os gestores das normas, da riqueza e da força. Podem até alimentar divergências entre si, desde que não entre mais ninguém no sistema. O Roberto Mangabeira Unger tem tentado mostrar que essa é a questão implícita na noção de checks and balances, isto é, na noção de três poderes independentes entre si. O que ocorre quando esses três poderes entram em conflito? A doutrina do checks and balances diz que um controla o outro. Que quer dizer isso? Ora, quer dizer que o jogo do poder fica entre eles, reforçando, portanto, a concepção do monopólio estatal.
Concluindo, quero dizer que meu objetivo é repensar a relação entre o Estado e a Sociedade nesse âmbito específico que é a administração da justiça. Na Rocinha, os cidadãos querem o Judiciário. Não é aquela visão ingênua de que agora vai ser a justiça comunitária da comunidade, a Rocinha vai se autogerir, vai fazer isso e aquilo. Não, o que eles querem é outro relacionamento entre a justiça que está lá dentro e a que está lá fora, e isso inclui a desprofissionalização e a delegação, entre outros aspectos. Por exemplo: a Rocinha pega um contrato de compra e venda, desses de cartório. Lá está escrito que o ocupante tem que sair da casa, porque alguém a comprou, no prazo de três ou seis meses, como mandam as cláusulas da compra e venda. O que acontece? Se no final de três meses o ocupante diz que não tem para onde ir, o consenso da Rocinha é que esse "não ter para onde ir" é mais importante do que a cláusula escrita no contrato. Então, é necessário que se estabeleça um novo "mix" entre procedimentos que são necessários na ótica da justiça do Judiciário e outros que decorrem dessa justiça local. Até porque esse consenso inclui o comprador, porque se não aceitar esse consenso comunitário ele se deslegitima até para morar ali.

Permitam-me frisar que não desconheço a importância da justiça estatal. $\mathrm{O}$ Celso Campilongo falou em desinstitucionalização, eu falaria em reinstitucionalização, mas acho que, no fundamental, não estamos em desacordo. E precisamos de um ajuste processual. Com o direito processual vigente, é impossível repensar a fundo estas questões. Como os senhores sabem, passei por Olinda, de onde sou, antes de vir do Rio de Janeiro para São Paulo e por isso concluo com uma frase do Tobias Barreto: a pior forma de injustiça é ser injusto e parecer justo.

\section{Debate}

\section{Floriza Verucci}

Temos aqui representantes da magistratura, do Ministério Público, dos advogados, da universidade, pessoas de vários Estados e tenho certeza que tiraremos deste debate conclusões muito importantes sobre a questão do acesso à justiça. A palavra está livre para quem quiser se manifestar com perguntas e comentários.

\section{Sílvio Vianna}

Senhores participantes da mesa de debates, em nome da Associação dos Magistrados do Estado de Rondônia, em primeiro lugar gostaria de manifestar as congratulações pelo trabalho que o IDESP está desenvolvendo, trabalho realmente 
inédito, e manifestar também que nós, magistrados, que obviamente não estamos apáticos nesse debate, gostaríamos de participar ativamente dele e prestar, também nesse âmbito de atuação e de discussão, a nossa colaboração.

Minha pergunta é dirigida ao Dr. Sérgio Adorno, com relação à discussão e à pesquisa realizada aqui em São Paulo, sobre a questão sociológica do acesso à justiça por parte das populações de baixa renda. Minha pergunta é: como poderia o Poder Judiciário, que se situa numa posição estática no sentido de concretizar o direito e torná-lo lei relativamente às partes, efetivamente buscar no âmbito sociológico indicações sobre essas mudanças sociais que estão eclodindo atualmente?

\section{Sérgio Adorno}

Minhas reflexões partem dos resultados de minha pesquisa. Os primeiros resultados, como disse, indicam que há uma desigualdade de acesso à justiça e que isso provavelmente se vincula a uma distribuição desigual das sentenças para brancos e negros. Com relação às garantias processuais e aos direitos, parece-me que as garantias não são de fato iguais, porque muitas vezes os advogados não exploram o potencial, os espaços da lei. Conversei várias vezes com magistrados e representantes do ministério público. Eles em geral não concordam com a minha conclusão, mas a mim me parece que o advogado dativo se empenha menos na defesa do réu que o advogado constituído. Em geral, a julgar pelos processos, as defesas dos advogados dativos são muito curtas, muito sintéticas, e raramente exploram a hermenêutica ou pesquisam situações idênticas que possam argumentar a favor do réu. Em geral, o advogado dativo é muito objetivo, muito restritivo, muito técnico, nos termos da lei. O advogado constituído em geral faz o contrário: pesquisa, argumenta, vai atrás das informações.

Lembro-me de um caso muito interessante, no qual se achava envolvido um advogado constituído. $\mathrm{O}$ processo estava correndo à revelia e quase no final do processo o réu compareceu. Que fez o advogado de defesa? Pediu o atestado de antecedentes do réu e da vítima. Quando veio o atestado de antecedentes da vítima, era uma bela carreira criminal, com estupro, assalto, etc. Ele então inverteu as posições, transformou o réu em vítima e a vítima em réu. O desfecho do processo foi a absolvição. Essa justamente é uma estratégia. Os tribunais, na verdade, estão num embate entre a defensoria e a acusação e, evidentemente, quem reúne as melhores provas acaba obtendo decisões favoráveis.
O problema é que o acesso aos serviços de defensoria não é universal e igual. Não sei dizer como esse problema poderia ser resolvido, se devemos ou não ampliar esses serviços. Referindo-me à instigante exposição do Joaquim Falcão, gostaria de lembrar que muitas das questões aqui suscitadas não valem para a justiça penal. A justiça penal é menos vulnerável ao tipo de conflituosidade que aparece, por exemplo, nos casos de invasão de terra ou em questões civis.

Do ponto de vista sociológico, uma questão importante diz respeito à formação dos magistrados. Cada vez mais essa formação é puramente técnica, como se a lei fosse uma espécie de redoma, e o magistrado, para garantir a sua neutralidade, não se envolve com o entorno social e político. Essa visão está cada vez mais sendo colocada em causa, especialmente no caso da justiça penal. É muito difícil um juiz julgar apenas com base nos processos, sem levar em consideração, por exemplo, o momento histórico e as circunstâncias, ou seja, sem recorrer a uma avaliação propriamente sociológica. É evidente que há um perigo aqui, que é confundir uma avaliação de tipo sociológico com argumentos de ordem pessoal e moral.

É preciso promover o diálogo entre os magistrados e outros membros da sociedade, e, neste sentido, esta é uma oportunidade ímpar. Quando converso com os magistrados, percebo que eles sentem muito essa necessidade de diálogo, que eles também estão muito incomodados com o fato de que têm uma responsabilidade difícil de ser satisfatoriamente cumprida, nas condições atuais. Se conseguirmos aumentar esse intercâmbio, poderemos entender melhor o ponto de vista dos magistrados e, ao mesmo tempo, contribuir para que os magistrados possam reexaminar suas visões de mundo, suas concepções e suas práticas.

Outro caminho é o sugerido, entre outros, pelo Celso Campilongo e pelo José Eduardo Faria: mudar a formação dos advogados e dos futuros magistrados, propiciando-lhes uma formação mais ampla, menos tecnicista, menos formalista, que dê ao futuro juiz uma compreensão da função política e social implícita no ato de julgar.

Quanto ao monopólio estatal da administração de justiça, parece-me que ele hoje cria mais problemas do que resolve. Sobretudo no plano do direito de punir, a soberania do magistrado parece-me hoje questionável. Deveríamos talvez pensar numa maior presença da sociedade, uma maior vigilância da sociedade, não no sentido de cobrar posturas profissionais, mas de saber que o magistrado está na verdade exercendo uma função para a sociedade, está decidindo o destino das pessoas. Pensar, portanto, num contato mais estreito entre a sociedade civil e o Estado. 


\section{Ivana Farina}

Sou presidente da Associação Goiana do Ministério Público. Inicialmente quero cumprimentar a mesa e registrar, mais do que minha satisfação, a necessidade que sinto, como representante do Ministério Público, de participar de um debate desta natureza. Não só pelo nível do que vem sendo transmitido pelos palestrantes, mas também pela possibilidade de interação entre aqueles que são comprometidos com o justo e que por muitas vezes são fragilizados por não estarem juntos, porque o debate está centralizado na esfera de competência de cada um.

Gostaria de fazer uma pergunta ao professor Sérgio Adorno, tendo em vista a sua pesquisa, referindo-me a um ponto dela que frequentemente é debatido no âmbito do Ministério Público e do Judiciário. Com referência à indagação sobre a incidência da condenação entre cidadãos brancos e cidadãos negros, eu gostaria de saber se a pesquisa leva em conta a questão da impunidade.

Digo por que. Embora nem sempre se reconheça isso, é mister admitir que é muito mais fácil condenar o pobre, o negro, o marginalizado, porque ele está realmente sem nenhum acobertamento das provas. Ali, não há estrutura nenhuma para protegê-lo. Ele é denunciado, é processado, e vai ter realmente uma defesa mais frágil. E por isso tende a ser condenado e preso. Minha indagação, portanto, é se a pesquisa já traz embutido esse aspecto. Se não estiver, vai aqui uma sugestão, porque é um fato que nos incomoda (e acho que nos deve incomodar mesmo).

\section{Sérgio Adorno}

A pergunta é muito pertinente e ao mesmo tempo muito perturbadora. Não foi possível fazer o que a senhora sugere e a razão é óbvia. Na verdade, são questões correlatas, acho que a senhora tem absoluta razão na sua formulação, mas do ponto de vista da pesquisa eu teria que ter feito o seguinte: teria que comparar todos os casos, por exemplo, de ocorrência criminal que são efetivamente processados e aqueles que acabam não sendo processados. Tenho alguns estudos que mostram isso, mas nessa pesquisa teria que ter feito um acompanhamento diferente. Como meu objeto era o resultado da sentença, não me ocupei da questão da impunidade. Acho que é uma questão, relevante, mas nesse momento tive que fazer um corte e nesse corte não pude considerá-la.

Não obstante, gostaria de dizer que devemos relativizar um pouco essa questão. Como eu disse, quase $50 \%$ da massa de crimes que são processados geralmente são roubos. O roubo é na verdade uma prática muito comum entre as classes populares. Penso que a ausência da propriedade faz com que elas tenham uma inclinação maior por essa opção. Não se vê pobres cometendo crimes de colarinho branco, o que também é mais ou menos óbvio: eles não têm acesso aos meios de produzir esse tipo de crime. Isso significa que devemos avaliar a impunidade em dois níveis: de um lado, a impunidade do ponto de vista das classes sociais, das classes preferencialmente puníveis; e, de outro, a impunidade do ponto de vista daqueles que cometem os mesmos crimes, ou seja, que indivíduos são preferencialmente liberados, ou têm certas imunidades, e quais não têm. Seria necessária uma pesquisa qualitativa para se verificar como funcionam as imunidades, como determinadas categorias vão na verdade se beneficiar de uma espécie de imunidade que livra os indivíduos que a elas pertencem do processo punitivo.

\section{Ronaldo Porto Macedo Júnior}

Sou do Ministério Público do Estado de São Paulo. Queria fazer uma pergunta ao professor Joaquim Falcão. Um dos temas caros ao professor Falcão é a questão da cultura jurídica e a questão correlata do ensino jurídico, e me parece que, tomando ao pé da letra o tema do seminário, que é acesso à justiça e não acesso ao Judiciário, ele amplia bastante essa discussão. Primeiro porque caberia perguntar qual justiça: se é uma justiça liberal, ou uma justiça social, com todas as dificuldades que envolvem a determinação deste conceito indeterminado. Minha primeira pergunta é neste sentido, por que não se insere nessa questão do acesso à justiça a questão da reformulação da cultura jurídica e do ensino jurídico?

Outra indagação diz respeito à busca de mecanismos extrajudiciais para a formulação, para o encontro, para a efetivação da experiência da justiça. Ou seja, essa desjudicialização da justiça nos coloca diante de dois polos de um mesmo problema. De um lado, a preocupação, que me pareceu presente também na colocação do Dr. Celso Campilongo, sobre como os problemas são vistos pelos juízes (e a pesquisa do IDESP demonstra isso), especificamente no que se refere à excessiva judicialização dos conflitos. O professor Joaquim Falcão também tocou nesse tema quando falou dos motivos pelos quais o Supremo muitas vezes não decide e dos riscos que há (é evidente) em jogar todos os conflitos sociais para o Judiciário. Por outro lado, essa importância da criação de mecanismos extrajudiciais para a busca dessa justiça.

Do ponto de vista teórico, que linhas o Sr. seguiria fazer essa distinção? Até que ponto deve ir o Judiciário, até que ponto não deve ir, até que ponto a busca da justiça deve ser reservada aos mecanismos judiciais e até que ponto não deve? 
Por fim, uma rápida observação com relação aos paradoxos que o professor Celso Campilongo salientou na pesquisa do IDESP. Chamou-me a atenção, até pela minha condição de promotor, o fato de que, se por um lado, fica demonstrado na pesquisa que os juízes reconhecem que uma das mudanças da Constituição de 88 foi a ampliação de poderes do Ministério Público, por outro lado $37 \%$ também reconhecem que essa ampliação se deveu em grande medida à intervenção do Ministério Público na área dos interesses sociais e coletivos. Aliado ao fato de que hoje em dia o Ministério Público ainda acaba por ter um monopólio de fato, apesar de não ter o monopólio jurídico, na propositura de ações civis públicas, notadamente na área de meio ambiente e do consumidor, paradoxalmente o Judiciário vai reconhecer (na tabela 14), como foi lembrado pelo professor Celso Campilongo, que há uma compatibilização possível entre o direito positivo e a defesa dos interesses coletivos. Curiosamente, uma parcela dessa compatibilização é feita pelo Ministério Público. O Ministério Público acaba sendo o agente que leva essas demandas coletivas, e por isso ele tem uma importância fundamental; mas, a despeito disso é visto com extrema reserva pelo Judiciário.

\section{Joaquim Falcão}

O tema da cultura está embutido em duas ou três observações que fiz. O pacto do monopólio tem uma dimensão profissional e uma dimensão técnicojurídica. Para quem tem uma visão interna do sistema judiciário, esse é um dos aspectos mais difíceis de serem combatidos.

Veja-se o Supremo Tribunal Federal. Temos discutido se ele é uma corte constitucional ou um outro tipo de tribunal. Mas o que é hoje o Supremo? É uma corte processual. Quem manusear as súmulas do Supremo verá que ele tem produzido muito mais decisões processuais que decisões de mérito. Por que isso? Em boa parte isso decorre da cultura das elites que manejam o sistema. É como o due process, é o direito das partes, etc. O processo é importante para que a decisão da justiça seja justa. Ou seja, o conceito de justiça transformou-se, em grande parte, num conceito de processo. E quem fez isso? Os líderes da instituição judiciária, naturalmente, e também alguns interesses, como o dos cartórios, o dos advogados, que prosperam nesse meio hermenêutico. O cidadão comum é incapaz de lidar com esse processo, mas há um consenso de que sem processo não se tem due process, não se assegura adequadamente a defesa. Eu reconheço a importância disso, a necessidade da "jus" processual, mas o fato é que, hoje, o Supremo é uma corte que se preocupa muito mais com decisões processuais que com decisões substantivas.
A sua segunda questão - a da linha de demarcação onde o Estado deve ou não deter o monopólio da administração da justiça -, é dificílima. Não poderia respondê-la de maneira taxativa. Digo apenas que o monopólio estatal, como tem sido concebido, não é mais viável. É uma ambição que não se realiza. A justiça tem a ambição de monopolizar a adjudicação (em caso de conflitos) de normas, riqueza e força. Mas ela não consegue. A vida nas favelas, ou qualquer pesquisa que se faça mostra isso. O que se vê é a ineficácia da justiça estatal, a impossibilidade de cumprir com a ambição do monopólio. Essa é a questão. Como isso vai ficar, não sei, mas estou convencido de que a sociedade terá que abrir espaço para um sistema mais pluralista. Como o Estado detém a força de coerção legítima, em última instância, ele será de alguma forma o coordenador do sistema, mas será um sistema negociado. O Estado não é onipresente, e não poderá controlar tudo o tempo todo.

O Sérgio Adorno fez menção ao direito penal, que talvez seja diferente sob esse ponto de vista. Lembro- me de uma pesquisa antropológica, chamada "Sua excelência, o comissário", feita nas favelas do Recife. No início, achávamos que a pesquisa deveria chamar-se "Sua excelência, o delegado", porque pensávamos que quem resolvia os conflitos era o delegado. Depois resolvemos baixar para o comissário e, se fôssemos realistas, deveríamos dizer que era o cabo. "Sua excelência, o cabo". O que o autor da pesquisa afirma é que, mesmo em matéria de direito penal (pequenos roubos, estupros, etc.), uma vara de justiça penal resolve só $13 \%$ do número de casos penais que um comissário resolve. Eu poderia até achar, dentro de uma concepção teórica, ou de um "dever ser", que, em matéria penal, a presença do Estado é fundamental. Mas o fato é que é a justiça que se pratica, e que pode até ser insatisfatória, ao menos restaura um mínimo de equilíbrio na comunidade.

\section{Antonio Carlos Arruda}

Sou advogado do SOS - Racismo. Gostaria que o professor Campilongo se estendesse sobre uma observação que ele fez e que é relevante para o nosso dia-adia no SOS - Racismo, e de fato, para todos que trabalham na assistência jurídica gratuita a populações menos privilegiadas. Refiro-me ao paradoxo de que um determinado número de pessoas, embora não acreditando na justiça, se diziam bastante satisfeitas com o atendimento prestado pelo serviço de assistência gratuita. O professor Joaquim Falcão, de certa forma, corroborou essa impressão quando disse que as pessoas mais humildes querem a justiça, embora não a experimentem. 
A experiência que temos tido no SOS - Racismo e em outras das quais participei é que na verdade o que hoje as pessoas mais necessitam, além de justiça, é de alguém que passe a mão sobre a cabeça delas. Tanto é que hoje no SOS a composição do nosso quadro inclui não apenas profissionais de direito, mas também profissionais de outras áreas. Temos sentido a necessidade de criar um encaminhamento dessas pessoas para o programa de saúde da nossa organização. Naturalmente, era impossível que as organizações sociais de São Bernardo do Campo encaminhassem cerca de quatro mil pessoas para o serviço jurídico, mas até que ponto é possível sensibilizar o Poder Judiciário e, acima de tudo, o Ministério Público, que hoje tem funções constitucionais de atendimento à população (e à população carente), para que eles entendam e colaborem com a sociedade, com as organizações sociais, com o Estado, no aprimoramento do atendimento às vítimas da legislação brasileira? Na verdade, as pessoas hoje são vítimas da legislação. Quando o professor Joaquim Falcão fala do cidadão que, mesmo tendo um contrato para sair no dia " $x$ " da casa dele, não vai sair porque não tem onde morar, felizmente a comunidade da Rocinha e algumas outras tem uma saída "interna corporis" para isso. Mas os mais carentes - a maioria da população brasileira - são vítimas da legislação.

\section{Celso Campilongo}

Com relação especificamente aos dados da pesquisa, temos que levar em consideração uma série de fatores. Essas pessoas foram entrevistadas no próprio local de atendimento, isto é, no próprio escritório da assistência judiciária, e isso pode ter criado certo constrangimento: não externar críticas na presença dos advogados ou dos estagiários. Não creio que se possa generalizar a observação de que as pessoas no fundo querem um apoio moral, que se passe a mão na cabeça delas, ou que se faça um agrado, no caso desses atendimentos. No caso das mulheres que comparecem aos grupos de assessoria jurídica gratuita, 70\% procuraram solução para seus problemas matrimoniais, e mais especificamente para separação ou divórcio. Isso não é resolvido com um afago. O que se requer é, de fato, uma medida judicial, um encaminhamento judicial para o problema. É claro que tentativas de reconciliação poderiam eventualmente mitigar esse índice, mas essas pessoas a que me referi procuravam uma medida judicial concreta e achavam que algum encaminhamento estava sendo dado a seu problema. A pesquisa chegou a uma análise qualitativa dos resultados de tais processos, isto é, até que ponto as partes foram de fato atendidas na sua demanda judicial. Mas questionava o usuário do serviço sobre sua expectativa, isto é, sobre o que ele esperava do serviço de assistência judiciária. A resposta que aparecia com maior frequência era: "Espero a solução do meu problema individual". São setores relativamente desorganizados da população que se socorrem do serviço de assessoria jurídica gratuita. Nesse sentido, essas pessoas não procuravam a solução de problemas coletivos, problemas de sua comunidade, de sua categoria profissional, nada disso. Procuravam o serviço de assistência gratuita para resolver seus problemas específicos. No caso das mulheres, majoritariamente, era o problema da separação. No caso dos homens, majoritariamente, problemas trabalhistas, de caráter salarial ou de relacionamento com o empregador. Há até quem diga, jocosamente, que mulher procura a assistência judiciária para brigar com o marido, e homem, quando procura a assistência judiciária, o faz para brigar com o patrão. Mas acho que devemos ter cautela com todas essas generalizações.

\section{Alfredo Attié Jr.}

Sou juiz de Direito no interior de São Paulo. Minha pergunta é dirigida ao professor Joaquim Falcão. Uma grande preocupação que tenho tido diz respeito à questão da legitimidade. Não apenas a legitimidade como é vista pelo Luhmann, mas também de um ponto de vista mais tradicional. Vou citar um artigo da Constituição, embora não queira fazer uma análise positivista. O parágrafo 10 do artigo 10 da Constituição diz que o poder emana do povo, e que este o exerce diretamente mediante uma combinação de formas semidiretas e indiretas (representantes eleitos). A Constituição é clara ao dizer representantes eleitos. Parece-me até que, na presente tentativa de revisão constitucional, o relator, deputado Nelson Jobim, não está propondo modificações quanto a esse aspecto.

Como fica essa questão da legitimidade da representação no que se refere ao Poder Judiciário? E também no caso do Ministério Público, órgão ao qual a Constituição atribui poderes de representação de interesses difusos, coletivos e sociais, tendo como instrumento a ação civil pública? Pergunto se uma parcela dessa incompreensão - dessa visão do Poder Judiciário, do Ministério Público e das profissões jurídicas, dessas que estabelecem entre si esse "pacto profissional" -, advém dessa ausência de legitimação popular?

No século XVIII a questão era mais simples. Os "Federalist Papers", por exemplo, especificamente Madison, dizem que o Judiciário se coloca entre o Legislativo e o povo. Mas como é que um órgão que não tem legitimidade na origem pode se colocar entre o Legislativo e o povo? De onde advém, efetivamente, essa legitimidade? Não deveríamos estar buscando novos modos de 
participação, com o objetivo de quebrar essa visão tradicional do século XVIII? Hoje em dia se diz que o Poder Judiciário tem legitimidade na medida em que ele obedece a lei. A lei é votada pelos representantes do povo, mas nós sabemos que a interpretação da lei pode seguir caminhos diversos e que a lei efetivamente não responde a inúmeros reclamos sociais.

\section{Joaquim Falcão}

A premissa dessa perspectiva é que, como o Supremo não é eleito, ele não é legítimo. Daí a questão: até que ponto o Judiciário, que não é escolhido pela população, nem direta nem indiretamente, consegue firmar sua legitimidade? Acho que é por aquele outro caminho a que me referi parafraseando o Bolívar Lamounier. É pelo resultado, pela experiência. Essa questão do controle do Judiciário, da legitimidade do juiz - se ele deve ser ou não eleito -, só vêm à tona porque o desempenho dele não elimina o fosso entre o ideal e a realidade. Se o ideal de justiça não corresponde à experiência de justiça, surge a brecha para esse questionamento da legitimidade. Se o Supremo, como é hoje escolhido, estivesse produzindo sentenças capazes de reduzir esse conflito e isso fosse uma experiência social não da minoria, mas da maioria, não estaríamos discutindo o controle do Judiciário, nem questionando os métodos pelos quais os juízes estão sendo escolhidos. A legitimidade não estaria na dependência só do processo, visto que estaria sendo substantiva.

Se o Supremo tivesse tido a sensibilidade de se sintonizar melhor com a sociedade, teria evitado essa questão do controle do Judiciário. Esse controle que se vem propondo já é uma espécie de segunda instância. Já que ele decide pouco e decide de maneira elitista, o cidadão se pergunta por que ele está lá. E acaba questionando os procedimentos pelos quais são escolhidos os membros do Supremo. Não estou defendendo a escolha eletiva dos juízes, e sim dizendo que essa questão não estaria sendo colocada hoje, no Brasil, se a instituição fosse aberta.

Da mesma forma, os procuradores, desde 1988, têm o desafio de se legitimar diante da sociedade. O atual Procurador Geral da República, Aristides Junqueira, o Procurador de Justiça do Rio, Antonio Carlos Biscaia, e outros, têm consciência disso. Eles trabalham no sentido da construção institucional, usam a comunicação e usam muito bem casos exemplares para tentar transformar o ideal de um procurador independente em uma realidade disseminada na experiência social. É com receio que eu vejo a proposta do Supremo de agora escolher quem são os três procuradores. O Supremo não conseguiu ainda - e imagino que já tenha isso como tema -, firmar sua própria imagem, sua própria legitimidade. Ele agora está preocupado com o sucesso do Procurador. Tudo indica que a revisão constitucional, se ocorrer, irá reforçar o Supremo, remodelando a definição dos papéis do Procurador. Resumindo, a legitimação é um processo permanente, a comunicação é fundamental, o "institutional building" é fundamental para que os nossos ideais de justiça se realizem na experiência social. Só quando a experiência é falha é que se questiona o procedimento da escolha dos seus representantes.

\section{José Murilo de Carvalho}

Farei duas observações. Quanto à exposição do Dr. Celso Campilongo, francamente não vejo contradição alguma entre os dados da PNAD e os dados da pesquisa sobre assistência jurídica. Acho que há um problema semântico. A pergunta fala de confiança na justiça e está falando no Judiciário na realidade. Os dados da PNAD indicam, a meu ver, que as pessoas não recorrem ao Judiciário porque não têm confiança no sistema judiciário. Na pergunta seguinte a resposta é porque é ineficiente, porque é caro e inclusive porque têm medo da própria polícia. Quando aparece uma assistência mais efetiva, que mostra às pessoas que pode ajudá-las a ter acesso, todo mundo se interessa porque todo mundo quer justiça. $\mathrm{O}$ que as pessoas criticam é um sistema que não produz justiça. Então, realmente não vejo que haja contradição entre esses dois resultados.

Um problema que o professor Falcão levantou, e que é instigante e desafiador, é o da desmonopolização da justiça. Não ficou claro para mim qual seria a alternativa ao monopólio. E também não sei se a igualdade perante a lei, que para mim permanece uma norma básica de justiça, pode ser efetivamente conseguida sem que o Estado esteja envolvido, na condição de guardião da lei. No caso do Brasil, a igualdade perante a lei pode ser até uma definição ainda primária de justiça, mas não chegamos nem a essa prática primária de justiça. Eu perguntaria se você não está pensando na sobremesa antes de ter o feijão com arroz, e se, no Brasil, a prioridade não seria ainda essa coisa elementar, a ação do Estado? Lembre-se que já tivemos inclusive no passado uma justiça eletiva que cuidava de pequenas causas. O antigo juiz de paz era uma justiça eletiva e tinha uma eficiência grande em resolver pequenas causas. Minha dúvida, portanto, é se a prioridade não continua sendo a ação do Estado no sentido de tornar mais democrático o acesso à justiça e de efetivar realmente a igualdade perante a lei. 


\section{Celso Campilongo}

Com relação à primeira observação, eu concordo integralmente. Esses dados podem ser lidos na perspectiva indicada, que aponta uma compatibilidade entre eles. Eu concordo integralmente, e tendo em vista a importância da pergunta dirigida ao professor Falcão, vou deixar que ele responda e depois, se possível, farei também um comentário a respeito.

\section{Joaquim Falcão}

Seguirei um caminho indutivo. Existe no Legislativo uma série de projetos de lei sobre arbitragem, sobretudo sobre o mundo de negócios. O ponto crucial da arbitragem é o seguinte: em situações "x", as partes escolhendo o árbitro e o árbitro obedecendo a procedimentos pertinentes à situação " $x$ ", todos determinados por lei do Estado, a decisão não é mais suscetível de apreciação pelo Judiciário. Isso quer dizer que eu preciso de uma legislação do Estado que determine esse enclave, esse espaço, esse subsistema onde passam a existir limites à interferência do Estado. O juiz não apreciará mais o mérito da decisão, se tiver cumprido aqueles requisitos.

Esse exemplo talvez esclareça o que eu quero dizer. Não estou dizendo que a arbitragem escapa completamente ao Estado. A presença do Estado continua a ser indispensável em determinados tipos de regulamentação. Mas ele pode criar uma outra política judicial e legislativa, onde reconhece determinadas instâncias e essas instâncias são ao mesmo tempo limites para a atuação dele. $\mathrm{O}$ caso da arbitragem é isso. Todas as tentativas de legalizar a questão da arbitragem esbarram em dificuldades, porque a justiça acha que não, que se ela conceder status de coisa julgada à decisão arbitrada estará quebrando o seu conceito de justiça, ou seja, o monopólio.

Outro exemplo: na Rocinha, como se resolve a pendência, se a escritura de compra e venda diz que o morador tem que sair em três meses e este diz que não pode sair? Pode-se criar uma instância em que a justiça reconheça, até determinado nível, a validade dessas interpretações interpares, intercomunitárias. Ou seja, podemos pensar em um sistema que anteponha limites à justiça, ou à prestação jurisdicional pelo Estado.

Quanto à questão da igualdade perante a lei, estou completamente de acordo com o professor José Murilo. Não estou propondo a desigualdade, e sim tentando relativizar essa dicotomia de que só o Estado faz a igualdade perante a lei. Numa sociedade pluralista, podem existir distintas maneiras de se atingir esse ideal, a partir de consensos parciais. Um desses consensos diria respeito aos limites da atuação do Judiciário.

\section{Celso Campilongo}

Eu me permitiria um pequeno comentário que me parece fundamental a respeito da igualdade. $\mathrm{O}$ direito estatal, o monopólio da produção do direito a partir do Estado, vem revestido de uma série de critérios democráticos. Dentre esses critérios, esse que enfatiza a igualdade perante a lei. A questão das garantias democráticas do processo de produção legislativa, a eleição de representantes, o trâmite do processo nos parlamentos, tudo isso vem balizado por regras que procuram, pelo menos do ponto de vista formal, garantir um mínimo de igualdade. No caso da aplicação do direito pelo Poder Judiciário, há o devido processo legal, a garantia da ampla defesa, a possibilidade de um sistema recursal, tudo isso também objetivando uma maior igualdade entre as partes.

Quando transferimos essa discussão do plano do direito estatal para o plano de um direito extraestatal, de um direito informal, um direito produzido pelos movimentos sociais, não há dúvida de que incorremos em um risco seriíssimo. Não estou dizendo que o direito informal seja necessariamente incompatível com a democracia. Esse direito pode até se compatibilizar com a teoria da democracia, mas não existe hoje uma teoria consolidada a partir da qual essa conciliação possa ser empreendida. Quando falo em deslegalização, em delegação do Estado para a sociedade, em novas formas de produção do direito, não estou de maneira alguma fazendo uma apologia disso. Ao contrário, tenho sérias preocupações a respeito do caráter democrático dessas outras formas de direito. Mas que existe uma tendência de ampliação desse espaço, não cabe a menor dúvida.

A passagem do direito estatal para outras formas de jurisdicidade pode eventualmente ser feita sob a égide de princípios democráticos. Mas, numa sociedade como a nossa, a produção dessas novas formas de jurisdicidade pode repassar um grau de desigualdade muito grande, pois esta é a nota característica da sociedade brasileira. Esta é uma hipótese altamente provável. Ou seja, esse direito extraestatal, ao invés de reproduzir uma igualdade formal ou formas de igualdade próprias da democracia liberal, poderia reforçar ainda mais a desigualdade. Este é o alerta que desejo fazer. 


\section{Nelson Saule}

Sou do Instituto Polis. Como advogado, tenho trabalhado em assessoria jurídica a movimentos sociais e também em assistência jurídica à população carente. Uma questão que eu vejo, com base nessa experiência que tive, vai além da necessidade dessa população de ter o acesso à justiça e de pleitear esse direito buscando esses serviços que na verdade não são oferecidos, na maioria, pelo Estado. Em São Paulo, em razão desse pacto profissional a que o professor Joaquim Falcão se referiu, tanto o Ministério Público quanto os procuradores do Estado são contrários e resistentes a que se crie a defensoria pública. Desde a Constituição estadual de 1989, aqui de São Paulo, está prevista a defensoria pública para prestar esses serviços e até hoje ela não foi instituída, em razão justamente desses pactos. $\mathrm{Na}$ verdade, por mais que se fale na informalidade jurídica existente nas comunidades, o que essas comunidades buscam é a institucionalização de seus direitos. Aqui em São Paulo, temos tido vários movimentos para instituir leis. A população que vive em cortiços tem hoje uma legislação municipal que regulamenta seus direitos, porque a lei do inquilinato não prevê regras específicas e precisas para esse caso. O que esses moradores buscam é justamente essa institucionalização, e os moradores de favela também a buscam através de leis e de regularização da posse da terra.

Nesse sentido, pergunto ao professor Celso Campilongo e ao professor Joaquim Falcão se não é necessário, mesmo admitindo que seja necessário desregulamentar e quebrar o monopólio da justiça estatal, assegurar que essa população tenha acesso a esse serviço que é oferecido a todo cidadão. Principalmente a implementação de serviços à população, considerando isso como uma política pública a ser assumida principalmente pelos municípios, já que é um serviço que tem uma relação direta com a população. Reconhecer que o serviço jurídico é fundamental e essencial ao cidadão e que deve ser considerado como serviço essencial, como a saúde e a educação.

\section{Deise Beneditto}

Sou do Geledés. Queria fazer um comentário sobre a exposição do professor Joaquim Falcão, porque existe um detalhe muito especial no Poder Judiciário. A grande verdade é que ele se coloca como um Poder inatingível, imexível, e inabalável. Por outro lado, temos a magistratura, temos também o Ministério Público que de certa forma influencia as decisões do Poder Judiciário. Como a população mais pobre, mais miserável, vai poder acreditar ou vai poder exercer a sua cidadania perante o Poder Judiciário que se apresenta tão poderoso, a ponto de ser visto como uma ameaça? Como a população chega na frente de um juiz, como ela vai se comportar, como vai falar, como vai reagir e como também fica inibido o próprio advogado quando representa um pobre? Que poder tem esse Judiciário, que faz parte da elite, de controlar as decisões da vida das pessoas, e que define na sua própria postura qual é o tipo de vida que as pessoas têm que ter?

\section{Milton Riquelmo de Macedo}

Sou presidente da Confederação Nacional do Ministério Público. Minha intervenção tem mais o sentido de cumprimentar os organizadores e os participantes deste seminário. Nós que acompanhamos, em razão da nossa função, essa problemática da crise no Poder Judiciário temos muito claro que um dos problemas que dão margem a essa crise é, sobretudo a ausência do Poder Judiciário. Por isso cumprimento os magistrados aqui presentes, que estão buscando esse relacionamento com a sociedade civil em seus diversos segmentos e tratando de atenuar esse distanciamento existente entre o Poder Judiciário e o que a sociedade deseja.

Com o Ministério Público é um pouco diferente. Como bem salientou o professor Joaquim Falcão, o Ministério Público, por não ser poder, e nem pretender ser, e sim por ser um órgão que se desvinculou de sua origem, que era ligada aos detentores do poder, caminhou, por sua destinação e por vontade de seus membros, junto à sociedade civil, representando de certa forma a sociedade. Então, o Ministério Público sente essa necessidade de buscar essa aproximação. O Judiciário, por ser poder e porque a maioria de seus integrantes tem uma formação distinta, se isola. Essa nova mentalidade que sentimos hoje no Judiciário pode nos ajudar a resolver em parte essa crise. Um dos problemas da crise do Judiciário é falta de acesso, é dificuldade de acesso. E por que dificuldade de acesso? Esse problema tem várias origens e várias explicações. Mas a maior delas é o problema do acúmulo de serviço, tanto na área cível como na área criminal. Esse acúmulo dificulta o acesso e é originário do ajuste processual. Vemos nos gabinetes dos juízes pilhas e pilhas de processos. O trabalho que a magistratura faz, o Poder Judiciário por seus magistrados e nós do Ministério Público, os advogados que procuram levar os conflitos ao Judiciário, enfrentam esse grande obstáculo, que é o excesso. E excesso sem resultado prático. $\mathrm{Na}$ área cível, a gama de recursos, a possibilidade de procrastinar a decisão, levam a dificuldades de acesso de novas demandas e novos conflitos. Na área criminal, que é mais afeta ao Ministério Público, vemos que o processo criminal também dificulta a participação do 
Ministério Público junto aos fatos criminosos. Temos hoje uma forma de inquérito policial totalmente falida e anacrônica, que dificulta a participação do promotor. Por isso, nas pesquisas mencionadas, podemos perceber que o problema ocorre na origem policial, porque ali não há presença nem do Judiciário nem do Ministério Público. Na fase judicial, as decisões tendem a ter um equilíbrio maior.

É muito importante que a visão do Judiciário seja alargada e se tome mais transparente. A pesquisa do IDESP revela de forma patente que a participação do Ministério Público na defesa dos interesses difusos e coletivos, inovação trazida pela Constituição de 1988, não é considerada positiva pelo Poder Judiciário. Por esse aspecto e pela opinião a respeito do controle externo, rejeitado por $85 \%$ dos magistrados, temos demonstrada a tendência do Judiciário em se hermetizar, em praticar a política da ostra, em fechar-se em si mesmo. Com a evolução da sociedade, não é mais possível ter essa visão. São oportunidades como esta que nos levam a crer que futuramente podemos ter uma nova visão do Judiciário brasileiro.

Gostaria de fazer mais um comentário ao professor Falcão, no que se refere ao monopólio da justiça. A experiência da pesquisa junto à Rocinha indica que a sociedade clama pelo judiciário, embora idealize novos métodos de distribuição da justiça. Ela quer ter seus conflitos decididos pelo Judiciário. Ela vê dificuldades, mas na verdade é da natureza humana ter alguém em quem se acredita e que realmente tenha decisões eficientes e rápidas para que esses conflitos sejam decididos. Acho que a preferência da sociedade é nesse sentido. Então temos que realmente imaginar meios para que a justiça seja mais rápida e eficiente.

\section{Celso Campilongo}

Gostaria de fazer um rápido comentário com relação à pergunta do Nelson Saule. Toda essa legislação - talvez menos no caso da legislação de cortiços, mas sim no tocante ao Estatuto da Criança e do Adolescente, a legislação no campo da saúde e mesmo a legislação de defesa do consumidor - é uma legislação muitíssimo influenciada por movimentos sociais. A pauta de reivindicações dos movimentos sociais na área da saúde e da criança e do adolescente foi praticamente incorporada aos textos legais. Estes são, portanto, um tipo de legislação completamente distinta da legislação tradicional. Daí o acerto da observação do professor Joaquim Falcão de que há muito mais um processo de reinstitucionalização do que de desinstitucionalização da conflituosidade. Essa nova legalidade não trabalha com uma perspectiva fechada de ordenamento jurídico. Ao contrário, quando a legislação de saúde remete aos conselhos de saúde, e a legislação da criança e do adolescente remete aos conselhos tutelares, a legislação do consumidor às convenções coletivas de consumo, o que se vê é uma perspectiva aberta de ordenamento, ou seja, uma perspectiva antidogmática. Ao invés de trabalhar com o conceito da lei geral, universal e abstrata, trabalha-se com uma lei específica, aplicável ao caso concreto: uma legislação especial, criada na dinâmica desses movimentos. Ao invés de trabalhar com uma visão retrospectiva ou repressiva do direito, essa legislação trabalha numa perspectiva promocional, e funcional da legislação. Os juristas não estão habituados a estudar e muito menos a aplicar esse tipo de legislação. Daí as dificuldades que retardam a eficácia da legislação nos campos da saúde e da criança e do adolescente. Ou seja, ainda que os movimentos sociais estejam reivindicando a institucionalização desses direitos, essa institucionalização se faz de uma maneira em boa medida antagônica com a concepção tradicional de legalidade.

\section{Sérgio Adorno}

Um comentário final sobre o tema da desmonopolização da justiça. Tendo a concordar com o professor Joaquim Falcão em que determinadas situações furtos que ocorram numa comunidade, certos tipos de contravenções, etc. possam ser resolvidas por instâncias outras que não necessariamente o aparelho judiciário. O problema, entretanto, é que hoje grande parte da massa de crimes provém da chamada criminalidade urbana organizada, do crime organizado. Aí vira um problema. Como é que se vai desmonopolizar a justiça frente a uma situação de confronto entre um poder cada vez mais forte e instâncias judiciais fragilizadas? O problema é mais complexo do que o simples acesso à justiça. No meu entender, o problema está ligado à responsabilidade penal. A justiça criminal tem como base a ideia da responsabilidade penal, centrada na figura do indivíduo. Hoje, com o crescimento da criminalidade urbana organizada, o que precisa ser discutido não é mais a responsabilidade penal individualizada, e sim a responsabilidade coletiva. Como pensar isso? É uma questão extremamente complicada. A impunidade certamente é muito alta porque a própria magistratura, hoje, em função do próprio inquérito e do processo, está desorientada no sentido de poder identificar com precisão quem são os responsáveis. A criminalidade organizada dilui a responsabilidade penal. Portanto, esse problema é mais complexo, envolve a filosofia das penas e a filosofia do direito de punir. 


\section{Sueli Carneiro}

Em relação a essa questão da desinstitucionalização, gostaria de dizer que, do ponto de vista do movimento social organizado, particularmente dos movimentos negro e de mulheres, nós representamos segmentos que querem o acesso à justiça institucionalizada. Particularmente os negros, historicamente, temos estado à margem de tudo que é institucional neste país, vivemos num mercado de trabalho informal e não temos acesso à justiça. Portanto, realizamos a cidadania através da incorporação institucional dessas temáticas.

\section{Joaquim Falcão}

Quero concluir com um exemplo e um esclarecimento. Foi bastante debatida aqui a relação entre a justiça do Estado e a possibilidade de se ter mecanismos outros que não a justiça do Estado para resolver conflitos. Voltando à situação da Rocinha, se há um conflito de morador ou de locação, e o morador não sai, como o proprietário resolve o problema? Ele tenta negociar. A Rocinha tem quatro administradoras que vendem e compram, tudo corretíssimo. Ou então ele vai para as associações, vai à administradora ou vai à associação. Não vai buscar a administradora como administradora, mas como uma terceira parte que vai decidir, ou seja, como juiz. Ou então vai à associação (que na realidade são três), que também vai decidir. Ou então vai à $\mathrm{OAB}$, que tem um escritório de advogados, não para atuar como advogados, mas para atuar como o terceiro a que me referi. Ou vai para o escritório da Procuradoria, que também existe lá, ou vai ao Clube de Xadrez. Quando esgota tudo isso, onde é que ele vai? Vai ao "capo di tutti capi", o traficante da Rocinha. Em minha pesquisa já encontrei dois casos em que o interessado chegou a ele e disse: "O senhor tem que me proteger, ele entrou na justiça contra mim". Ele disse: "Então está na justiça". Encerrou o assunto. E toda a comunidade respeita. $\mathrm{O}$ próprio traficante reforça a crença comum na necessidade do Judiciário. $\mathrm{O}$ que eu percebo nessa situação é a necessidade de se ter várias instâncias para resolver, mas o Judiciário é ainda a instância ideal. Como o ideal é ineficaz, torna-se necessário ter essa coisa toda. Essa minha observação é para esclarecer que não estou fazendo apologia nem da justiça formal, nem da justiça informal, nem do juiz conservador, nem do juiz alternativo; nem estou dizendo que a justiça nascida da sociedade é necessariamente mais igualitária que a prestada pelo Estado. Estou dizendo, isto sim, que precisamos compreender melhor as relações entre essas diferentes instâncias.
Não estou me fixando nessas dicotomias. "Fora o monopólio do Estado, agora vamos fazer com que o mercado faça justiça", não é meu lema. Não é isso. E mais: acho que quem devia conduzir o processo de modernização da Justiça é a própria Justiça.

\section{Floriza Verucci}

Meus efusivos agradecimentos aos integrantes desta mesa e aos participantes deste debate. Penso que esta primeira sessão já nos proporcionou muitas ideias instigantes para o prosseguimento do seminário. 


\section{SEGUNDA SESSÃO}

\section{Organização e funcionamento do Poder Judiciário}

Moderador: José Renato Nalin

Expositores: Walter Ceneviva

Manoel Alceu Afonso Ferreira

Maria da Glória Bonelli

Maria Tereza Sadek

Rogério Bastos Arantes

\section{José Renato Nalini}

Boa tarde, senhoras e senhores, agradeço a honra de participar deste encontro representando a Escola Paulista da Magistratura. Dando início aos trabalhos da tarde, após a proveitosa sessão da manhã, vamos ouvir o professor Walter Ceneviva.

\section{Walter Ceneviva}

É uma alegria participar deste seminário, e, sobretudo numa sessão presidida pelo meu estimado amigo José Renato Nalini, juiz eminente e que tem dado à Escola Paulista da Magistratura uma contribuição sumamente proveitosa.

Ao tratar da organização e do funcionamento do Poder Judiciário, pareceme que devemos inseri-lo no quadro da nova Constituição brasileira, que cria uma rica pluralidade de justiças. No Brasil, pode haver grave injustiça oficial do Estado, mas não é por falta de justiças. Nós temos, na visão mais geral inscrita na Constituição, as justiças setoriais, a eleitoral, a trabalhista, a federal, a dos Estados, a militar, isso sem falar no espaço interno de cada uma delas, ora com juízes em tribunais regionais, ora com um órgão superior da justiça estadual, ora com mais de um tribunal em nível de alçada, criando uma complexidade estrutural que é, por inteiro, incompreendida pelo povo. Verifico na minha experiência profissional, que até membros das camadas mais educadas da sociedade têm grave dificuldade de compreensão de como é essa justiça plúrima: por que o caso tal vai para o juiz tal e o caso tal não vai, por que fulano obteve tal ou qual vantagem que beltrano não obteve?

Já me convenci de que é impossível - no atual estágio da nossa evolução histórica e dos conhecimentos disponíveis para o povo brasileiro - transmitir essa informação. Creio que mesmo os jornalistas, em sua maioria, não têm uma visão completa da estrutura da justiça e da máquina do Estado no direito brasileiro.

Essa complexidade talvez esteja relacionada ao que se tem chamado de crise do sistema judiciário. Essa crise decorre, em parte, das dificuldades de todo o processo econômico brasileiro, da falta de meios, da falta de elementos humanos, do aumento crescente da clientela da justiça, que não é acompanhado pelo aumento da infraestrutura do Estado. Decorre também, em parte, de causas atribuíveis aos próprios juízes, que, sob a assertiva de que não lhes cabe senão cumprir a lei, nem sempre reivindicam, com o poder que representam, a solução cabível perante os outros poderes. Deficiências humanas graves, tanto entre os juízes, como também no corpo administrativo, que se expressam como insuficiência numérica, mas também como insuficiência qualitativa, obstaculizam a obtenção da justiça pelo cliente, tanto pelo cliente profissional, que é o advogado, como pelo cliente último, que é o cidadão. A obtenção do direito através da máquina do Estado transforma-se muitas vezes num pesadelo, num tormento difícil de entender, e assim a máquina torna-se incapaz de satisfazer aquilo que, no conceito clássico, consistia em atribuir a cada um o que é seu.

Em função dessas deficiências, surge um subproduto. Costuma-se dizer (e digo isso de brincadeira, porque é evidentemente falso) que há três coisas impossíveis: Deus errar, assar manteiga no espeto e oficial de justiça honesto. Digo isso porque um dos segmentos da máquina estatal da justiça, relacionado com o cumprimento de mandados para a intimação das pessoas, é o oficial de justiça. É evidente que a imensa maioria deles é composta de gente da maior probidade e da maior seriedade, que recusa qualquer espórtula, qualquer acréscimo monetário para o cumprimento das suas diligências e até para o não cumprimento delas. Mas vez por outra tem acontecido o cumprimento ou descumprimento de mandados mediante retribuição.

Essas coisas repercutem muito ao nível popular e exacerbam a descrença nas possibilidades do Judiciário de realizar e bem cumprir a sua função. O aumento da procura agrava esse perfil e resulta em que uma grande parte da clientela potencial do Poder Judiciário não chega a ter a oportunidade de comparecer perante a máquina do Estado, ou resulta insatisfeita, porque comparece e vê as coisas se passarem com tal lentidão, com tal complexidade de alternativas que é inviável compreender por que aquelas coisas acontecem daquele jeito.

Ainda há pouco tempo, numa posse no Primeiro Tribunal de Alçada Civil, neste Estado de São Paulo que passa por ser o mais rico da federação brasileira, o 
ilustre presidente confessou que havia paralisados na distribuição da Corte 48 mil processos. Isto é, que 48 mil casos aguardavam distribuição, para que o juiz designado examinasse os autos e pusesse os respectivos processos em julgamento. Diante de um comentário meu de que essa deficiência era insuportável, recebi de amigos que tenho naquela Corte uma crítica no sentido de que eu estava sendo injusto, porque aquela deficiência não decorria de deficiências próprias da máquina judiciária, e sim de deficiências da estrutura do Estado, que não propiciava os meios materiais e humanos, e nem mesmo o espaço necessário para que aquelas dificuldades pudessem ser contornadas. Eu disse: tudo bem, mas se hoje é esse o número de processos parados à porta da distribuição, sem ingresso verdadeiro nos caminhos da justiça prestada pelo Estado, se não se buscar com empenho uma solução para essa enxurrada de processos, no fim do ano serão 80 mil. Pode-se evidentemente dizer que o Judiciário não tem culpa. De fato, em parte não tem. É o conjunto da máquina do Estado, com a legislação complicada, com as insuficiências legislativas para certas soluções em nível estadual, já que um país heterogêneo como o nosso não pode ficar à espera de soluções sempre nacionais. É verdade que o Executivo, ao qual incumbe a construção de prédios, também não se mostra tão favorável a aplicar suas verbas em tais obras, e que muitas vezes prefere obras faraônicas, ou obras que propiciem mais votos, como túneis e pontes. Enfim, há deficiências em toda a máquina, é preciso reconhecer isso.

Mas também é preciso reconhecer que o Judiciário não tem assumido uma atitude enérgica de defesa desses objetivos de aprimoramento e muitas vezes, lamento dizê-lo, tem sacrificado esse empenho mediante composições com o interesse do Executivo. Isso tem acontecido e é sem dúvida uma causa preocupante. Por outro lado, o aumento da conflituosidade decorre de fatores que também são estranhos ao Judiciário. A complexidade processual é apenas uma desculpa para fatos verdadeiros. O avanço da urbanização, por exemplo. Há 50 anos a cidade de São Paulo já era uma metrópole, mas estava integrada numa faixa de 200 quilômetros da costa onde moravam $80 \%$ da população deste país. Há 50 anos, mais de $70 \%$ da população era rural. Hoje isso se inverteu. Hoje, o Brasil inteiro está ocupado e mais de $70 \%$ da população é urbana. Vive-se a citar o exemplo do Japão como estabilidade e como país a ser copiado, e se esquece de que no Japão $99 \%$ da população descende de japoneses. Entre nós, apenas $28 \%$ da população pode afirmar alguma fidelidade de origem. No Japão, entre 1975 e 1985, a maior parte da população continuou a morar na mesma casa; no Brasil, no mesmo período, muitos milhões deixaram de morar no mesmo município.
Estes fatores de instabilidade social repercutem também no Poder Judiciário e no funcionamento da máquina. Há dificuldade de acesso, os processos demoram. O exercício do direito através do Judiciário é muitas vezes uma ficção. Questões simples demoram muito para serem resolvidas e às vezes há liminares concedidas, e logo a seguir revogadas, ou liminares reiteradas. Do ponto de vista do cidadão comum, não adianta muito explicar que o juiz examina a situação e concede a liminar sem ingressar no mérito da causa, e o faz tão só para evitar que, se fosse definitivo o resultado, ele se tornaria inócuo se a liminar não fosse concedida. Uma apreciação, portanto, estranha ao mérito da questão.

E há o crescimento da demanda. Há também o custo da demanda. Não só o custo oficial, as custas processuais, mas também as custas que decorrem do próprio processamento, da ida ao processo, da ida às varas. E também os honorários dos advogados, pobres deles, em relação aos quais há que se dizer que têm todo o direito aos seus honorários, até porque advogado sou. A complicação do discurso, sem dúvida, é outra causa dessa dificuldade da compreensão do direito pelo povo. Mas não é uma dificuldade nossa. Pensa-se que o Judiciário é muito complicado, e que são os advogados brasileiros que criam essa dificuldade. Quando alguém me diz isso, sempre respondo: "Não perca seu precioso tempo. Leia Shakespeare, na segunda cena do segundo ato do Henrique VI, segunda parte, e lá encontrará a melhor de todas as respostas, que já tem 500 anos de idade". É que nessa cena os personagens discutem como resolver os problemas do reino e um deles dá a solução: "Em primeiro lugar, matemos todos os advogados". Graças a Deus, essa receita não foi cumprida, senão não estaria aqui lhes falando.

Não faz muito tempo, correu na Universidade de Berkeley a seguinte história. Os cientistas americanos não estão mais usando ratos em experiências, estão usando advogados. Em primeiro lugar porque tem mais advogados do que ratos, em segundo porque os advogados são muito mais espertos que os ratos, e em terceiro e último porque não há nenhum perigo de os cientistas se afeiçoarem aos advogados.

E os juízes? Os juízes também, soleníssimos, distantes, afastados do povo e tentando afastar-se do conjunto social ao qual pertencem. Na gíria dos delinquentes, o juiz se chama "curioso". Curioso porque só pergunta e nem sempre dá a resposta adequada para as perguntas que formula. Os advogados encaram os promotores de um modo geral como complicadores, burocratas, pessoas alheias à realidade social subjacente, mais preocupados com o formalismo legalista do que com a realização do justo. Também não é justa essa queixa, mas devemos reconhecer que ela tem 
sido veiculada com frequência. Eu acho que o Ministério Público é um organismo extraordinariamente importante na prestação da justiça.

Fala-se muito no problema dos meios: mais gente, informática, eventualmente a desprofissionalização dos julgadores, recurso à conciliação, menos recursos interponíveis, simplificação dos processos. Tudo isso tem sido aventado entre as possíveis soluções. Porém, há empecilhos visíveis. Não adianta dizer que é preciso aumentar os meios disponíveis se não há dinheiro.

O governo vive queixando-se de que não tem dinheiro. Também existe a carência de recursos humanos. A Escola Paulista da Magistratura, qual o Dr. Nalini tem dado uma contribuição extraordinária, recebe os candidatos à magistratura e trata de prepará-los. Mas as deficiências começam pelo ensino. Formam-se advogados em grande número, muitos inaptos para o exercício da profissão, e muitos juízes chegam à magistratura não só extremamente jovens, mas também sem suficiente conhecimento da vida, sem nunca terem visto uma promissória, uma duplicata, um contrato de locação, sem terem vivido efetivamente as dificuldades da existência cotidiana e os problemas que dela decorrem. As complicações processuais e as nossas tradições, oriundas das ordenações, complicadíssimas, dificultosas, aquelas expressões clássicas das longas petições, tudo isso complica. São questões que extrapolam o nível puro do jurídico, que ingressam no social, dificultando a prestação da justiça pelo Estado. Insuficiências de tal monta só ao longo do tempo serão resolvidas.

Temos hoje cerca de 330 mil advogados no Brasil; ou seja, 330 mil pessoas inscritas na Ordem dos Advogados e aptas para o exercício da profissão. O número de juízes não chega a 20 mil. No Estado de São Paulo, deve andar pela casa dos 2.500, na justiça do Estado. Ou seja, é evidente que a máquina judiciária do Estado de São Paulo não pode acolher os quatro milhões de processos em andamento (em números redondos). Esse é um gargalo não facilmente ultrapassável, no atual estágio das coisas.

As coisas se complicam, também, porque a justiça é um monopólio do Estado e é um monopólio dos juristas, o que me valeu recentemente, quando proferi uma conferência, uma crítica vigorosa. Uma pessoa me interpelou: "Mas essa sua visão é corporativa. Por que o julgamento deve ser dos juízes e não de toda a sociedade?".

Respondi que está estabelecido assim na Constituição e também que sem uma organização judiciária formal nenhum Estado democrático pode sobreviver.
O conjunto das informações que ora lhes transmito, numa tentativa de resumo de aspectos que me pareceram relevantes e que encontram origem no texto constitucional, é a indicação das dificuldades e das soluções possíveis que tentei resumir nesta breve fala. Obrigado.

\section{José Renato Nalini}

Tenho certeza de que a fala sempre lúcida do Dr. Walter Ceneviva, mestre de todos nós, deve ter suscitado indagações que poderão ser satisfeitas no final. Dando prosseguimento aos trabalhos, passo a palavra ao Dr. Manoel Alceu Afonso Ferreira.

\section{Manoel Alceu Afonso Ferreira}

Meus caros José Renato Nalini, Maria Tereza Sadek, Maria da Glória Bonelli, Rogério Arantes, meu caríssimo Walter Ceneviva, colega e amigo, senhoras e senhores, antes de mais nada, quero agradecer ao IDESP e ao Nalini a gentileza do convite.

O tema proposto diz respeito às dificuldades e às propostas de reforma do Poder Judiciário. Confesso que tenho a esse respeito uma visão talvez um pouco simplista. No enfoque dessa matéria, eu não teorizo, não especulo, apenas vivo a realidade do advogado. Do advogado que diariamente impetra e que tardiamente recebe a resposta àquilo que impetrou.

$\mathrm{Na}$ pesquisa que o IDESP realizou, consultando apenas em São Paulo 297 juízes, a grande maioria, 76,9\%, reconhece que o Judiciário vive uma crise. E $85 \%$ desses entrevistados registraram que o principal obstáculo ao bom andamento do Poder Judiciário é a falta de recursos materiais. Eu tenho uma visão muito próxima a isso. Na minha brevíssima incursão que fiz pela vida pública, quando ocupei a Secretaria da Justiça, tive disso uma impressão muito nítida. A Secretaria da Justiça do Estado de São Paulo tem $0,69 \%$ do orçamento estadual. Vou repetir: $0,69 \%$. E deve, com esses 0,69\%, construir todos os edifícios forenses do Estado. São Paulo tem, segundo os últimos dados, de 1.610 juízes para responder por 35 ou 36 milhões de habitantes, um número aproximado, talvez um pouco menor, de promotores públicos. De forma que, ao menos nessa corrida, nós, advogados, estamos ganhando, pois somos cerca de 150 mil advogados inscritos.

O Judiciário teoricamente recebe do orçamento do Estado - da arrecadação do ICMS - cerca de 6\%. Essa é a parcela da arrecadação do Estado destinada a 
suprir as necessidades do Poder Judiciário, desse grande mudo, mudo por culpa alheia, mas também por culpa própria. O Judiciário não tem sabido usar o seu legítimo poder de pressão para reclamar parcela maior dos recursos do Estado. $\mathrm{O}$ Judiciário tem sido um grande mudo e apenas episodicamente, por manifestações isoladas e individuais de alguns de seus membros, tem reclamado.

Matérias jornalísticas demonstram que ainda existe uma absoluta ignorância coletiva quanto ao que seja o Poder Judiciário e as instituições afins. Não faz muito tempo, li numa revista que o Ministério Público foi criado pela Constituição de 1988. Ora, isso é uma afronta ao conhecimento elementar de qualquer primeiro-anista de Direito, algo inadmissível de ser repetido num órgão de comunicação de nível nacional.

Diz-se que o grande defeito, a grande deficiência do Poder Judiciário é a morosidade. Certamente, o Poder Judiciário não é um poder rápido, um poder ágil. Não o é por uma série de circunstâncias, a começar por aquelas de ordem material a que me referi, e também porque o arcabouço constitucional brasileiro, na defesa ou no resguardo da amplitude do direito de defesa e do devido processo legal, tem permitido a processualização de lides, ou de litígios, de maneira a estendê-las em excesso. De qualquer maneira, um Judiciário moroso é preferível à injustiça rápida. Certamente, a justiça no Brasil não pode ser feita sob a pressão dos veículos de comunicação ou de reclamações populares, como os pedidos de justiçamento. O Judiciário tem tentado se manter afastado dessas pressões, e na maior parte das vezes tem conseguido.

Mas mesmo nesse aspecto de morosidade da justiça, essa morosidade não é total. Há uma justiça no Brasil, uma justiça especializada, que tem uma eficiência extraordinária. Refiro- me à justiça eleitoral. A justiça eleitoral tem dado seguidas demonstrações de celeridade processual. As reclamações, os pleitos eleitorais têm sido julgados na sua grande maioria com muita rapidez, desde os atos preparatórios e da arrecadação de votos, até a divulgação de resultados e o julgamento dos recursos referentes a essas disputas. Digo isso talvez com a deformação de quem pertenceu a essa justiça, mas ao mesmo tempo com o conhecimento de quem nela viveu de maneira intensa.

Outra experiência que a meu ver desmistifica a morosidade da justiça como conceito genérico são os juizados especiais. Os juizados especiais criados na Constituição, os juizados de conciliação, os juizados de pequenas causas, têm funcionado de maneira positiva e benéfica para a coletividade em geral, constituindo-se, inclusive, em fator de aproximação entre a população e o judiciário, sempre visto como um poder distante da realidade e dos conflitos sociais. Os juizados de conciliação e de pequenas causas têm, a meu ver, respondido satisfatoriamente a essa reclamação de morosidade.

Como se conserta tudo isso? Em primeiro lugar, como no mundo inteiro, conserta-se com mais dinheiro. Não é possível que o Judiciário continue a ser o aleijão da República, o aleijão dos poderes, que permita ao chefe de um outro poder dizer que um determinado tribunal descumpre a lei. É preciso que o Judiciário receba dotações orçamentárias que lhe sejam suficientes e que o retirem desse estado de prostração em que vive, desse estado de absoluta humildade, dessa situação de mudo que não reclama, que não vai aos jornais, que não se abre, que permanece fechado e procura às vezes canais de veiculação, sempre usando aquela linguagem de que há pouco o Walter Ceneviva falava, a linguagem fechada, o latinês, que agrava o distanciamento. Eu tenho vez por outra assistido entrevistas de membros do Poder Judiciário e tenho sentido essa absoluta dificuldade de comunicação, essa falta que apenas a experiência e o início dessa tentativa de comunicação com a sociedade permitirá superar.

Veja-se a questão da informatização do Judiciário. No Brasil, com cerca de 10 milhões de processos em andamento, com menos de 10 mil juízes, é impensável que a informatização não tenha sido ainda empreendida, quando os escritórios já se adaptaram a ela. O advogado usa o computador e o juiz usa a velha Remington 1946 que herdou de seu antecessor. Urge simplificar os procedimentos, e utilizar a permissão constitucional que os Estados legislem acerca de procedimentos. Isso tem sido feitos no Brasil de uma maneira muito tímida. Os Estados têm um temor reverencial pela União, e por isso não legislam em matéria de procedimento, com poucas exceções. Certamente, a realidade forense de São Paulo é diferente da realidade do Rio Grande do Norte e, no entanto, os Estados não têm se valido dessa prerrogativa. A amplitude de recursos: veja-se quantos e quantos recursos são usados, alongando os procedimentos; recursos que poderiam ser suprimidos sem qualquer malefício aos direitos e garantias.

A prática dos juízes: se não me engano, hoje, o tempo de prática profissional exigido para aqueles que postulam acesso à carreira da magistratura é de dois anos. É muito pouco. Permite-se que postulantes com dois anos - e dois anos valendo o estágio, vale dizer, valendo desde o quarto ano da faculdade -, funcionários de cartório, funcionários de polícia, todos esses podem postular acesso ao Judiciário, passam nos concursos e são nomeados juízes. E vão se defrontar pela primeira vez com o Walter Ceneviva, por exemplo! Recebem um 
mandado de segurança impetrado pelo Walter Ceneviva, com a riqueza e a capacidade que lhe são inerentes, e têm que enfrentar aquilo.

Há uma distância entre os juízes e o povo, e eu penso, sobretudo, nas pequenas comarcas, porque a dificuldade judiciária do Brasil reside menos nos tribunais, na segunda instância, e muito mais na primeira instância. Como se dá a aproximação entre o juiz da pequena comarca e as chamadas forças vivas da comunidade? Como se faz isso? Se ele se aproxima demais, não pode julgar mais nada. Se se aproxima de menos, vale dizer se se distancia muito, acaba assumindo aquela atitude olímpica, acima do bem e do mal, distanciado da coletividade. Como se resolve esse conflito? Resolve-se casuisticamente. Não há outra maneira. $\mathrm{Eu}$ tenho conhecido juízes que têm mantido essa aproximação com as chamadas forças vivas da comunidade e nem por isso têm perdido a independência. Mas conheço outros também que se aproximam demais da comunidade, a um ponto tal que ficam impedidos de julgar qualquer pleito porque muitas vezes autor e réu são seus amigos, conhecidos ou relacionados.

São estas as considerações que desejava fazer, e que em grande parte repetem aquilo que o Walter Ceneviva, com muito mais propriedade e brilho, disse antes. Muito obrigado pela atenção.

\section{José Renato Nalini}

Nossos agradecimentos ao Dr. Manoel Alceu. Passo agora a palavra à $\operatorname{Dr}^{\mathrm{a}}$ Maria da Glória Bonelli, socióloga, uma das responsáveis pela pesquisa em que se baseia este seminário.

\section{Maria da Glória Bonelli}

Minha colaboração será de caráter sociológico, uma contribuição que toma como ponto de partida os estudos sobre profissões. Vou olhar a profissão de juiz sob essa perspectiva. Quero chamar a atenção para o fato de que, embora a profissão de juiz seja muito importante socialmente e os juízes sejam parte de um poder, e por isso sejam poderosos, eles também sofrem a ação de condicionantes sociais que limitam em algum grau sua atuação.

Procurarei delinear alguns desses condicionantes e algumas das possibilidades e responsabilidades que os juízes têm diante de si, dentro da forma como eles podem agir. A maneira pela qual concebo o campo da justiça tem como base a constatação de que os juízes fazem parte de um sistema de profissões, sistema esse que se caracteriza por uma competição tanto com profissões da área de direito (competição intraprofissional), como também com profissões de outras áreas (competição interprofissional). O campo é movimentado pela competição interna à magistratura, ou seja, entre os segmentos que existem nessa carreira: pela maneira segundo a qual a magistratura lida com a promotoria, com a advocacia, com a defensoria pública, também pela maneira pela qual ela recorre à mídia ou a outras profissões para dar eficácia prática a sua visão de mundo.

Os dados coletados na pesquisa do IDESP indicam uma grande homogeneidade no perfil desse profissional, que é por sua vez adequado aos valores predominantes na sociedade. O membro do Poder Judiciário nem é tão jovem nem é idoso. Embora a idade de ingresso seja 23 anos, com menos de 30 anos, em 1993, havia apenas $7 \%$ dos entrevistados; e com 60 anos ou mais eram menos de 5\%. Há um empate entre as faixas etárias que vão de 34 a 43 anos e entre 44 e 53 anos, tendo cada uma dessas duas faixas $30 \%$ da amostra.

Quanto ao gênero, é uma profissão esmagadoramente masculina, com apenas $11 \%$ de participação de mulheres. $\mathrm{O}$ ingresso do contingente feminino vem se intensificando: nos anos 90, as mulheres atingiram $25 \%$ dos candidatos selecionados para a carreira entre 1990 e 1993. É importante frisar a existência de discriminação social contra a participação feminina na posição de juiz, fato que também se verifica nos dados disponíveis sobre o judiciário norte-americano.

Lá, em 1985, as mulheres eram apenas 7\% do corpo de juízes e tendiam a ter melhores oportunidades de ingresso na carreira pelas formas de seleção que não pressupunham escolhas eleitorais. $\mathrm{O}$ voto discriminava mais as mulheres, reduzindo sua participação relativa no conjunto da profissão. Ou seja, há uma discriminação latente na sociedade, e o exemplo norte americano sugere que ela se manifesta mais intensamente quando a escolha se dá prioritariamente pela via eleitoral.

A valorização social da profissão de juiz e de desembargador é muito elevada. Os magistrados estão no topo da hierarquia ocupacional. Eles pensam sobre si mesmos como quem tem nas mãos a responsabilidade de decidir sobre a vida de outras pessoas. Nesse ponto se assemelham aos médicos, que também veem a si mesmos como tendo nas mãos a vida de seus clientes. Eles também angariam respeitabilidade e status social através da articulação do monopólio de um conhecimento científico, com uma imagem pública de cunho altruísta. Essa construção reforça ainda mais a deferência social em relação à magistratura e inflaciona a aceitação externa quanto ao grau de elitização da carreira. Associa-se à condição de julgador um grande acúmulo de conhecimento e saber que tipifica 53 
os segmentos mais bem posicionados socialmente. Essa caracterização contribui para a percepção popular do Judiciário como um poder distanciado e irreal.

A magistratura brasileira reflete as condições de mobilidade social vivenciadas no país nas décadas de 60 e 70. Do total de entrevistados pelo IDESP, $30 \%$ são filhos de pais que não chegaram a terminar o primeiro grau. São membros das gerações que foram impulsionadas pela industrialização, pela urbanização e pelo período do chamado "milagre econômico". Cinquenta e seis por cento $(56 \%)$ dos entrevistados ascenderam socialmente concluindo o curso de Direito. Dos 39\% que possuem o mesmo nível de escolaridade do pai, a maioria é filha de profissionais da área do Direito, indicando uma tendência entrópica e uma socialização precoce no mundo e nos valores jurídicos.

Esta suposição de que existe um padrão de socialização anterior, que favorece o partilhar de sentimentos comuns é reforçada por outro dado: um contingente de $70 \%$ dos juízes com experiência profissional em áreas afins antes de ingressar na magistratura. As principais ocupações desempenhadas antes do ingresso na magistratura são as de advogado e funcionário de cartório. Em função dessa experiência anterior como advogado ou como funcionário de cartório, criam-se internamente duas autoimagens diferentes. Geralmente, os juízes que tiveram experiência como advogados se veem numa posição de melhor avaliar o outro lado, de melhor avaliar a sociedade, diferenciando-se de um padrão que eles atribuem àqueles que vieram do cartório, que é o padrão funcionário público. Os que se veem como advogados tendem a ver-se como mais trabalhadores e tentam se diferenciar, dissociando-se da imagem dos que "não trabalham", que seriam os que começam como funcionários de cartório.

Praticamente todos se referem que existe um tipo de juiz que "não trabalha", mas é impossível identificar quem seriam esses juízes por meio das entrevistas. Todos dizem: "Eu trabalho e sou diferente de alguém que não trabalha". Esse "alguém" a gente nunca localiza, mas todos criam o modelo de que existe um "outro tipo" que não trabalha. Em geral, esse tipo é descrito como o funcionário público, com todas as avaliações e conotações negativas que essa imagem tem hoje em nossa sociedade.

O tempo despendido entre a conclusão do curso superior e o ingresso na magistratura é curto. A carreira tende a começar nos cinco primeiros anos após a conclusão do bacharelado, com incidência maior na faixa entre dois e três anos de formado. Há evidência de que a socialização na carreira é mais bem implementada quando o profissional ainda não desenvolveu identidades profissionais com outras atividades vinculadas à área do Direito. O grupo apresenta um perfil masculino, numa faixa etária intermediária, em ascensão social, com alguma socialização anterior nos valores jurídicos ou no ambiente do Judiciário. Tudo isso afiança o modelo de juiz com o qual a magistratura parece se identificar: a imagem de um homem moderado, responsável, maduro, capaz de mediar e de julgar sem destoar dos valores predominantes na sociedade. O corpo selecionado através dos exames sugere que esse controle se faz sentir no momento de ingresso na carreira.

Em comparação com a seleção do judiciário norte-americano, que mistura sete diferentes formas de ingresso na carreira, via eleição, via nomeação e/ou mérito, o judiciário brasileiro é uma instituição apolítica. O que o caracteriza, aqui, é o seu aspecto ideológico, mais que seu perfil político. E é identificado na elevada homogeneização do perfil de seus membros. O quinto constitucional que ingressa apenas nos tribunais de segunda instância com base em outros critérios de seleção apresenta um perfil distinto, aguçando a competição intraprofissional. Os critérios de seleção podem favorecer ou dificultar uma maior diversificação da categoria, interferindo nos sentimentos corporativos.

A morfologia da magistratura acima delineada evidencia a homogeneidade desse grupo profissional, devidamente fortalecida pelos processos de socialização anteriores e pelos critérios de seleção implementados no recrutamento para a carreira. Entretanto, o impacto que algumas correntes minoritárias conseguem na mídia e nas relações e alianças com outras instituições ampliam sua capacidade de vocalizar as tensões decorrentes das disputas profissionais vivenciadas na magistratura. Essa repercussão inflacionada para o mundo exterior ilustra como funciona o sistema profissional no campo do Direito, através das competições e das composições intra e interprofissionais.

Os dados disponíveis demonstram que, embora existam problemas na justiça formal e em seu funcionamento, nada garante que uma justiça informal traria resultados melhores. Há indicações de que uma justiça informal reproduziria de forma mais acentuada a estratificação social e os próprios valores dominantes na sociedade, aumentando a discriminação. A profissionalização da justiça formal e sua intenção corporativa de mostrar sua relevância parece dar-lhes melhores oportunidades de efetivar uma perspectiva mais igualitária, menos discriminatória. Era essa a contribuição que eu desejava trazer a este seminário. Obrigada a todos pela atenção. 


\section{José Renato Nalini}

Foi extremamente interessante a contribuição da $\operatorname{Dr}^{\mathrm{a}}$ Glória Bonelli. Eu como juiz não disponho desses dados, o Judiciário não tem o perfil do seu juiz. O Tribunal de Justiça do Estado de São Paulo tem desenhos de perfil idealizados, ou seja, conforme um paradigma da magistratura. Temos alguns indícios de onde provêm nossos juízes, mas nunca houve um trabalho sério, como agora o IDESP está fazendo, de verificar a origem social, a formação do juiz e o seu comportamento. Isso é muito valioso para todos nós. Agora vamos passar a palavra para a coordenadora dessa pesquisa, a cientista política Maria Tereza Sadek.

\section{Maria Tereza Sadek}

A Dr ${ }^{a}$. Glória Bonelli mostrou a homogeneidade que existe no quadro da nossa magistratura. Para entendermos essa homogeneidade, eu construi uma tipologia, aproveitando um estudo incluí do no livro que o Dr. Nalini escreveu sobre o recrutamento e preparo dos juízes. Muitas vezes, ao analisar a magistratura brasileira, caímos na tentação de imaginar que a realidade de outros países é exatamente igual à nossa ou então a um mundo ideal que não existe em parte alguma. A tipologia que vou expor baseia-se em dois exemplos extremos que encontramos no mundo ocidental. Num extremo, um corpo de magistrados muito homogêneo, cujo melhor exemplo é a magistratura inglesa, e, no outro extremo, um corpo acentuadamente heterogêneo, cujo melhor exemplo é a magistratura francesa, se bem que a magistratura italiana e em certa medida a espanhola poderiam também ser enquadradas nesse caso.

$\mathrm{Na}$ Inglaterra, o ingresso na magistratura não é por concurso, mas, sobretudo por indicação. O juiz inicia sua carreira quando já está bastante adiantado em termos de idade: a média de idade do juiz inglês é de 63 anos. Todo juiz ingressa na magistratura depois de uma longa experiência, seja profissional, seja na vida político-partidária. Por sexo, existe ampla predominância masculina. Segundo dados de 1990, num total de 465 juízes, apenas 17 eram mulheres (3\%). Esse dado sugere que não devemos nos assustar tanto com os nossos $12 \%$ de mulheres... A origem social do juiz inglês é, sobretudo, dos estratos mais altos, a maioria vem de Cambridge ou de Oxford, ou seja, das chamadas "public schools".

A questão ideológica conta muito pouco, porque os juízes ingleses raramente dão entrevistas, não aparecem na televisão. São exatamente o oposto da Suprema Corte norte-americana. O juiz inglês, mesmo estando nas mais altas instâncias da magistratura, não é uma figura pública conhecida. O perfil ideológico ou político-partidário, depois que o aspirante ingressa no Judiciário, é estritamente controlado.

Há um exemplo conhecido na literatura sobre os juízes ingleses: o de uma juíza que, em 1985, participou de uma campanha a favor do desarmamento nuclear e por isso foi afastada do Judiciário, tendo sido negados os recursos que ela impetrou contra essa decisão. A magistratura inglesa é a mais homogênea que conhecemos. Como disse, os juízes têm idade avançada, origem social alta, e formam um corpo predominantemente masculino, que não declara publicamente suas preferências político-partidárias ou ideológicas.

O outro extremo da tipologia é um corpo bastante heterogêneo, que pode ser exemplificado pelos juízes franceses. Na França, a carreira começa muito cedo. Nem mesmo o requisito de dois anos que a nossa Constituição exige para o ingresso na magistratura existe na França. Alguém que recém saiu do curso universitário e entre na Escola de Magistratura francesa, já é um funcionário público francês e é remunerado, nesse estágio preparatório, já como juiz.

A magistratura francesa é uma profissão cada vez mais feminina. Segundo dados de 1990, do total de 5.912 juízes franceses, 2.247 são mulheres. Existe claramente uma "feminização" da profissão na França. Outro dado significativo é que, desde os anos 80, a maior parte dos candidatos à Escola Nacional de Magistratura são mulheres. Cerca de $66 \%$ daqueles que ingressam na Escola Nacional de Magistratura são do sexo feminino. A origem social dos juízes franceses é intermediária, portanto bastante diferente da origem social dos juízes ingleses, e a média de idade do juiz francês é cerca de 30 anos.

Do ponto de vista ideológico e partidário, o judiciário francês é bastante politizado e politicamente polarizado, a começar pelo fato de que está ligado a três grandes organizações sindicais. Existe uma organização sindical de direita, que é a Associação Profissional dos Magistrados; uma de centro, a União Sindical dos Magistrados; e uma de esquerda, o Sindicato da Magistratura.

Tendo em vista essa tipologia, vale a pena indagar o porquê da homogeneidade que encontramos entre os juízes brasileiros. Seria plausível esperar certa heterogeneidade, já que a forma de ingresso na carreira é muito semelhante à francesa, mediante concurso, sendo o concurso, teoricamente, a forma mais democrática de se ingressar na carreira, porque abre as portas para todos. Apesar disso, e da juventude que se observa nesses dois casos, a magistratura brasileira é bastante homogênea. Também no tocante a suas opiniões, 
o grau de concordância que encontramos em relação à maior parte das questões, entre os juízes entrevistados, é muito alto.

No entanto, algumas questões incluídas no questionário mostram diferenciações importantes. Por exemplo, o percentual de juízes entrevistados que concorda com a existência de crise no Judiciário. Dois em cada dez juízes admitiram claramente a existência de crise no Judiciário e cinco admitiram isso pelo menos em termos. Existe, portanto, uma diferença e a pergunta que se impõe é se essa diferença pode ser explicada por características sociológicas ou demográficas do corpo de juízes.

Examinamos, em primeiro lugar, se o fato de ser homem ou mulher interferia no fato de o juiz assumir uma posição mais crítica ou aquiescente em relação à organização judiciária tal como ela existe atualmente. Notamos uma pequena tendência no sentido de os homens serem mais críticos do que as mulheres, mas essa diferença não é estatisticamente significante. Vinte e quatro por cento $(24 \%)$ dos homens e $17 \%$ das mulheres admitiram que o Judiciário brasileiro atravessa hoje uma crise.

Examinamos também a questão idade, ou seja, se faz diferença o juiz ser mais jovem ou mais velho, e, da mesma forma, percebemos que a idade não era um fator explicativo. $\mathrm{O}$ fato de o juiz ser mais jovem ou mais velho não determinava uma diferença em sua avaliação da situação do Judiciário. Como a idade poderia estar sendo influenciada por fatores estranhos ao tempo na magistratura, ou seja, alguém pode ter prestado concurso com mais idade, e então estaríamos perdendo a oportunidade de saber se o fato de alguém estar exercendo a magistratura por mais tempo influencia ou não na formação de seu ponto de vista, tentamos então isolar essa variável. Ou seja, indagamos se o tempo de exercício da magistratura se associa à avaliação que um juiz faz em relação ao Judiciário, e o resultado, mais uma vez, foi negativo: esse fator também não tem peso explicativo.

A posição na carreira, esta sim, se mostrou uma variável importante. $\mathrm{Ou}$ seja, faz diferença se o juiz está na primeira instância ou na segunda instância. Os juízes que estão na segunda instância mostram-se mais críticos (mais dispostos a reconhecer a existência de uma crise) que os juízes de primeira instância. Os percentuais globais são estes: $21 \%$ dos juízes de primeira instância concordaram em que existe uma crise no Judiciário, ao passo que; a cifra correspondente chega a $35 \%$ na segunda instância. São 14 pontos percentuais de diferença.
Do ponto de vista da opinião pública, a questão regional parece relevante. A imprensa frequentemente pressupõe que juízes do Rio Grande do Sul são diferentes dos juízes do Nordeste, que por sua vez seriam diferentes dos de São Paulo, e assim por diante.

Examinamos, então, se a percepção dos juízes diferia em função da região, ou seja, se eles estariam de fato tendo uma socialização diferente pelo fato de estarem em São Paulo ou no Rio Grande do Sul ou em alguma outra região.

Gostaria de lembrar que a nossa pesquisa foi feita em cinco Estados: Rio Grande do Sul, Paraná, São Paulo, Pernambuco e Goiás. O que percebemos é que existe uma pequena (e quero sublinhar pequena) diferença de acordo com a região onde o juiz atua. Os juízes que atuam em Goiás parecem ter uma postura menos crítica do que os do Paraná e do Rio Grande do Sul. Os de São Paulo têm uma posição intermediária e os da Justiça Federal se aproximam um pouco mais dos juízes do Rio Grande do Sul e do Paraná. No entanto, essa diferença não é tão nítida como se poderia supor a partir de alguns relatos da imprensa. O mais provável é aquilo que a Glória Bonelli observou, ou seja, que o grupo que mais se diferencia, embora numericamente reduzido, tem considerável poder de vocalização.

Essa conjectura é reforçada por outro dado da pesquisa. Quando chegamos às causas da morosidade da justiça e do mau funcionamento do Judiciário como um todo, os juízes tidos como mais críticos e mais progressistas são, na realidade, os que menos atribuem tais problemas a fatores internos ao próprio judiciário. Ora, a insuficiência na formação profissional e a lentidão do juiz são dois aspectos vinculados à estrutura do Judiciário, no sentido de que não dependem nem do Executivo nem do Legislativo. Entretanto, esses aspectos não são destacados como os mais importantes, quando comparados a fatores externos, pelos juízes do Rio Grande do Sul e do Paraná, que eram à primeira vista os mais críticos em relação à organização ou às práticas internas do Judiciário. Esta constatação reforça a análise aqui desenvolvida pela Glória Bonelli, que frisou a homogeneidade de origens e de mentalidade existente entre os juízes.

Os dados analisados mostram que a questão do sexo não importa, a questão da idade não importa, o tempo de exercício da magistratura também não importa. Nossa análise converge para a delineação de um corpo bastante homogêneo. As diferenças encontradas não podem ser explicadas por características sociológicas, e sim (até certo ponto) por avaliações ou posições ideológicas internas. Entre os 570 juízes entrevistados, encontramos dois grupos ideologicamente distintos, mas 
não a ponto de se poder falar num grupo heterogêneo - certamente não tão heterogêneo como a magistratura francesa.

Examinamos a opinião dos juízes a respeito da estrutura do Judiciário, das possíveis causas internas e externas do seu mau funcionamento, enfim, de várias questões, e nossa conclusão foi que, em todas essas questões, o grau de concordância é sempre muito alto. As diferenciações encontradas não chegam a colocar os juízes que se distinguem entre si em posições ideologicamente polarizadas.

Eram estes os comentários que desejava fazer. Meu colega Rogério Bastos Arantes irá em seguida complementá-los, não sob o ângulo da magistratura em si, mas das questões institucionais abordadas em nossa pesquisa. Muito obrigada.

\section{José Renato Nalini}

Depois dessa análise também tão percuciente e instigadora, vamos ouvir o cientista político Rogério Bastos Arantes.

\section{Rogério Bastos Arantes}

Um dos eixos de investigação adotados pela pesquisa do IDESP sobre a chamada crise do Judiciário brasileiro é o eixo institucional. Ao lado dos fatores estruturais e dos relativos aos procedimentos judiciais, nossa pesquisa considera que a organização e o funcionamento do Judiciário no Brasil têm íntima relação com a posição alcançada por essa instituição no quadro da separação de poderes, particularmente a partir da Constituição de 1988

Meu argumento é que a evolução política brasileira, mesmo com suas reviravoltas constitucionais e talvez por causa delas, não logrou ainda uma definição clara do papel institucional do Judiciário, frente aos demais poderes e à sociedade. Quando digo papel institucional, não estou me referindo à condição elementar do judiciário como órgão encarregado da prestação de justiça nos conflitos entre particulares, mas à sua condição de poder político, com atribuições e prerrogativas próprias frente ao Legislativo e ao Executivo e como instituição mediadora dos conflitos entre a sociedade e o Estado.

Tomando para comparação os casos dos Estados Unidos e da França, vemos que aí o papel institucional do Judiciário encontra-se bastante bem definido, mesmo que em direções opostas, variando desde a condição de poder político claramente soberano nos Estados Unidos, até a condição de órgão quase meramente administrativo na França. Embora sejam diversos os modelos de organização judiciária, o fato é que, no plano institucional, o Judiciário brasileiro parece não ter encontrado ainda uma identidade bem definida.

O principal indicador da condição política do Judiciário nos tempos modernos é sem dúvida a capacidade de controlar a constitucionalidade dos atos dos outros poderes e de defender a sociedade dos abusos eventualmente cometidos pelo Estado. A atribuição ou não dessa competência é o ponto de partida para a definição dos diversos sistemas judiciais hoje existentes no mundo ocidental. Uma vez atribuída essa capacidade ao Judiciário, podemos fazer outra distinção, qual seja, a que se estabelece entre sistemas que se estruturam com base no modelo difuso, de criação norte-americana, ou no modelo concentrado, de criação austríaca. Sumariamente, no modelo difuso, todo e qualquer juiz pode declarar a inconstitucionalidade das leis no julgamento de casos concretos; no modelo concentrado, essa competência é monopólio de um tribunal especial, as chamadas cortes constitucionais, que podem declarar a inconstitucionalidade das leis, tanto no julgamento de casos concretos, como em ações diretas sobre a lei em si.

Curiosamente, a partir da primeira Constituição republicana, que adotou o princípio difuso puro, várias mudanças foram feitas pelas Constituições seguintes, sempre inspiradas no modelo concentrado, a ponto de transformar o nosso sistema de controle constitucional num sistema híbrido sem paralelo no mundo contemporâneo. A combinação original desses dois sistemas, o difuso e o concentrado, não deve ser (como pensam alguns) motivo de grande alegria. Pelo contrário, julgo que essa combinação é um sinal evidente de que o papel do Judiciário na vida política nacional ainda é ambíguo ou contraditório. A maneira pela qual se encontra estruturado nosso sistema de controle constitucional é um dos principais fatores de agravamento da chamada crise de governabilidade.

A pesquisa do IDESP procurou ouvir os magistrados sobre esse problema. Com relação às modificações introduzidas pela Constituição de 1988, e considerando o funcionamento global das instituições do país, os juízes entrevistados manifestaram-se favoravelmente ao reforço da função de controle constitucional do Supremo, à legitimação de novos agentes para propor ações diretas de inconstitucionalidade, ao mandado de injunção e ao mandado de segurança coletivo - mudanças estas que acentuaram de forma significativa o lado político da atuação da Corte Suprema brasileira.

Os percentuais de aprovação a essas medidas são da ordem de $75 \%$. Entretanto, quando questionados sobre a atuação do Supremo Tribunal Federal nesse mesmo período, ou seja, desde 1988, a avaliação dos juízes vai quase no 
sentido oposto. Não tanto no tocante ao reforço da função de controle constitucional do Supremo. Esta mudança foi considerada positiva por $76 \%$ dos juízes, ao passo que $65 \%$ avaliam que o STF tem cumprido bem essa função; uma diferença, portanto, de $11 \%$. Já no que se refere aos novos mecanismos, como o mandado de injunção e o mandado de segurança coletivo, a aprovação genérica é da ordem de $76 \%$, mas apenas $37 \%$ consideram positiva a atuação do Supremo no sentido de dar eficácia a esses novos instrumentos. Portanto, menos da metade daqueles que aprovam em tese os novos mecanismos consideram que o Supremo tem garantido ou dado eficácia aos mesmos.

Quais seriam as razões dessa discrepância entre a aprovação das mudanças constitucionais e a avaliação do desempenho do Supremo Tribunal na visão dos juízes? É que justamente tais mudanças acentuaram a responsabilidade política da Suprema Corte perante as questões de governo e, de fato, seu comportamento contraditório na defesa da Constituição frente aos atos dos demais poderes não é bem visto pelos juízes inferiores, mais apegados à atuação jurídico-formal.

Outro item da pesquisa do IDESP é capaz de ilustrar melhor a tensão existente entre os papéis político e jurídico-formal que convivem na atuação do Supremo. Os juízes que entrevistamos foram instados a avaliar a atuação do Supremo do ponto de vista da compatibilização da ordem jurídica com o imperativo de combate à inflação. Nenhum outro item do questionário obteve índice tão alto de juízes sem opinião formada: $22 \%$. Muitos dos entrevistados observaram (e com alguma razão) que não é função constitucional do Supremo compatibilizar a ordem jurídica com qualquer objetivo ou política de governo. Sua função é antes aplicar a lei e simplesmente declarar inconstitucionais aquelas que ferirem a Constituição.

O fato de juízes das instâncias inferiores, mais apegados à letra da lei, disporem da prerrogativa de interpretar constitucionalmente as leis (este é o princípio difuso) acabou se constituindo em barreira a ações intervencionistas do governo federal, particularmente após 1988. Embora nossa última Constituição tenha sido adotada há poucos anos, vários exemplos podem ser dados no sentido de ilustrar a tensão existente entre o princípio difuso e os imperativos de governo. Um deles é a Medida Provisória 173, que proibia a concessão de liminares em ações contrárias ao Plano Collor I. Um ano depois, tivemos a proposta de reedição da avocatória entre as medidas do chamado Emendão. Ou ainda, no início de 1993, a Emenda Constitucional número 3 que criou a ação declaratória de constitucionalidade, concentrando mais poderes no Supremo e diminuindo os dos juízes singulares. E por último, a recente medida provisória do governo Itamar Franco, constrangendo a concessão de liminares nos julgamentos envolvendo interesses da União.

Tais medidas, às vezes unilaterais por parte do Executivo, visaram e ainda visam concentrar a competência do controle constitucional das leis no Supremo, não porque este possa ser melhor controlado pelo governo, mas porque a racionalidade do sistema difuso parece incompatível com ações governamentais, consideradas indispensáveis, na área econômica. O que se deseja nesses casos é obter respostas judiciais rápidas e que vinculem outras decisões, mais do que direcionar a atuação do judiciário quanto ao próprio mérito dessas questões. Parece ser essa experiência recente a fonte das reformas que estão sendo propostas na revisão constitucional de 1993. Gostaria de ressaltar duas dessas propostas. Primeiro, a proposta de efeito vinculante das súmulas dos tribunais superiores para os órgãos sob sua jurisdição, e das ações de inconstitucionalidade e constitucionalidade do STF para todos os órgãos judiciais inferiores. Segundo, a reedição da avocatória para questões constitucionais relevantes.

Caso venham a ser aprovadas, estas propostas de alterações no texto constitucional reduziriam significativamente a eficácia do princípio difuso de controle constitucional. Poderiam ir além, inclusive, porque propõem a vinculação da jurisprudência dos tribunais superiores às instâncias inferiores, e as súmulas não se limitam a decisões envolvendo apenas a Constituição. Alcançam também questões atinentes à legislação ordinária.

À época da realização de nossa pesquisa, uma alteração análoga às que estão sendo propostas já havia se efetivado com a Emenda Constitucional $\mathrm{n}^{\mathbf{o}} 3$, aquela que criou a ação declaratória de constitucionalidade, e ainda se discutia a possibilidade da reedição da avocatória. A opinião dos juízes entrevistados a respeito destes dois mecanismos foi contrária a essas mudanças: $45 \%$ dos entrevistados se mostraram desfavoráveis à ação de constitucionalidade com efeito vinculante para as instâncias inferiores, mesmo essa ação já tendo sido aprovada por emenda constitucional, e $74 \%$ se declararam contrários a avocatória. Esses percentuais indicam forte resistência dos juízes inferiores à concentração de competências nos tribunais superiores, o que nos permite presumir que haverá 
enorme polêmica se a revisão constitucional conseguir chegar à discussão do capítulo do Poder Judiciário ${ }^{1}$.

Antevendo essa disputa, o próprio relator da revisão, deputado Nelson Jobim, disse em seu Parecer número 26: "Nesse artigo reside, em nosso ver, aquela que é a mais profunda mudança sugerida quanto ao Poder Judiciário", referindo-se à atribuição de caráter vinculante às súmulas editadas pelos tribunais superiores. Note-se, portanto, que se trata de algo mais importante, na visão do relator, que todas as demais propostas de mudança no Judiciário, incluída aí o tão polêmico órgão de controle externo do judiciário.

\section{Debate}

\section{José Renato Nalini}

Vamos passar de imediato aos debates. Solicito a todos que as questões sejam bem objetivas e que os consulentes se identifiquem ao microfone e indiquem o conferencista a quem é dirigida a indagação.

\section{Achiles Siquara}

(Promotor de Justiça, presidente da Associação do Ministério Público da Bahia)

Ficou claro até agora nesse dia de trabalho que é necessário romper com o imobilismo no que respeita às questões do Judiciário. Se não me falha a memória, li isso numa tese de cátedra do eminente senador da República professor Josaphat Marinho. A tese dele é intitulada "Direito de Revolução", e ao citá-la não quero dizer que prego a Revolução. Apenas lembro uma advertência de Marx (que por ser de Marx não deixa de ser atual): quando chegar a hora em que uns não podem e outros não querem manter a ordem vigente, será a hora da revolução. Um exemplo recente das dificuldades que estamos discutindo foi a crise do Supremo com o Poder Executivo nacional, em que os meios de comunicação, notadamente um que abrange todo o território nacional, declaradamente incitavam o povo a ficar com ódio do Judiciário.

Gostaria de me referir a essa manifestação final do professor Rogério Arantes, para fazer uma pergunta a respeito desse efeito vinculante das decisões. A primeira instância do Judiciário tem sido acolhedora nessa inovação da defesa dos direitos coletivos e dos interesses difusos. A segunda instância tem sido um

${ }^{1}$ A revisão constitucional com quórum reduzido de $3 / 5$ para maioria absoluta, iniciada em outubro de 1993, terminou sem que tais propostas fossem votadas. desastre, extremamente conservadora. Por outro lado, precisamos admitir que os 48 mil processos aqui citados em relação a determinado período numa determinada comarca de São Paulo na verdade são demandas e, se formos buscar questões, serão em número infinitamente menor. O Ministério Público tem preocupação com essa parte do Relatório Jobim no capítulo do Judiciário porque, ao contrário do que a pesquisa mostra, se a segunda instância foi propensa a dizer sim à crise do Judiciário, mais do que a primeira, eu acho que o malefício está na liderança das associações de magistrados que exercem naturalmente uma influência maior sobre a primeira instância e maquiam uma crise que está saltando aos olhos. Isso porque nós que fazemos a luta político-institucional costumamos ser um pouco corporativistas. Assim é natural que a defesa seja às vezes excedida para esse plano. Aproveito para registrar minha homenagem aos professores Manoel Alceu e Rogério Arantes e meu aplauso ao IDESP pela iniciativa do seminário.

\section{Manoel Alceu}

Em primeiro lugar, quero registrar o prazer de rever o ilustre presidente da Associação do Ministério Público da Bahia. Nosso encontro data de algum tempo e eu fico muito contente pela lembrança do amigo. Sempre tive horror a qualquer restrição que se faça à liberdade de criar direito e acho que essas súmulas vinculantes vão nessa direção, vão de encontro ou manietam essa liberdade de criar direito. Todo caso é um caso, isso é da nossa vivência forense. Não há caso rigorosamente igual a outro, até porque, se existisse, a crise do Judiciário estaria resolvida, dar-se- ia a um computador a solução do problema.

Essas súmulas vinculantes restringem esse direito. O juiz é obrigado a se curvar àquilo que o tribunal superior entendeu. Essa ressuscitação (perdoem-me o neologismo um tanto antivernacular) dos acentos do velho direito lusitano a meu ver representam um retrocesso. Eu lastimo que um parlamentar do quilate do advogado Nelson Jobim tenha enxergado nesse expediente ou nessa fórmula uma maneira de enfrentar a morosidade judicial. Vale dizer, impetra-se jurisdição, a parte reclama, toma-se a Súmula 425 e se derruba.

Havia no STF uma súmula que uma vez levou um ilustre advogado de São Paulo a dizer que, se fosse convidado para compor o Supremo, recusaria o convite enquanto existisse a referida súmula. Era a tal súmula da interpretação razoável. $\mathrm{O}$ Supremo não conhecia de recursos se a decisão do tribunal inferior, ou da instância inferior, tivesse essa interpretação razoável. Ora, o que é interpretação razoável? A interpretação ou é certa ou é errada, para efeito da prestação jurisdicional. 
Vou, portanto, inteiramente na sua linha de que a instituição dessas súmulas vinculantes significará um retrocesso na jurisprudência. Vão certamente fazer com que a jurisprudência regrida e se consolide de uma maneira que eu até diria reacionária.

\section{Deise Beneditto}

Sou do Geledés - Instituto da Mulher Negra, e também funcionária do Poder Judiciário. Tenho algumas observações e quero ser breve em respeito às outras pessoas que vão falar. Uma observação em cima do que acontece dentro desse conflito do Poder Judiciário aos olhos de uma pessoa que é funcionária do Poder Judiciário há mais de cinco anos: a figura do juiz. Qual é o juiz com que nós trabalhamos? Temos juízes recém-formados que não sabem nem como manusear um processo e quem acaba ensinando esse juiz são os funcionários de sala, como também são esses funcionários que ensinam os advogados a ver o que é a primeira capa de um processo. Então nós muitas vezes também ajudamos e orientamos juízes, como também orientamos os advogados que vão ao balcão. E a gente sempre tem que ter boa vontade e ganhar um salário baixo. É sempre colocada, e aqui foi bem colocada, a questão de funcionário público ser vagabundo. Isso é um estereótipo como vários estereótipos que tem por aí. A questão de se ter um juiz que já foi funcionário de cartório, do nosso ponto de vista é muito bom, porque minimiza o trabalho daquele que vai ser o escrevente de sala, porque ele já passou pelo cartório, então já sabe o que tem que fazer. Ele já tem um conhecimento de como tem que proceder na parte técnica do processo.

Outra observação que desejo fazer é sobre a comunicação entre o juiz e o funcionário. $\mathrm{O}$ funcionário continua sendo funcionário e servil. O Judiciário coloca: "Você é funcionário, um reles mortal; eu sou juiz, eu sou o poder". Tem funcionários que entram na sala do juiz, assim: "Dá licença, senhor; dá licença, senhor". Até chegar perto já pediu não sei quantas licenças. Tem juízes que nunca entraram num cartório, não sabem como é um cartório, que tem cozinhas dentro do cartório e dentro do Poder Judiciário. Essa é a questão de como se relacionam.

Outra questão também importante é a do poder. A gente tem que trabalhar com oprimido e opressor. Aquele que vem da camada mais baixa da sociedade e que se esforçou para fazer uma universidade, quando vai prestar um concurso e tem oportunidade de ser juiz, ele vai falar: "Agora eu sou o máximo". Isso é uma coisa que vocês devem ter detectado quando fizeram a pesquisa. A questão é interior: "Não me remeta a ver o meu passado miserável, agora eu tenho poder, agora sou juiz".

Uma curiosidade minha é quais são os critérios para uma pessoa se tornar juiz. Dentro do Judiciário, no próprio Tribunal de Justiça, tem aquele quadro dos desembargadores que passaram pela casa douta da sabedoria eterna. $\mathrm{E}$ ali eu nunca vi um juiz negro em 100 anos de abolição. Não chegou nem na primeira instância. Então, eu queria saber como se dá a relação racial no Poder Judiciário. É uma questão muito séria. Como também a ausência de promotores negros. Entre os que trabalham no Judiciário, a maioria é negra, porque é por concurso, e a maioria dos funcionários do Poder Judiciário fazem Direito e acabam ficando atrás da mesa com o diploma engavetado. Na hora de prestar um concurso, muitos se sentem inibidos porque passam na prova escrita, mas quando chegam na prova oral: "Eu sou preto, e aí?". Ninguém vai falar que ele é preto, mas e aí? São alguns detalhes de como isso funciona e como se exercita essa democracia. Eu acredito que o colega da Bahia deve ter alguns pretinhos na magistratura, já que $90 \%$ da população de lá é negra, é impossível não ter. Mas aqui é uma coisa absurda, em 100 anos.

E um outro detalhe é aquela questão: eu acho muito importante que os juízes comecem a colocar uma sandaliazinha Havaiana de vez em quando. Não tem problema entrar num cartório para ver os funcionários; os funcionários não mordem, estão ali trabalhando, não tem problema nenhum. Ficam chamando o juiz de "excelência". Ele não foi batizado com o nome de "excelência", tem um nome, é Roberto ou Antonio, não foi batizado com o título de "excelência". Acho que esses moldes lusitanos é que dificultam o acesso à justiça e o funcionamento dela. E quando o senhor Ceneviva fala do funcionamento do Judiciário, se hoje temos 48 mil processos e no fim do ano teremos 80 mil, é porque vamos ter mais 40 mil pessoas sem ter onde morar, sem ter onde estudar, sem saúde, sem educação e que vão ingressar na marginalidade, que são empurrados para os cadeiões da vida. O Judiciário nunca teve a preocupação com a questão social do país. Do jeito que está indo vai ser um tribunal de justiça em cada esquina, que nem boteco. É o que vai acontecer e não vai ter juiz para isso. Eu só queria fazer essa colocação dos critérios, que para mim é uma questão importante. Obrigada.

\section{José Renato Nalini}

O Dr. Walter Ceneviva se propôs a responder. Eu também não posso deixar de dizer em relação aos critérios de admissão que hoje a magistratura possui negros em número razoável. Há inclusive desembargador negro no órgão especial. Dentre 
os 25 desembargadores que governam o Tribunal de Justiça, temos um que pertence à raça negra e nós nem lembramos se ele é diferente ou não. Tenho vários colegas juízes negros, temos negras na magistratura. Fui promotor por quatro anos, também ingressei com vários negros e nunca sentimos nenhuma restrição.

Como foi bem colocado hoje pela manhã, o negro está pagando um tributo pelo largo período na História deste país em que ele esteve numa situação muito adversa até esse resgate definitivo, uma questão muito ligada à economia. Mas no Tribunal de Justiça não há restrição nenhuma, é só a questão de mérito, de mostrar conhecimento perante critérios que podem ser defeituosos, mas são ainda critérios de conhecimento. O Dr. Manoel Alceu foi várias vezes examinador e acho que essa questão de ser ou não ser negro nunca apareceu.

\section{Manoel Alceu}

Nas cinco vezes em que participei, houve um candidato negro, que foi aprovado. Aliás, candidato de excelente qualidade. Eu gostaria de dizer, antes do Walter Ceneviva, que essa discriminação me faz lembrar os Estados Unidos. Nos Estados Unidos, os $10 \%$ de população negra forneceram 40 ou $45 \%$ dos contingentes que foram lutar no Vietnã. No Brasil, a Escola Naval, o Itamaraty e outras instituições são exemplos manifestos da discriminação racial que existe entre nós. Então acho que o Judiciário não tem sido um agente discriminador. $\mathrm{O}$ que ocorre, efetivamente, é que o patamar de inferioridade econômica em que a população negra vive, no Brasil, tem dificultado inclusive a postulação, isto é, que pessoas de cor negra cheguem a prestar concurso. A discriminação é decorrência de restrições econômicas e de escolaridade. Não acho que exista uma discriminação específica no Poder Judiciário com relação ao negro, como existe no Brasil em muitas outras entidades e instituições. Acho que o Judiciário não tem sido o maior pecador nisso.

\section{Walter Ceneviva}

Eu não queria responder àquilo que nossa companheira ponderou, só dizer que realmente também não acredito numa restrição ao negro, mas sem dúvida sempre houve aqui em São Paulo pelo menos restrição à mulher. O Tribunal de Justiça de São Paulo foi sempre o tribunal do paletó, no sentido de obstar o ingresso das mulheres na magistratura. Há poucos anos, num exame em que o Dr. Manoel Alceu também participou, há não mais de oito anos, ingressou a primeira mulher na magistratura.

\section{Manoel Alceu}

A duras penas.

\section{Walter Ceneviva}

No Tribunal de Justiça, havia quem dissesse, na intimidade, que a mulher é muito instável emocionalmente, que "naqueles períodos" ela não tem condição de julgar. Diziam isso com o maior descaramento.

\section{Manoel Alceu}

Ouvia-se com muita frequência nessa época que a mulher não pode ser boa juíza porque ela raciocina com o útero.

\section{Walter Ceneviva}

Ouvia-se isso, parece brincadeira mas ouvia-se sim. De maneira que o Tribunal de Justiça de São Paulo sempre foi discriminador em relação à mulher. Durante algum tempo, há 30 ou 40 anos, ele era discriminador contra os italianos. Não havia juízes de origem italiana. Depois passou a ser discriminador contra os turcos. Ao longo do tempo houve discriminações praticadas por um segmento altamente conservador.

\section{José Renato Nalini}

De estado civil.

\section{Walter Ceneviva}

Preponderou. Eu conheci um juiz que jamais se separou da mulher, com a qual ele não vivia, porque não ficava bem, ele não seria promovido. $O$ estado civil era um fator relevante na carreira, e assim ele manteve essa situação em vista dos preconceitos que existiam. Mas contra o negro, eu creio que é mais por falta de comparecimento de um segmento negro da população aos concursos do que propriamente devido a algum preconceito.

Por outro lado, eu gostaria de retomar um ponto levantado pela Deise - essa coisa do juiz que não sabe. Isso está criando um subproduto perigoso no Estado de São Paulo. O número de juízes que ingressam jovens na carreira, sem jamais ter visto uma nota promissória ou um contrato de locação, é gravíssimo, porque eles 
estão longe desse insensato mundo, como no título do filme do Terence Stamp. Não têm a menor noção da realidade da vida, não têm nenhum contato com a realidade da vida cotidiana. Têm uma informação teórica sobre o Direito, que às vezes é muito boa, mas essa informação teórica não é compatibilizada com nada, absolutamente nada do substrato vital sobre o qual se apoia. Em decorrência disso, ele logo sofre uma infecção do ego, uma inflamação chamada "juizite". Nomeado juiz, detentor do poder e ignorante, sem conhecimento da prática, se cerca desse superpoder ou dessa inflamação do ego para ser agressivo, desagradável, desrespeitoso.

Posso até contar um episódio sobre um juiz de uma pequena cidade. $\mathrm{O}$ velho advogado chegou para o juiz e quis despachar uma petição. Despachar a petição significa colher o despacho de sua excelência. O juiz, sem olhá-lo, disse assim: "O senhor ponha no protocolo". Diz o velho advogado: "Excelência, eu preciso que vossa excelência despache porque é um despacho ordenatório, a decisão de vossa excelência é necessária na petição". "Ponha no protocolo". O velho advogado, ainda paciente, disse assim: "Olha, excelência, eu preciso de um despacho de vossa excelência. Se vossa excelência agora não puder despachar, eu esperarei todo o tempo porque só sairei daqui quando vossa excelência despachar". Fosse um jovem advogado certamente se assustaria, se atemorizaria, ficaria sem saber o que fazer. Mas o juiz viu que o velho advogado, embora amável, era muito firme. E despachou. Mas despachou, como dizem os juízes, "J.C.L.S.". Isso significa: "Junte-se ao processo e venham-me conclusos para que eu decida". Porque ele não sabia decidir.

Essa agressividade a que a Deise se referiu existe e é um problema muito sério no relacionamento. Decorre do fato de que muitos juízes, no seu noviciado, no seu ingresso, embora tenham algum conhecimento da teoria do Direito, têm pouco conhecimento da realidade. Isso faz com que eles se tornem agressivos e mais distantes ainda do povo. Reconheço que, no Estado de São Paulo e em alguns outros Estados as escolas de magistratura têm feito um esforço nobre no sentido de superar essa dificuldade, pondo o magistrado em contato mais direto com a realidade. Mas, ainda assim é preciso reconhecer que falta um longo caminho a percorrer, caminho cheio de dificuldades, mas nem por isso fico desesperançado, porque acho que elas podem ser resolvidas.

\section{Andrei Koerner}

Sou aluno do Departamento de Ciência Política da USP. Há alguns anos, eu comecei a fazer uma dissertação de mestrado sobre o Poder Judiciário e o meu objeto seria a crise do Poder Judiciário em 1977, no episódio chamado "pacote de abril". Para fazer uma pesquisa de caráter histórico e ver quais eram os antecedentes, comecei a fazer um levantamento bibliográfico e fui vendo que existiam debates praticamente a cada cinco ou dez anos a respeito da chamada crise do Judiciário. Podemos retornar a 74, a 67, a 62, a 55, a 43 e daí por diante, até Nabuco de Araújo, na década de 1850, que basicamente colocou o modelo que está sendo discutido até hoje: a deformação de uma aristocracia de juízes dotados de todas as garantias pessoais e legais que supostamente iria garantir os direitos na sociedade brasileira.

Eu estudei, do século 19 até a República, as propostas de reforma do Poder Judiciário, as quais são apenas parcialmente implementadas ou na maior parte das vezes não dão em nada. Inspirado em Florestan Fernandes, pensei: e se a crise fosse o modo normal de reprodução e de trabalho do Poder Judiciário? Inverti a questão e comecei a pensar quais são as relações de poder que sustentam esse conjunto de instituiçõos e impedem que ele se modernize.

Então, gostaria de colocar algumas questões. É óbvio que a ausência ou o reduzido número de juízes tem uma significação social de restringir o acesso à justiça. O elevado número de formalidades processuais tem, por um lado, uma função de garantia dos direitos individuais, mas, por outro lado, tem uma função protelatória, encarecedora e desencorajadora de muitos que buscam a prestação jurisdicional. Isso, no plano mais específico. Mas que relações foram construídas historicamente entre o judiciário e os poderes políticos, aí pensando o sistema político em sentido amplo? Embora possamos dizer que hoje a situação é diferente, parece-me importante indagar que tipo de relacionamento os juízes estabelecem, por exemplo, com o governo estadual, com o poder político estadual. Se antigamente era necessária uma adesão do juiz à facção oligárquica à qual ele pertencia - eu concluí, no meu trabalho, que o Supremo Tribunal Federal votava de acordo com a política de governadores -, hoje em dia a característica política predominante na relação é que o juiz se omite para não criar empecilhos, vetos ou impedimentos à sua ascensão na carreira.

Assim, eu perguntaria ao Dr. Manoel Alceu e ao Dr. Walter Ceneviva: que tipo de relações os senhores veem hoje como empecilhos à mudança no Poder Judiciário, que tipo de relações políticas internas ao Poder Judiciário, em termos de grupos que predominam e que bloqueiam, e externas, na relação entre Poder Judiciário e Poder Legislativo? À professora. Maria Tereza Sadek eu perguntaria em 
que consistem esses dois grupos ideológicos que ela encontrou no Poder Judiciário, como se caracterizam e se eles se diferenciam também em termos de ação política.

\section{Alfredo Attié Jr.}

O Poder Judiciário tem sido um poder desprezado na teoria constitucional. Se não me engano, Locke não reconhecia o caráter de poder a essa atividade de julgar e Montesquieu reservou uma passagem muito pequena no "Espírito das Leis", simplesmente para dizer que os juízes eram as bocas que deveriam pronunciar a lei. Cito Locke e Montesquieu porque minha pergunta parte dessa questão da concepção tradicional da tripartição de poderes - Judiciário, Executivo e Legislativo - que, a meu ver, hoje, malgrado as classificações mais recentes de Lowenstein e Burdeau, deveriam se resumir a apenas duas, que são o poder de governo e o poder de controle. O Judiciário seria o titular no exercício desse poder de controle. Nesse instante em que acordamos para o Judiciário, em que começamos a estudar o Judiciário, sobretudo no Brasil, eu me pergunto se a proposta do deputado Nelson Jobim não retrataria duas tendências.A primeira, refazer um pacto das elites ou dos poderes, como disse neste seminário o professor Joaquim Falcão, no sentido de evitar que os conflitos cheguem ao Judiciário e evitar a tendência que ora se delineia em que os juízes estão começando a tomar medidas que, certas ou erradas, pelo menos demonstram sua capacidade de entender o seu verdadeiro papel. Em segundo lugar, uma intenção de retirar o Judiciário desse seu papel precípuo de exercer o controle e ligá-lo cada vez mais ao governo, fazer com que ele seja simplesmente um órgão consultor da atividade de governo, de legislar e de administrar. Faço esta pergunta aos Drs. Manoel Alceu e Walter Ceneviva.

\section{Ivana Farina}

Presidente da Associação Goiana do Ministério Público. Os dados da pesquisa estão corretos: por ser mulher, não tão experiente e descendente de italianos, estou em Goiás e não em São Paulo. Quero dirigir-me ao Dr. Walter Ceneviva e Dr. Manoel Alceu, para trazer mais uma indagação sobre a avaliação das propostas de reforma hoje em debate no Brasil. Nós aqui estamos unânimes em que a estrutura judiciária não funciona a contento. No que diz respeito à proposta de reforma, quero discordar em parte do que foi dito até agora sobre o exercício necessário para o ingresso na carreira da magistratura. Embora sendo do Ministério Público e atuando num Estado onde o Judiciário, pela pesquisa, foi considerado não tão crítico (com o que eu concordo), acho que hoje esse exercício a ser exigido se daria nessa estrutura comprometida e falida que nós estamos aqui pretendendo reformar. Nessa linha, não estaríamos fugindo daqueles que são os verdadeiros problemas - os aspectos estrutural, institucional e ideológico -, que são o cerne do problema da prestação da atividade jurisdicional, quer por operadores do Judiciário ou do Ministério Público, quer por advogados? Não seria o "bis in nidem" esse exercício renovado numa prática que se quer renovar? É essa a discordância.

\section{Liliana Mercadante Mortari}

Sou promotora de justiça criminal na capital. Dirijo minha pergunta à professora. Maria Tereza Sadek. Nós estamos debatendo exatamente, como disse a pessoa que me antecedeu, organização e funcionamento do Poder Judiciário, e analisando dificuldades e propostas de reformas. Em primeiro lugar, eu concordaria com dois pontos suscitados pelo professor Manoel Alceu, quanto à falta de verba do Poder Judiciário (e isso vale também para o Ministério Público) e a necessidade de mudanças processuais, para se poder agilizar o sistema, que seriam um caminho fácil de se perseguir.

Por outro lado, tendo em vista os resultados da pesquisa do IDESP, observo dois outros fatores. A senhora se disse surpresa ao notar que os juízes do Rio Grande do Sul, aparentemente mais críticos, não foram assim tão críticos quando disseram que a lentidão dos juízes e a falta de preparo deles próprios fossem fatores de agravamento da crise do Poder Judiciário. A mim essa constatação não causou assombro pelo seguinte: minha experiência de promotora de justiça (sou promotora há seis anos) me faz ver que ambas as instituições, Ministério Público e Magistratura, padecem de uma falta de vontade política para agir. Isso é facilmente detectável quando a situação requer que essas instituições atuem, conjunta ou separadamente, no sentido de mostrar à sociedade a que vieram.

Então eu pergunto: um dos aspectos preponderantes dessa crise, na qual se pode incluir o Ministério Público, não seria justamente o imobilismo, que me parece ser alimentado de cima para baixo pelos integrantes dos órgãos superiores dessas instituições? Essa tendência ao imobilismo e a essa falta de vontade política de agir que existe em ambas? Quando uma instituição estabelece uma prioridade e parte para a ação, os resultados costumam aparecer e em regra costumam causar bom resultado perante a sociedade. 


\section{Luís Antonio Nusdeo}

Sou promotor de justiça em Osasco e membro da Associação do Ministério Público Democrático. Na esteira das perguntas que acabam de ser feitas, gostaria de saber da professora Maria Tereza Sadek - tendo em vista sua tese de que existe uma homogeneidade muito grande no pensamento dos juízes e que o grupo que podemos chamar de dissidente tem uma vocalização maior do que sua representatividade numérica - até que ponto esse grupo atua no interior das corporações e como esse conflito se desenvolve na condução das políticas implementadas pelos tribunais?

\section{Bolivar Lamounier}

Gostaria de retomar a questão do recrutamento de mulheres e de pessoas de cor negra para a magistratura. Não gostaria de repisar o que ocorreu no passado, e sim de perguntar se há alguma medida positiva em estudo, algum esforço de sensibilização, de discussão, de diálogo, no momento em que os concursos são realizados, com o objetivo de corrigir as distorções eventualmente existentes. Que o passado brasileiro foi marcado por uma grande insensibilidade e mesmo por discriminação em relação a esses grupos nós sabemos. Minha indagação é se alguma medida,compatível com os critérios de qualidade e com a necessária formalidade da instituição, poderia ser tomada no sentido de aumentar a sensibilidade ao recrutamento de pessoas de cor e de mulheres para a magistratura?

\section{Manoel Alceu}

Basicamente, o que ocorre nas relações Judiciário e Executivo (vou falar das relações externas) é o seguinte: o Judiciário tem uma autonomia orçamentária garantida na Constituição, mas infelizmente o Executivo continua com o caixa e o Judiciário tem de ir ao Executivo mendigar as suas verbas. O Executivo tem o controle político do Legislativo, e assim o Judiciário passa às mãos do Executivo e do Legislativo quando necessita de recursos. Tem que pedir, implorar aquilo que a Constituição lhe assegura. Eu tive a intenção (não consegui) de estabelecer já uma destinação diferente a partir da arrecadação, como se faz com as universidades e com a habitação popular. Destinar diretamente esses recursos ao Judiciário para que ele, conhecedor das suas necessidades, gerisse esse caixa.

Com relação à segunda pergunta, da redução do Judiciário na proposta Jobim, foi levantado se isso não significaria uma redução do Judiciário como poder de controle dos demais poderes e da vida social em geral. Eu acho que sim.
Acho que essa proposta amesquinha o Poder Judiciário e reduz a prolação jurisdicional. Acho perigoso esse caminho, porque a comunicação do Judiciário é difícil. São poucos os seminários em que uma questão como essa é debatida. Questões como essa não ganham as manchetes dos jornais, não aparecem na Vênus Platinada. Ficam no circuito interno, em nossas especulações e esperanças.

Sobre a experiência em magistratura - a pergunta sobre a relevância dessa experiência, já que ela vem de uma realidade viciada - o problema é que essa é a realidade que temos. Queremos mudá-la, mas por enquanto ela existe. Acho que a experiência é necessária e que a inexperiência é um desserviço à justiça.

O professor Lamounier retomou a questão do ingresso de mulheres e negros na magistratura. Quero lhe dar um depoimento: participei da primeira banca em São Paulo, na qual foram aprovadas as três primeiras mulheres. Aprovadas por um golpe de sorte. As comissões de concurso são compostas por representantes do Judiciário e um representante da Ordem dos Advogados. Quando entrei na primeira dessas reuniões, eu me sentia realmente alheio a tudo. Aquilo era um mundo que eu não conhecia, que não tinha vivido. E pensava de onde tinha vindo aquele pessoal. As restrições ao ingresso de mulheres eram alegações ou insinuações grosseiras, como já foi mencionado aqui. Lembro-me de um participante daquela banca dizer o seguinte: como poderia uma mulher ser juíza em Presidente Venceslau? Como iria enfrentar as reivindicações dos sem-terra? Isso era dito explicitamente, pública e despudoradamente. Felizmente - o golpe de sorte a que me referi -, um dos membros da comissão mostrava-se sensível ao ingresso do sexo oposto, e foi graças a isso que, pouco a pouco, fomos captando a simpatia dos demais membros da comissão e conseguimos aprovar as três primeiras mulheres. E assim mesmo, divulgado o resultado do concurso, um ilustre membro do Tribunal, de dedo em riste, dirigiu-se ao presidente da comissão para dizer: "V. Ex $x^{a}$ será responsável pelo sepultamento da magistratura de São Paulo". Eu ouvi isso!

Com relação aos negros, nos vários concursos de que participei, tive apenas um candidato negro, que foi aprovado, e não por "bondade", não. Foi aprovado porque efetivamente merecia.

\section{Maria Tereza Sadek}

Sobre a questão da homogeneidade do perfil da magistratura, penso que é um dado que precisa ser levado em consideração em qualquer intento de reforma. Certamente, um grupo heterogêneo é mais fácil de se quebrar por dentro. Não 
quero dizer que a magistratura brasileira seja um grupo absolutamente uniforme. O que estamos afirmando, com base nos dados da pesquisa do IDESP, é que as manifestações dos juízes em resposta às perguntas que lhes fizemos não foram muito diferenciadas e menos ainda ideologicamente polarizadas.

Na questão da vontade política, vou até me permitir citar Vitor Nunes Leal, que em 1975 já dizia: "Sim, precisamos fazer uma reforma do Judiciário, há reformas materiais muito importantes que precisam ser feitas, mas isoladas elas não surtirão efeito. Sem vontade política nada vai ser resolvido". Temos exemplos da importância da vontade política para se fazer alguma coisa. O Tribunal de Minas Gerais (aliás, li isso na coluna do Dr. Walter Ceneviva) em questão de dois meses resolveu todos os processos em atraso naquele tribunal. Isso é vontade política? Certamente é. Precisamos de uma boa dose dessa vontade para superar a crise do Judiciário.

\section{José Renato Nalini}

Antes de passar a palavra ao Dr. Walter Ceneviva, gostaria de registrar que, em São Paulo, dois tribunais fizeram a distribuição de todo o acervo. O Segundo Tribunal de Alçada Civil está zerando seu movimento e o Tribunal de Alçada Criminal conseguiu reduzir em dois meses o seu acervo de 28 mil para 19 mil processos.

\section{Walter Ceneviva}

O caso de Minas foi por mutirão dos juízes de primeira instância, eliminando um milhão de processos em um ano, do acervo que eles tinham.

Voltando as questões mais gerais, infelizmente a relação do juiz com o poder político é uma relação de subordinação. O Poder Judiciário tem mantido uma atitude de composição, nunca de enfrentamento, e isso vale até para questões em que a aplicação da lei o favoreceria. Há uma tendência lamentável de aceitação do estado de coisas existente. Apesar da independência administrativa e econômica que a Constituição lhe assegura, o Judiciário sempre vai na base da composição, inclusive encaminhando sua proposta através do Executivo, em vez de o fazer diretamente ao Legislativo.

$\mathrm{Na}$ relação interna, há também um problema político que precisa ser reconhecido. Nos tribunais com maior número de juízes, ocorre a criação do chamado órgão especial, formado pelos 25 juízes mais antigos. E há nesse órgão especial uma deficiência marcante: eles são os juízes mais antigos, têm 20/30 anos de carreira e perderam (para usar a terminologia moderna) todo o contato com as bases do Judiciário. A enorme transformação social desses últimos 30 anos, eles não chegaram a perceber. Quando um juizinho novo conversa com um desembargador, é como se um estivesse falando sânscrito ocidental e o outro alemão do sul da Bavária. Eles não se entendem.

Discutiu-se também aqui a tendência a evitar que muitas questões cheguem ao Judiciário. Essa tendência realmente existe. Como o Judiciário não resolve, é preciso encontrar outros caminhos. Um desses caminhos é a arbitragem, é a conciliação efetivada em juizados pequenos, e assim por diante. Há uma tendência a ligar o Judiciário ao governo, debilitando-o como órgão julgador? Quando era presidente da Associação dos Magistrados Brasileiros, o ministro Sidney Sanches disse isso com todas as letras: "O Poder Judiciário no Brasil não é poder, é função". É função porque não atua como poder. É preciso que ele atue como poder e ele até hoje ainda não conseguiu criar o empuxo necessário para a decolagem em sua plataforma de lançamento.

No que se refere ao exercício preparatório, é bom que se tenha um exercício mais longo, (desde que não seja nos moldes ingleses, em que o aspirante só se torna juiz com idade média de 63 anos), num país em que $75 \%$ da população não tem 35 anos. E tampouco esse exercício fictício que existe aqui: se o cidadão tem carteira de advogado, já se supõe que ele esteja no exercício, ainda que ele não faça nada com sua carteira, a não ser obter prisão especial se cometer algum delito.

Existe, na prática ou em estudos, alguma medida que corrija as distorções existentes nos concursos de admissão, perguntou o Bolívar Lamounier. Distinções de sexo e raça são, há muito tempo, proibidas pelas Constituições brasileiras. Contudo, o Tribunal de Justiça de São Paulo não ligava a mínima para isso. A $\mathrm{Dr}^{\mathrm{a}}$ Floriza Verucci, aqui presente, viveu alguns episódios que comprovam o que estou dizendo, e nós temos outras colegas que também viveram. $\mathrm{O}$ tribunal não ligava a mínima para a lei. O que é um paradoxo: imaginem que o órgão de cúpula do Judiciário do Estado mais importante da nação discriminava vergonhosamente as mulheres, e isso há apenas oito anos.

Um subproduto de tudo isso é o imobilismo a que se referiu a $\operatorname{Dr}^{\mathrm{a}}$ Liliana Mercadante, e que a senhora, como promotora, sabe que existe no Ministério Público e no Judiciário. Como há esse espírito de composição, essa discrição que se pratica para salvar aparências resulta no imobilismo. Mesmo os juízes de primeiro grau das instâncias inferiores têm preocupação com sua carreira. Não são loucos de tomar qualquer atitude que o velho desembargador do órgão especial possa considerar um tanto ousada. Se o desembargador souber que o jovem juiz foi a um 
bar tomar uma cerveja, ele (juiz) pode ficar mal visto. O imobilismo não é só da atitude judicante, é da atitude pessoal dele. Isso é ruim. O juiz se torna um extraterreno, um ET da justiça.

\section{Maria da Glória Bonelli}

Gostaria de encerrar com um comentário adicional sobre a questão da carreira. Não devemos ter a ilusão de que exista um tipo ideal de juiz, aquela pessoa com muita experiência, de 50 anos, maduro, culto, que fala cinco línguas e entende a sociedade como um todo. A carreira não é projetada para atingir esse objetivo. É projetada para uma pessoa que vai começar batalhando em alguma comarca distante do interior. O iniciante vai ter que ir para lá, e vai fazer isso aos 30 anos. Aos 50, as pessoas não querem mais fazer isso: nessa idade os advogados já ganham mais, já estão bem posicionados na sociedade, já têm uma banca ou clientela, e, portanto não vão ingressar no Judiciário nessa altura. Então, a alternativa é selecionar entre os que se oferecem, e isso eu acredito que o Judiciário tem feito razoavelmente. Ele tem trabalhado sobre a oferta que se apresenta.

O que ele pode fazer (e nisso eu acho que o Bolívar Lamounier tem toda razão) é, em primeiro lugar, adotar uma estratégia de ação afirmativa, esforçando-se para que negros, mulheres e minorias em geral tenham melhores chances de acesso. Isso parece que tem sido feito e a composição da magistratura tenderá a ficar mais diversificada. Hoje existe $25 \%$ de participação feminina. Mas, além disso, acho que é necessário expor os aspirantes e juízes a uma socialização mais diversificada. As escolas de magistratura precisam dar orientação pluralista a suas equipes. Se a função delas é ajudar na formação, que formem e treinem juízes expondo-os à pluralidade, a ideias diferentes. Que convidem pessoas com pontos de vistas distintos para formar suas equipes, para que o conteúdo transmitido não se resuma a um único valor, aos valores do pai advogado, da experiência em cartório como funcionário público, da experiência como advogado. Esse é um mundo muito endogâmico, em contraste com o nosso mundo aqui de fora, cada vez mais aberto. A Escola da Magistratura de São Paulo já deu alguns passos nesse sentido, e essa é uma direção que deve ser reforçada. Vai demorar 20/30 anos para mudar o perfil da profissão? Vai, e daí? Algum dia vai repercutir. O que precisamos fazer é apostar numa ação afirmativa para tornar mais aberta e pluralista a formação da magistratura.

\section{José Renato Nalini}

Infelizmente tenho que encerrar, embora meu desejo fosse me alongar sobre cada um desses temas, e principalmente sobre a Escola, que a meu ver é uma novidade importante no Poder Judiciário. É uma inovação, e acredito que ela terá papel importante na reforma do Judiciário. Além dos aspectos referentes a recursos materiais, processos e dinheiro, a reforma deve ser dirigida à consciência dos juízes, deve passar pela sensibilidade do juiz. A Escola pode contribuir para a construção de um sentido ético, formando um juiz comprometido com a prestação da justiça a uma comunidade que tem um terço de miseráveis, de gente que não se alimenta, que não tem emprego, que não tem nada. Desses juízes deve-se exigir algo mais do que conhecer Direito. É indispensável que ele conheça Direito, mas precisa conhecer mais da humanidade, da vida das pessoas comuns.

Eu fico profundamente angustiado de verificar que o presente debate sobre a reforma do Judiciário não questiona isso. O próprio relator que ameaçou com um controle externo obedeceu fielmente as ordens do Supremo Tribunal Federal, colheu o projeto feito do Supremo, a ponto de hoje o Judiciário de São Paulo estar torcendo para que a revisão não chegue a discutir o Poder Judiciário, porque não houve um envolvimento dos operadores jurídicos, os juízes não foram ouvidos, os promotores não foram ouvidos, a sociedade não foi ouvida e essa reforma não será uma reforma do Judiciário, será uma reforma para manter a hegemonia do Supremo, que nunca foi um órgão do Poder Judiciário. O Supremo é uma corte com outras características, não pode ser considerada um órgão de cúpula do Poder Judiciário. Os juízes que lá chegam, depois se transformam e pensam em outros termos, não pensando no acesso à justiça mas na conservação de práticas tradicionais.

Espero que o IDESP continue a se aproximar da Escola da Magistratura. Precisamos trabalhar juntos, e trabalhar juntos com todas as demais associações ligadas a esta área. Meus agradecimentos a todos. 


\section{TERCEIRA SESSÃO}

\section{O Judiciário na atual estrutura constitucional}

\section{Moderador: Bolívar Lamounier}

Expositores: Cláudio Lacombe

Mário Brockmann Machado

Plínio de Arruda Sampaio

\section{Bolivar Lamounier}

Iniciamos agora a discussão do último tema deste seminário, que é a posição do Judiciário na presente estrutura constitucional. Participarão desta sessão: o advogado Claudio Lacombe, o cientista político Mário Machado e o Dr. Plínio de Arruda Sampaio, ex-deputado federal. Peço ao Dr. Cláudio Lacombe que faça a sua exposição.

\section{Cláudio Lacombe}

O tema é a posição atual do Poder Judiciário na estrutura constitucional e as relações entre o Poder Judiciário e os outros poderes. Parafraseando o meu querido e saudoso amigo Otto Lara Rezende, posso dizer que o Judiciário está aonde sempre esteve: continua como titular do poder jurisdicional, o poder de jurisdicto, de dizer o Direito, de aplicar as leis. Dizia o Marquês de São Vicente que "forma o direito particular, a ordem civil que regula e compõe os interesses dos indivíduos entre si, na qualidade de particulares, e é o protetor dos direitos e interesses individuais da liberdade, da propriedade, da honra, da vida e de tudo que é caro aos homens como homens." A República ampliou esse poder extraordinariamente. A Constituição de 1891, inspirada na americana, atribuiu ao Judiciário uma prerrogativa de natureza eminentemente política, qual seja, o controle da constitucionalidade das leis e dos atos do governo. Investiu, portanto, o poder Judiciário no papel de árbitro na distribuição e equilíbrio dos poderes entre o Legislativo e o Executivo, bem como entre a União e os estados, e continuou como protetor da liberdade e dos direitos individuais e sociais assegurados pela Constituição. Essa função compete a todos os juízes, de modo geral, porque adotamos ainda no Brasil o controle concentrado e o controle difuso da constitucionalidade das leis. Mas o Supremo Tribunal Federal é a cúpula desse sistema, a que incumbe exercer o controle abstrato sobre a constitucionalidade das leis. E como é ele o titular da competência originária para julgar mandados de segurança, de injunção e habeas corpus contra atos ou omissões do presidente da República e do Congresso Nacional, creio que é sobre ele que deve se concentrar a atenção de quem vai examinar o tema ora em debate.

As funções políticas dos tribunais de justiça estaduais são insignificantes. O controle abstrato das constituições estaduais e das leis estaduais é exercido diretamente pelo Supremo Tribunal. E como a competência legislativa estadual é muito reduzida, é raro que os tribunais de justiça tenham que exercer qualquer função de natureza política. Cabe-lhes apenas declarar, no exercício desse poder de controle concentrado, a inconstitucionalidade das leis municipais. A anulação dos atos dos governadores e secretários de Estado em mandados de segurança e "habeas corpus" não tem sido fonte de atrito com o Poder Executivo, porque o descumprimento da decisão pode sujeitar o Estado à intervenção federal, com o desprestígio do Executivo estadual. E na cúpula, no plano federal, portanto, que surgem os problemas quando o STF, no exercício de suas atribuições políticas declarar a inconstitucionalidade das leis e dos atos dos outros dois poderes ou a ilegalidade desses atos - decreta a invalidade das leis e dos atos, frustrando a Como é fácil perceber, questões como essas têm um indisfarçável conteúdo político, envolvem valores e opções essencialmente políticas, são geradas por atritos inevitáveis provocados por confrontos de ideias, por choques de interesses, por razões de oportunismo, enfim, tudo o que há de conflito e que permeia o tecido das relações sociais submetidas ao ordenamento jurídico.

No Estado de Direito, esses antagonismos devem ser arbitrados pelos tribunais. Até hoje não se encontrou sistema melhor. Citando agora o ex-ministro Aliomar Baleeiro, "o Supremo Tribunal tem por missão precípua fazer prevalecer a filosofia política da Constituição sobre todos os desvios em que o Congresso, o presidente da República, estados e municípios e particulares se tresmalhem, quer por leis sancionadas, quer pela execução delas ou pelos atos naquela área indefinida de discricionarismo facultado, dentro de certos limites, àqueles poderes". Não há um traçado claro e inconfundível dos limites deste discricionarismo, quer contra o legislador, quer contra o executor das leis. Há uma "terra de ninguém", aí na faixa fronteiriça. Teoricamente, os limites estão na Constituição, mas esta nem sempre é clara. Então, cumpre ao Poder Judiciário interpretá-la para renovar, por exemplo, o alcance de dispositivos que pareçam envelhecidos, ou conservar aqueles que se deve manter estáticos segundo o espírito da Constituição, tal como interpretada pelo Tribunal. 
O Tribunal funciona assim: ora como freio, ora como acelerador. Tudo isso é político. Como dizia um juiz da Corte Suprema americana, Robert Jackson, "toda decisão que declara como o povo deve viver ou que atinja suas instituições tem sentido político". O Supremo Tribunal é, portanto, a expressão máxima de um poder político e assim, fatalmente, com os exemplos que relacionei, acaba por entrar em conflito com os outros dois poderes, conflitos de maior ou menor gravidade. Toda relação entre poderes políticos é tensa, são relações de tensão. Um famoso professor português, o Dr. Joaquim Canotilho, diz que "a Constituição é uma estrutura de tensões".

Tenho duas observações. Em primeiro lugar, esses embates e confrontos não resultam de iniciativas do Poder Judiciário, que é um poder passivo, só exerce a jurisdição quando solicitado pelas partes. Em segundo lugar, esses conflitos só aparecem em épocas de crise, seja ela política, econômica, social, militar. Quando o Judiciário é chamado a intervir, ele contraria - como não poderia deixar de ser uma das facções em luta, especialmente quando se opõe à mais poderosa.

Farei aqui um resumo das vicissitudes pelas quais passaram a Suprema Corte americana e o Supremo Tribunal Federal brasileiro, que ilustram o que acabo de dizer. A Corte Suprema americana teve uma atuação apagadíssima desde a sua criação até a nomeação do Chief Justice Marshall por Adams, no final de seu governo, em janeiro de 1801. Ela foi instalada em 1790 e até a nomeação de Marshall só tinha julgado 55 casos. Marshall lutara na Guerra da Independência, tivera uma missão diplomática temporária. Era um especulador de terras e foi deputado. Nunca fez curso jurídico regular, teve apenas dois meses de aula para poder exercer a advocacia. E foi ele, sem dúvida alguma, o artífice do prestígio que a Corte Suprema americana desfruta até hoje, como autor da doutrina da supremacia judicial, que permitiu a ela declarar a inconstitucionalidade das leis. A decisão pioneira, como se sabe, foi no famoso caso Marbury versus Madison, que provocou uma reação imediata do presidente Jefferson, que a considerou atentatória ao princípio da separação dos poderes. Marbury fora nomeado juiz de paz para o Distrito de Colúmbia, por Adams.

Madison, secretário de governo de Jefferson, governo que sucedeu ao de Adams, negou-lhe a posse. Marbury então requereu uma ordem de mandamus contra Madison à Corte Suprema. Habilmente, Marshall declarou ilegal o ato de Madison, mas entendeu que não podia deferir o mandado porque a lei judiciária de 1789, que atribuiu à Corte competência originária para julgar aquele tipo de caso, era inconstitucional. Foi então que ele desenvolveu a tese pioneira da invalidade ou nulidade da lei contrária à Constituição. A imprensa e o Congresso, inspirados por Jefferson - que, aliás, detestava Marshall -, antes mesmo da decisão já ameaçavam a Corte com o impeachment de seus juízes se eles concedessem a ordem. Depois do julgamento, Jefferson passou imediatamente à ação, promoveu o impeachment do Justice Samuel Chase, acusado de facciosismo, de conduta arbitrária e até mesmo de desonestidade, acusações que aparentemente eram todas verdadeiras.

Mas não se atingiu no Senado o quórum para a decretação do impeachment, que ninguém naquela época tinha dúvida de que era um prelúdio do impeachment do próprio Marshall. Esse foi o grande perigo que a Corte passou nesse período, até 1835. Depois de Jefferson veio o presidente Jackson, que descumpriu uma decisão da Corte, que concedera um habeas corpus contra uma autoridade estadual. Expedido o mandado, o Estado se recusou a cumpri-lo; pediu-se a intervenção federal e o presidente Jackson respondeu: "John Marshall que o escreveu e assinou, que vá cumpri-lo". A crise daquela época era a da consolidação da Federação, ou melhor, era a crise da supremacia da União, objetivo principal de Marshall, contra o qual reagiam os estados que defendiam a Confederação, apoiados até, a meu ver, na letra da Constituição.

O grande problema da segunda etapa da história do tribunal foi a escravidão. A partir de 1850, a campanha abolicionista começou a empolgar a opinião pública e a Corte se viu envolvida no conflito entre o Norte e o Sul. As fugas de escravos provocaram decisões favoráveis aos estados do Sul, abertamente descumpridas pelos estados do Norte. E a imprensa e o Congresso desfechavam críticas virulentas contra esses julgamentos. O momento culminante foi quando a Corte negou um habeas corpus ao escravo Dred Scott, declarando a sua ilegitimidade para requerer em Juízo por não ser cidadão, por não ser sujeito de direitos. Essa decisão foi um momento de grande desprestígio para a Corte, chamada pela imprensa e pelo Congresso como "a cidadela da escravidão". Muitos historiadores, aliás, acham que o julgamento foi uma das causas próximas da Guerra Civil. Entre outros problemas, a decretação por Lincoln, por exemplo, da suspensão da garantia do habeas corpus foi considerada inconstitucional, mas a decisão não foi cumprida. Já depois da Guerra, a decisão do caso Millingan, subtraindo os civis à jurisdição das cortes militares, apesar dos protestos a ela dirigidos, foi obedecida.

No período seguinte, que vai até 1937 , consolida-se a instituição do que se denominou, até pelo escritor francês Eduard Lambert, "o governo dos juízes", em que a Corte se caracterizou, apesar da dissidência de alguns de seus principais juízes, 
como Holmes, Brandeis, Frankfurter, Benjamin Cardozo, por um conservadorismo pétreo, diria melhor, um reacionarismo monstruoso. Utilizando a cláusula do "due process of law", o Tribunal reagiu contra toda a legislação social, considerando inconstitucional a fixação de horários de trabalho, a associação sindical, negando a aplicação da lei antitruste às empresas, mas curiosamente aplicando a lei antitruste e considerando uma manifestação de abuso do poder econômico a União dos Chapeleiros, declarando inconstitucional as leis de fixação de tarifas de serviços públicos. Culminou isso tudo - a decisão que mais provocou protestos - com aquela que declarou a inconstitucionalidade da primeira lei do imposto de renda. Houve aí uma tentativa, no Congresso, de estender o "recall", quer dizer, a remoção dos ministros da Corte Suprema pelo Congresso, ou então de revogação das decisões da Corte Suprema contrárias à Constituição. Esse projeto não passou.

Entre 1933 e 1936 a Corte torpedeou o "New Deal" de Franklin Roosevelt, declarando a inconstitucionalidade total e parcial das diversas leis em que se apoiava o programa, num total de 12 julgamentos. Aí houve uma reação violentíssima do presidente, que passou a bombardear a Corte quase que diariamente nos seus programas de rádio e no Congresso. Em 1937 Roosevelt propôs ao Congresso uma reforma do Judiciário, nela incluindo a modificação da composição da Corte, disfarçada numa proposição de caráter geral: a nomeação de juízes adicionais em todos os tribunais federais onde magistrados, ao atingirem 70 anos, não pedissem aposentadoria ou demissão.

Nessa ocasião, a Corte tinha seis juízes com mais de 70 anos. Nesse episódio é que se vê como era, e é até hoje, arraigada a devoção do povo americano à Corte Suprema. De todos os pontos do país, surgiram protestos contra o projeto. O Congresso resolveu fazer uma pesquisa de opinião, foram distribuídos $140 \mathrm{mil}$ questionários e a maioria esmagadora das respostas desaprovou o aumento do número de juízes. Foi a própria Corte que recuou e a partir de 1937 modificou sua jurisprudência, acabando com a crise. Daí em diante não houve mais conflitos capazes de gerar uma ruptura institucional. Houve críticas à jurisprudência mais recente, em favor das minorias raciais e religiosas e do aborto, mas que não abalaram o prestígio da Corte; muito ao contrário, aumentaram-na.

No Brasil a história é parecida. A crise surgiu no primeiro período de funcionamento do Tribunal, na ditadura de Floriano Peixoto. O primeiro habeas corpus foi requerido por Rui Barbosa em favor das vítimas do Estado de Sitio decretado em 1892, que foi negado. Já o segundo, em favor dos civis que se encontravam no vapor Júpiter, que foi tomado pelo almirante Vandelkok, no Rio da Prata, para intervir na Revolução Federalista do Rio Grande do Sul, foi concedido. Mas só foi cumprido porque a maioria dos passageiros era de americanos, alemães e espanhóis e anunciou-se que as embaixadas desses países iam protestar em conjunto se o governo resistisse à ordem judicial. Floriano reagiu de outra maneira: deixou o Tribunal praticamente parado durante quase um ano, não preenchendo as vagas que ali ocorreram. Em 1893, nomeou um médico como ministro do Tribunal, que ali ficou durante dez meses - um médico até muito ilustre, Barata Ribeiro -, até que o Senado desaprovasse a sua nomeação. Nomeou também dois generais, Inocêncio Galvão de Queiroz e Raimundo Everton Quadros, cuja indicação também foi rejeitada pelo Senado. Floriano deixou de cumprir a ordem de habeas corpus de 22 de setembro de 1894, concedida aos militares reformados que embarcaram na aventura do navio Júpiter para que não fossem processados na Justiça Militar.

O governo de Prudente de Morais foi mais tranquilo. Mas com o assassinato do ministro da Guerra, general Machado Bittencourt, que defendeu Prudente de Morais no atentado de 5 de novembro de 1897, o governo pediu e obteve o Estado de Sítio e desterrou para a Ilha de Fernando de Noronha diversos parlamentares. Em 16 de abril de 1898 o Supremo Tribunal concedeu-lhes habeas corpus, impetrado por Rui Barbosa, acolhendo a tese de que as imunidades parlamentares não se suspendem pelo Estado de Sítio. Houve uma agressiva reação de Prudente de Morais e da imprensa governista.

Segue-se um período de tranquilidade até o governo do Marechal Hermes, que em 1911 se recusou abertamente a cumprir uma ordem de habeas corpus expedida em favor dos intendentes da Câmara Municipal do Rio. Daí até 1930 só houve uma crise grave, em 1927, quando foi concedido habeas corpus a Raul Fernandes para assumir o governo do Estado do Rio. A eleição de Raul Fernandes fora contestada por uma assembleia que se dizia eleita e que reconhecia como governador o major Feliciano Sodré, que tinha o apoio do Governo Federal. A concessão da ordem provocou uma grande anarquia, em Niterói, alimentada pelo Governo Federal, que decretou a intervenção federal no estado para não cumprir o acórdão. E Raul Fernandes renunciou.

Cada crise tem os ingredientes da época de sua eclosão, quase sempre de natureza política, econômica, provocada por fundamentalismo religioso, pelo radicalismo ideológico e até mesmo por razões de ordem pessoal, como às vezes ocorre no nosso regime, por fraqueza ou incompetência do Presidente da República. As primeiras escaramuças, como se viu, ocorreram na fase inicial da República, no 
período de sua consolidação, sob uma ditadura eventual. As outras que surgiram, e que não foram tão graves, na década de 1920, quando imperava uma certa desordem, uma desordem institucional em consequência da pobreza dos quadros políticos, da ausência de substrato ideológico dos partidos. Essas crises eram realmente resultado do mandonismo de caciques locais, das rivalidades entre as oligarquias estaduais, da influência de "coronéis" e de caudilhos (como Pinheiro Machado).

O que se verificou em 1930, com a aposentadoria compulsória de seis ministros que haviam se manifestado contra os revolucionários de 1922, 1923, 1924 e 1925 não interessa, a meu ver, ao debate aqui, porque a medida foi tomada em momento de colapso da ordem jurídica. Getúlio cassou, revogou por decreto duas decisões do Supremo Tribunal, além da violência que foi a aposentadoria compulsória dos mesmos. Tampouco interessa ao presente debate o que ocorreu na vigência do AI-5, quando foram aposentados os ministros Victor Nunes Leal e Evandro Lins e Silva.

De maior interesse para o tema em debate é investigar as razões dessa crise latente entre o Judiciário e os outros poderes. Dizia o ministro Aliomar Baleeiro, em seu estilo pitoresco: "As pessoas desconfiam de homem que usa saia". Um cientista político americano disse, por sua vez, que a Corte Suprema é a instituição nacional mais venerada e a menos conhecida e compreendida.

O Poder Judiciário é realmente de tal maneira específico, mesmo no desempenho de sua função política - acho bom que assim seja -, que as suas relações com os outros poderes serão sempre, a meu ver, na melhor das hipóteses, cerimoniosas. Os poderes Executivo e Legislativo são exercidos por artesãos do mesmo ofício, cujas disputas levantam poeira, mas não causam abismos; são formados na escola da negociação, da composição, do temor reverencial à opinião pública e, como esta é volúvel, eles também são inconstantes, o que é compreensível. Além disso, eleitos direta ou indiretamente, consideram-se ungidos pela manifestação da vontade popular, consideram-se dotados de uma legitimidade superior à dos juízes. Da mesma forma, nos Estados Unidos, existem críticas dos políticos à Suprema Corte, vista como um órgão não eletivo que às vezes tem a pretensão de intervir na política através de pessoas responsáveis apenas perante a própria consciência. Jefferson dizia que a Corte era um órgão irresponsável ("irresponsable power"). A oposição do Tribunal às leis, projetos e atos aprovados pelas assembleias legislativas parece aos políticos uma atitude antidemocrática, a opressão de uma minoria sobre a maioria. No entendimento dos políticos, ainda que esse entendimento nem sempre seja claramente formulado, aquela que é a garantia mais eficaz de todos os cidadãos contra o arbítrio de um poder, ou seja, a liberdade de consciência dos juízes, é às vezes visto como um álibi para a indiferença dos magistrados para com as aspirações do povo. Um caso recente parece-me exemplar: a reação do Congresso, com o apoio da imprensa e do governo, ao resultado do primeiro julgamento do mandado de segurança do presidente Collor contra a decisão do Senado, que decretou o seu impeachment. Os senhores sabem, está na memória de todos que se verificou um empate no primeiro julgamento. Esse empate foi tomado como um ato de falta de patriotismo; a meu ver, demonstrou que cada ministro votou de acordo com a sua consciência porque, nenhum deles tinha interesse em que houvesse um empate, que a decisão fosse desempatada por ministros do Superior Tribunal de Justiça. Parece- me, portanto, que os políticos reagem instintivamente contra esses cavalheiros que vestem saias pretas, que não compõem, não negociam, falam uma linguagem hermética, não respondem às aspirações populares, não têm compromisso com o mérito das leis ou programas de governo, mas apenas com a concepção que têm do Direito, expresso pela Constituição e que, a meu ver, não é tão sagrada para os políticos como o é para os magistrados, porque eles (políticos) têm em suas mãos o poder de alterar essa Constituição, respeitada a opinião pública.

Por isso, concluindo, acho que as relações entre o Poder Judiciário e os demais poderes foram, são e continuarão a ser relações de tensão, que podem chegar ao ponto de ruptura conforme a gravidade das crises institucionais em que esse conflito se verificar. É este o argumento que desejava trazer a este seminário. Obrigado a todos pela atenção.

\section{Bolívar Lamounier}

Nossos agradecimentos ao Dr. Lacombe por esta importante exposição. Passo em seguida a palavra ao Dr. Mário Machado.

\section{Mário Brockmann Machado}

Agradeço ao IDESP, nas pessoas do professor Bolívar Lamounier e da professora Maria Tereza Sadek o convite para participar desta reunião.

Dentre os muitos problemas suscitados pelas relações entre os poderes da República, decidi abordar um deles, que é o do controle externo do Poder Judiciário. Quero dizer, desde logo, que sou favorável a esse controle externo. Sei que o tema é bastante controverso e delicado. A própria pesquisa da professora Maria Tereza Sadek mostra que $86 \%$ dos juízes consultados se manifestaram 
contrários à existência de um controle externo do Poder Judiciário. Sei, portanto, que estou pisando em terreno bastante sensível.

\section{Passarei à leitura do texto que preparei para este seminário:}

As relações entre os chamados "poderes da República" suscitam um grande número de questões importantes. Uma delas é a proposta de controle externo do judiciário, intensamente criticada pelos membros desse poder.

O discurso dos que se opõem a esse controle é costumeiramente baseado no princípio da separação de poderes. Penso, ao contrário, que interesses institucionais estão no cerne dessa objeção. Neste artigo, porém, decidi tomar tal discurso a sério, e argumentarei que, ao contrário do que se afirma, o controle externo do judiciário é não apenas compatível, como também requerido, pelo princípio da separação de poderes.

Farei isso mostrando que, para os autores clássicos na matéria, o objetivo da separação é a limitação dos poderes (razão porque vem associada a diversos mecanismos de controle mútuo), e não o isolamento e a expansão independente desses poderes.

Para tanto, abordarei de forma resumida o pensamento de Locke, de Montesquieu e dos constituintes norte-americanos, finalizando com breve comentário sobre a situação brasileira ${ }^{2}$

\section{LOCKE}

Historicamente, o princípio da separação de poderes se apresenta como fórmula de enfraquecimento do poder real absoluto ${ }^{3}$.

\footnotetext{
${ }^{2}$ As citações que se seguem tomaram por base tanto os textos originais, especificados abaixo, quanto as traduções apresentadas por Leonel Itaussu Almeida Mello, J. A. Guilhon Albuquerque e Fernando Papaterra Limongi in Francisco Weffort, org. Os Clássicos da Política. São Paulo, Ática, 1989, $1^{\circ}$ volume. Os autores clássicos referidos não são, por suposto, os únicos a tratarem do tema. Kant, por exemplo, o abordou em sua Metafísica dos Costumes. Mas são os que maior influência tiveram sobre o pensamento constitucional moderno.

A discussão sobre relevância ou inutilidade de se estudar os chamados textos clássicos, bem como a sua própria identificação, atingiu nos últimos anos uma intensidade extraordinária. Para uma visão de conjunto atualizada sobre o tema, ver Arlene W. Saxonhouse, "Texts and Cannons: The Status of the Great Books in Political Theory." In Ada W. Finifter, Ed Political Science: The State of Disciplane II. Washington, D.C: The American Political Science Association, 1993, pp. 3-26"

3 O Primeiro Tratado de Locke tinha como objetivo de contestar o livro de Robert Filmer, Patriarcha, que defendia a monarquia absoluta. As citações que se seguem são do Tratado. John
}

Refletindo sobre a história de seu país, Locke identifica dois poderes fundamentais: o de fazer leis, o legislativo; e o de executá-las, de fazêlas obedecidas, se necessário com o auxílio da força, que é o executivo. O judiciário não é destacado, ficando suas funções distribuídas entre aqueles dois. Locke fala ainda de um terceiro poder o de fazer a guerra e a paz nas relações exteriores, chamado de "federativo", mas entende que, na prática, ele deva ficar nas mãos do executivo ${ }^{4}$.

O legislativo é visto como o principal poder do governo, mas é, por sua vez, subordinado ao poder supremo do povo na sociedade, que pode afastá-lo ou modificá-lo, se agir contrariamente ao encargo que lhe foi confiado, o mesmo valendo para o executivo. E quem decidirá se os poderes do governo agem em desacordo ao encargo recebido? "A isto respondo: o povo será o juiz", conclui o autor ${ }^{6}$.

Resumindo, portanto: o judiciário não está separado dos outros poderes; destes, o legislativo é o superior; mas todos estão subordinados ao consentimento popular Assim, o princípio da separação de poderes em Locke não fundamenta a tese da independência do judiciário.

\section{MONTESQUIEU}

Montesquieu trata da separação de poderes na parte de seu livro dedicada ao estudo "Das leis que formam a liberdade política em sua relação com a constituição" ". Não se trata, portanto, de uma discussão abstrata sobre como organizar o governo, mas sim de como melhor garantir a liberdade dos indivíduos contra os abusos de poder Para tanto, "é preciso que, pela disposição das coisas, o poder contenha o poder" ${ }^{8}$, pois a liberdade estaria perdida "se o mesmo homem, ou o mesmo corpo de notáveis, ou de nobres, ou do povo, exercesse esses três poderes: o de fazer as leis, o de executar as decisões públicas, e o de julgar os crimes ou as pendências entre particulares" 9. A influência inglesa no pensamento de Montesquieu,

Locke, Two Treatises of Government. Edited by Peter Laslett. Cambridge: Cambridge University Press, 1960

${ }^{4}$ Os três poderes são apresentados no capítulo XII, parágrafos 143 a 148.

${ }^{5}$ Capítulo XII, parágrafos 149 a 151, e capítulo XIX, parágrafo 243. A superioridade do legislativo era o princípio geral, mas situações especiais poderiam justificar o fortalecimento do executivo ("prerrogativas", parágrafos 158, 159 sgs.). O pensamento de Hobbes não podia ser ignorado.

${ }^{6}$ Capítulo XIX, parágrafo 240.

${ }^{7}$ Montesquieu, De L'Esprit dês Lois. Avec des notes de Voltaire, de Crevier, de Mably, de La Harre, etc. Paris, Garnier, s.d. (1927?).

${ }^{8}$ Ibid., p. 151 .

${ }^{9}$ Ibid., p. 152 
como se sabe, é muito forte, e não por acaso a citação acima foi extraída do capítulo de seu livro que trata "Da Constituição da Inglaterra" ${ }^{10}$.

Isto dito, passa o autor afazer uma análise do judiciário. Afirma que "o poder de julgar não deve ser atribuído a um senado permanente, mas sim exercido por pessoas extraídas do corpo do povo, em certos períodos do ano, da maneira prescrita pela lei, para formar um tribunal que dure apenas o tempo requerido pela necessidade ${ }^{11}$. Desse modo, continua, o poder de julgar, tão terrível entre os homens, não estando ligado nem a um certo grupo social, nem a uma certa profissão, torna-se, por assim dizer invisível e nulo" ${ }^{12}$. Finalmente, afirma ser preciso "que os juízes sejam da condição do acusado, ou seus pares...". ${ }^{13}$

Notem bem: o poder de julgar nem é permanente, mas temporário, nem é exercido por profissionais, mas pelo próprio povo. E não sem impiedade conclui Montesquieu: "Dos três poderes de que falamos, o de julgar é de certo modo nulo. Restam apenas dois", referindo-se ao legislativo e ao executivo14.

Na sequência, argumenta Montesquieu que o executivo deve ficar nas mãos de um só, o monarca, enquanto que o legislativo, dividido em duas casas, deve ser confiado tanto ao corpo dos nobres, quanto ao que será escolhido para representar o povo ${ }^{15}$.

É dessa nova tripartição de poderes que Montesquieu então se ocupa sugerindo diversos mecanismos de controle mútuo, para assim finalizar: "Eis aqui, portanto, a constituição fundamental do governo de que estamos falando. Estando o corpo legislativo composto de duas partes, uma conterá a outra por sua recíproca faculdade de vetar Ambas serão limitadas pelo poder executivo, que será, por sua vez, limitado pelo legislativo. Esses três poderes, segue o autor, deveriam formar um repouso ou uma inação. Mas como, pelo movimento necessário das coisas, são obrigados a caminhar serão forçados a caminhar de comum acordo." 16

${ }^{10}$ Trata-se do capítulo VI do livro XI

${ }^{11}$ Ibid., p.153. Interessante notar que o autor utiliza a expressão "puissance de juger", e não "pouvoir de juger".

${ }^{12}$ Ibid., p.153. O autor usa o termo "état", aqui traduzido por "grupo especial".

${ }^{13}$ Ibid., p.154. O princípio do julgamento pelos pares é muito antigo, podendo ser encontrado na Magna Carta de 1215, item 48: "Ninguém poderá ser detido, preso ou despojado de seus bens, costumes e liberdades, senão em virtude de julgamento de seus Pares segundo as leis do país".

${ }^{14}$ Ibid., p. 156

${ }^{15}$ Ibid., p. 156

${ }^{16}$ Ibid., p. 160.
Fica, portanto evidente que o objetivo da separação de poderes, acrescida dos mecanismos de controle mútuo, é a sua limitação, e não a sua independência.

Ademais, além de excluir o judiciário da formulação final de sua proposta de engenharia política, Montesquieu ainda atribui ao legislativo competência para julgar em algumas situações especiais. Assim, alegando, como já se viu, que os réus devam ser julgados por seus pares, recomenda "que os nobres sejam levados a julgamento não diante dos tribunais ordinários da nação, mas diante daquela parte do corpo legislativo composta pelos nobres" ${ }^{17}$.

Com todas essas restrições, não é possível encontrar em Montesquieu a raiz histórica de um judiciário poderoso e independente.

\section{O FEDERALISTA}

Onde o judiciário aparece claramente como um poder separado do executivo e do legislativo é na Constituição dos Estados Unidos. E a melhor fonte de informação sobre os debates em torno da aprovação daquele documento legal é o conjunto de artigos publicados na imprensa da época por Alexander Hamilton, James Madison e John Jay, que passo a $\operatorname{citar}^{18}$

Madison começa admitindo que a acumulação dos poderes legislativo, executivo e judiciário nas mesmas mãos, seja de um, de poucos ou de muitos, por razões hereditárias, de autoindicação ou eletivas, constitui tirania. Assim, a preservação da liberdade exige a separação dos poderes ${ }^{19}$

Nesse sentido, Madison ressalta, explicitamente, os ensinamentos de Montesquieu, bem como a influência da experiência política inglesa. E nota que esta última não apresenta poderes totalmente separados e distintos uns dos outros, já que vários são seus mecanismos de controle e suas atividades conjuntas ${ }^{20}$. Esse fato, argumenta Madison, está em

${ }^{17}$ Ibid., p.159. Essa última recomendação de Montesquieu nos mostra como sua reflexão conjuga duas ordens distintas de problemas: de um lado, a separação de poderes propriamente dita; e de outro, o governo misto e a atribuição de instituições governamentais diferenciadas a atores políticos poderosos: a realeza, a nobreza e a burguesia. Voltarei a este ponto logo adiante no texto.

${ }^{18}$ The Federalist. Introduced by William R. Brock. London, J.M. Dent Ltd, 1992. A Editora Nova Fronteira traduziu e publicou esses "artigos federalistas" em 1993. Ver também Max Ferrand, The Records of the Federal Convention of 1787. New Haven: Yale University Press, 1966.

${ }^{19}$ Federalista $n^{\circ} 47$, p. 247. Esta passagem deixa claro que, para a tradição liberal, pode haver tirania até mesmo na democracia, se os poderes forem acumulados nas mãos dos "muitos", ainda que eleitos.

${ }^{20}$ Ibid, p. 247-248 
perfeita consonância com as recomendações de Montesquieu - baseadas, aliás, no próprio exemplo britânico -, já que o filósofo francês não confunde separação com independência, conforme já vimos anteriormente. Por essa razão, Madison argumenta que os poderes devem estar "conectados e reunidos", de tal forma a dar-se a cada um o controle constitucional dos outros ${ }^{21}$.

E por que não basta a simples separação de poderes? Porque, raciocina Madison, o poder é naturalmente usurpador, devendo por isso ser eficazmente impedido de ultrapassar os limites que lhe forem definidos $^{22}$. Donde a necessária conclusão de que a estrutura interna do governo deve ser tal que suas diversas partes constituintes possam, por suas relações mútuas, ser os instrumentos que mantenham cada uma delas em seus próprios lugares ${ }^{23}$. Como resumia Montesquieu, "é preciso que, pala disposição das coisas, o poder contenha o poder".

Muitos e variados são, como se sabe, esses mecanismos de controle mútuo: o legislativo vota as leis, mas o executivo tem o poder de veto; o executivo elabora seu orçamento, mas quem o aprova é o legislativo; o executivo nomeia os ministros da corte suprema, mas só depois de aprovados pelo senado; o senado julga o impeachment tanto do chefe do executivo, quanto dos ministros da corte suprema, etc. Em suma: separação sim, mas não independência de poderes.

Com relação ao judiciário propriamente dito, havia muita resistência à criação de uma corte suprema como sua última instância. A tradição inglesa, que atribui tal função à Câmara dos Lordes, sugeria que ao novo senado fosse delegada essa responsabilidade. A principal razão da objeção era o perigo de que a corte suprema, caso fosse dotada de competência para declarar a inconstitucionalidade das leis, usurpasse poderes do legislativo.

Contra essa posição, Hamilton argumentava que tal poder do judiciário não era ilimitado, e nem poderia basear-se na interpretação do "espírito" da Constituição ${ }^{24}$. Ao contrário, somente poderiam ser anulados atos do legislativo "contrários ao manifesto teor da Constituição" ${ }^{25}$. Em outras palavras: tal poder do judiciário só poderia aplicar-se a casos de "divergência irreconciliável" ${ }^{26}$ e "evidente oposição" entre a lei e a Constituição ${ }^{27}$.

Além disso, a justificativa para esse procedimento não era a superioridade do judiciário sobre o legislativo, mas a superioridade da Constituição sobre as leis. A Constituição é a vontade do povo, argumentava-se, enquanto que a lei é a vontade do legislador; donde a necessária hierarquia legal ${ }^{28}$.

De qualquer forma, lembrava Hamilton, sempre restaria ao legislativo o poder de fazer o impeachment dos ministros da corte suprema - garantia de que seus poderes não seriam usurpados impunemente ${ }^{29}$

Ao fim e ao cabo, tal princípio não foi incorporado à Constituição, mas foi apesar disso fixado pela Suprema Corte em 1803, em marcante julgamento, permanecendo para sempre como tema gerador de fortes controvérsias.

Finalmente, cumpre lembrar que a discussão sobre separação de poderes nos Estados Unidos não mais se confundia com a questão do governo misto, ao contrário do que ocorria na Europa, como nos escritos de Locke e Montesquieu. Pois o novo país não tinha realeza e nobreza com que partilhar suas instituições políticas. A preocupação com a limitação do poder central resultava das condições estabelecidas pelos antigos Estados, fortemente autônomos, para entrarem na nova federação. A liberdade buscada, portanto, não era apenas dos cidadãos, mas também dos Estados que se uniam - os Estados Unidos. Donde a fragmentação do poder com base na engenharia política disponível, ainda que a realidade sociológica do país fosse outra.

\section{BRASIL}

Abordando brevemente o caso brasileiro, sabemos que a República sofreu forte influência constitucional norte-americana - a começar pelo novo nome político que lhe deu Rui Barbosa: Estados Unidos do Brasil. Assim, por exemplo, a Constituição de 1891 fortaleceu grandemente o judiciário, e a apresentou como um dos três poderes "harmônicos e

\footnotetext{
${ }^{21}$ Federalista $n^{\circ} 48$, p. 253

22 Ibid, p. 253, 257.

${ }^{23}$ Federalista $^{\circ}{ }^{\circ}$ 51, p. 265.

${ }^{24}$ Federalista no 81, p. 414

${ }^{25}$ Federalista $^{\circ}$ 78, p.399
}

${ }^{26}$ Ibid, p.400.

${ }^{27}$ Federalista $^{\circ}$ 81, p.414.

${ }^{28}$ Federalista $^{\circ}$ 78, p.401

${ }^{29}$ Federalista n $^{\circ} 81$, p.416, e n ${ }^{\text {o }} 79$, p.406. 
independentes entre si”, disposição que foi mantida por todas as Constituições posteriores, exceto a de $1937^{30}$

Apesar de seus aspectos positivos, essa influência, no entanto, era duplamente artificial: nem tínhamos realeza e nobreza para acomodar institucionalmente, posto terem sido aposentadas pela República; nem tínhamos que lidar com autonomias estaduais, já que as antigas Províncias faziam parte de um Império unitário. Dessa maneira, tomou-se a engenharia política requerida pelas características especiais de outras sociedades como se fossem dogmas de valor universal e atemporal.

Além disso, a expressão "poderes independentes" permite uma interpretação abusiva da teoria inspiradora da fórmula importada, pois o que se busca com a separação de poderes é a sua limitação mútua, enquanto que o que se obtém com a sua independência é uma lógica de expansão isolacionista. E com o isolamento podem vir a irresponsabilidade, o privilégio e o abuso.

\section{CONCLUSÃO}

Como é muito mais seguro e menos trabalhoso ser elite por decreto, como maliciosamente anotava Antonio Gramsci, é compreensível que os principais atores políticos desejem obter o status de Poder da República. Da mesma maneira, entende-se que os atores que tenham de fato alcançado essa posição sejam inclinados a congelar o mercado político, de tal forma não apenas a conservar permanentemente a vitória obtida mas também a impedir a entrada de novos atores que possam representar concorrência ou ameaça.

A teoria da separação de poderes, acertadamente ou não, reconheceu a existência de três poderes. Ao longo da história brasileira, como se sabe,

${ }^{30}$ Também atribuiu-se competência ao judiciário para julgar a inconstitucionalidade das leis. O judiciário do Império não tinha essa competência, e, além disso, não conseguia controlar o contencioso administrativo, que retirava de sua apreciação as grandes causas públicas. E o Senado passou a julgar o impeachment dos ministros do Supremo Tribunal por crimes de responsabilidade. Para uma interessante documentação da permanência das ideias constitucionais de Rui Barbosa, ver Vicente Barreto, O Liberalismo e a Constituição de 1988: textos selecionados de Rui Barbosa. Rio de Janeiro, Nova Fronteira, 1991.

Além das mudanças acima referidas, a República, extinguindo o poder moderador, adotou a federação, o presidencialismo, a eleição direta do presidente e dos governadores, e ainda por cima teve sua Constituição aprovada por uma constituinte! É incompreensível, diante da magnitude dessas transformações institucionais, que ainda haja quem pense a República como um simples golpe militar (Essa versão, não por acaso, foi difundida pela propaganda monarquista durante o recente plebiscito.). outros atores tentaram conquistar essa posição. O imperador, que detinha o poder moderador Os militares, que, na República, tentaram ser os herdeiros desse poder moderador Os economistas, quando argumentam que a., questões econômicas são de natureza técnica, e que por isso não deveriam ser submetidas à discussão pública e à deliberação do legislativo (como durante os governos militares, ou quando dos "pacotes econômicos", ou ainda quando propõem um Banco Central "independente"). E, mais recentemente, o Ministério Público, que vem transformando-se em quarto poder da República.

O princípio da separação de poderes é sábio, mas a identificação dos poderes a serem separados, o grau de sua autonomia, o tempo de permanência de cada um nesse status, e os mecanismos de controle mútuo são questões de natureza política geralmente resolvidas por meio de conflitos de intensidade elevada.

Hoje, um dos temas importantes da agenda política do país é a proposta de controle externo do judiciário.

Espero haver demonstrado, apesar da brevidade da exposição, que nada há no princípio da separação de poderes que desaconselhe, nem muito menos impeça, esse procedimento. Ao contrário: na tradição do pensamento liberal, separação não significa independência, pois cada poder deve controlar os demais.

Nem tampouco poderia a resistência a esse controle encontrar argumentos na tradição do pensamento democrático, pois, para este, qualquer que seja o status desses poderes, nenhum é independente em relação à cidadania soberana.

Em outras palavras: ou bem o judiciário é um poder da República, e neste caso não pode ser independente do soberano, que é a cidadania; ou é simples função técnica especializada (como a militar, a diplomática, a econômica, etc.), e neste caso não é um poder da República, podendo realizar-se no âmbito, por exemplo, do Ministério da Justiça (donde a ideia de um "poder técnico" ser ou simples nonsense, ou justificativa ideológica para um status político imerecido) ${ }^{31}$.

\footnotetext{
${ }^{31}$ Veja-se, por exemplo, esta arrogante defesa do judiciário feita por um destacado advogado do Rio de Janeiro: "Me repugna a ideia de um Poder Judiciário responsável perante a opinião pública; ele é um poder técnico, e tem que ser independente para melhor interpretar a lei". O Globo, 19 de setembro de 1993, p.10 (mesa-redonda "A Constituição em Debate").
} 
Em suma: a defesa radical da independência do judiciário não se baseia no princípio da separação de poderes, e nem encontra guarida nas tradições liberal e democrática. Deve-se, ao contrário, à simples defesa de interesses institucionais por parte de seus membros, que se constituem em um dos mais articulados e bem sucedidos grupos de pressão do sistema político brasileiro.

Portanto, o legislativo, no exercício de sua competência, pode e deve estabelecer seu controle sobre o judiciário, a exemplo do que já exerce em relação ao executivo ${ }^{32}$.

\section{Bolivar Lamounier}

Agradeço em nome de todos ao Dr. Mário Machado por esta substanciosa reflexão e com muito prazer passo a palavra ao D. Plínio de Arruda Sampaio.

\section{Plínio de Arruda Sampaio}

Acho que tenho que primeiro explicar por que estou aqui, porque eu talvez não devesse estar. Eu estudei Direito há... nem conto de tanto tempo. Acho que estou aqui porque fui relator do capítulo do Poder Judiciário na Constituinte, isto é, porque eu me atrevi a aceitar o convite que me foi feito pelo Dr. Ulysses Guimarães para essa função. O político, como sabemos, é um especialista em ideias gerais. Antes de vir a este seminário, eu estava noutro, sobre problemas da educação. Quando sair daqui, eu vou a uma discussão sobre cenários possíveis do Brasil em 1994. Como percebem, o político na verdade não sabe nada em particular. Assim, por favor, tenham paciência com o que vou dizer.

\section{Cláudio Lacombe}

O político não sabe, mas desconfia

\section{Plínio de Arruda Sampaio}

Desconfia muito. É um especialista nisso. Então eu queria começar com uma observação do Lacombe: o Judiciário está onde sempre esteve e isso é uma pena. É uma pena porque a Constituinte (1987-1988) perdeu uma oportunidade

${ }^{32}$ A Constituição de 1988 (art.49, X) estabelece a competência do Congresso para "fiscalizar e controlar, diretamente ou por qualquer de suas Casas, os atos do Poder Executivo, incluídos os da administração indireta". histórica importante e acho que vamos perder outra agora na revisão constitucional em curso, porque essa revisão é isso que vocês veem aí.

O ponto fundamental, que foi aqui citado tanto pelo Mário Machado como pelo Cláudio Lacombe, é que, na democracia, o poder controla o poder. Só o poder controla o poder. Não há nada mais que controle o poder, senão o próprio poder. E o controle de qualquer poder sobre os outros poderes é a garantia dos nossos direitos. Para que os nossos direitos sejam respeitados é preciso que o poder controle o poder. Nossos direitos são desrespeitados toda vez que um cidadão anda a 150 quilômetros na rua e nos causa um risco danado. Toda vez que um vizinho avança o muro em cima do nosso terreno, toda vez que alguém prejudica o nosso direito. É verdade isso, mas esses são casos particulares. Não reside aí a fonte mais importante de violação dos nossos direitos. Quem mais viola, e mais profunda e perigosamente o nosso direito, são os outros poderes. $\mathrm{Ou}$ é o Legislativo, com uma lei iníqua, muitas vezes feita por propósitos subalternos, ou o Executivo, com a prepotência da força de quem detém o poder financeiro e o poder da violência, da coerção. Essa é a ameaça séria e real ao nosso direito e é por isso que temos o controle da constitucionalidade, tanto das leis como dos atos.

É por isso que na Constituição nós quisemos - digo nós porque foi um grupo numeroso e bem assessorado, eu não me atreveria a propor sozinho um artigo da Constituição sobre o Judiciário - o que nós quisemos fazer foi reservar para o tribunal mais importante do país a competência constitucional. O Supremo seria um tribunal dedicado apenas a questões constitucionais. Por quê? Porque o nosso hoje cuida de coisas diversas, e assim não tem tempo para julgar rapidamente as questões constitucionais. O "seu" Collor está processado e o STF não tem tempo, porque antes tem um recurso, outro recurso, etc. Então, quisemos fazer um tribunal exclusivamente constitucional, e consequentemente, um tribunal composto de maneira distinta. Seriam nove juízes de diferentes origens, alguns originários do próprio Judiciário, para a gente ter aquela experiência do homem que julgou 20/30 anos, que tenha patente, que tenha a experiência da coisa feita no dia-a-dia do Judiciário e que adquire aquela sensibilidade da coisa jurídica; não só um conhecimento, mas uma sensibilidade, uma destreza, uma arte. A arte do cirurgião na manipulação das leis. E queríamos também que viessem pessoas indicadas pelo Executivo, bacharéis em Direito evidentemente. E queríamos que esses juízes ficassem lá oito anos e depois disso não fossem para lugar nenhum, fossem viver o chamado ociumcum dignitatem. Quem julgou por oito anos as causas mais importantes do país não precisa fazer mais nada, vai ser curador de entidades culturais, vai dirigir entidades de direitos humanos, vai ser como o ex- 
presidente Jimmy Carter, correr o mundo para fazer o bem e aborrecer o mal. Não precisa fazer mais nada. Porque essa história de juiz do Supremo virar ministro e voltar a ser juiz não dá certo, não tem sentido.

Essa era a ideia. A ação direta de inconstitucionalidade, que a Constituição ampliou de uma maneira extraordinária, teria nesse tribunal o seu instrumento, correspondência necessária: um tribunal encarregado de controlar o poder do Legislativo e o poder do Executivo. Infelizmente, não conseguimos aprovar isso, houve muita emenda, muita pressão, porque isso daria o peso e o contrapeso. Teríamos um órgão com tremendo poder e tremenda capacidade de ação, para exercer aquele controle. O que saiu no final foi uma coisa meio mista, mas de toda maneira foi um avanço. Tanto foi um avanço que está sendo importante para o país a atuação do tribunal, apesar de limitado. Ou seja, ele não mudou de lugar, continua onde esteve sempre, está ali, mas com algumas modificações.

Minha segunda observação diz respeito a outra observação feita também pelo Lacombe. Ele diz que o político tem sempre uma desconfiança em relação ao Judiciário, pensa que o juiz usa a consciência como um certo álibi, e também disse que o político tem um temor reverencial da opinião pública. Eu sou filho de juiz, de modo que sou filho de um homem de saia, e um daqueles! Uma vez um repórter chegou para meu pai e disse assim: "Dr. Sampaio, o senhor não quer dar uma declaração sobre uma coisa?". Ele falou: "Dar o quê? O que é isso, meu filho? Juiz só fala nos autos". De modo que eu também sou dessa tradição: juiz só fala nos autos. Juiz não tem por que ter temor da opinião pública, não precisa saber o que pensa a opinião pública. Até certo limite. E aí eu gostaria de matizar. Acho que o político tem que ter temor reverencial da opinião pública, também até certo limite.

O juiz precisa ter um conhecimento mais profundo da realidade social, para ter uma certa ideia das consequências de suas decisões, que são consequências objetivas. Nossa tradição de Direito é positivista, uma tradição de interpretação literal da lei. O juiz não faz a lei e não deve fazer a lei. Essa história de sentença dada pela consciência do juiz pode tornar-se perigosíssima para os nossos direitos. Eu sou bem conservador quanto a esse ponto e discuti isso no Congresso. Acho que o juiz tem que olhar a lei e dizer o que está ali, não o que ele acha.

Mas isso até certo limite. A gente vê por aí liminares que são uma irresponsabilidade, que criam problemas enormes. Vocês provavelmente se lembram de uma decisão tomada por um juiz que causou um motim no Rio de Janeiro, uma verdadeira rebelião, e que teve que ser revertida rapidamente? Daí a importância de que o juiz esteja dentro da sociedade, que conviva com a sociedade. E importante flexibilizar essa relação. Estou falando do bom juiz e do político sério, porque para o mau juiz e o político safado esses parâmetros não valem.

Permitam-me que lhes recorde os tempos do governo Carvalho Pinto, aqui em São Paulo. Estávamos fazendo um plano e os nossos arquitetos e urbanistas, estudando a cidade de São Paulo, disseram o seguinte: "Um fórum só na Praça Clóvis é impossível, não dá para entender". Como íamos construir uma porção de cadeias na cidade, delegacias, etc. e íamos ter que desapropriar terrenos, surgiu alguém com a seguinte ideia: "Por que não desapropriamos terrenos maiores e fazemos fóruns distritais?". Evidentemente, pensamos no assunto, os jornais publicaram e um dia meu pai chegou em casa e me disse: "Plínio, o tribunal está uma fera com vocês". Isso para ele era a pior coisa que podia acontecer no mundo, para mim não era tanto, mas para ele o tribunal estar contra era uma barbaridade. Ele dizia: "O tribunal está muito contra vocês, diz que vocês estão inventando o "juiz de várzea". Eu perguntei quem estava nisso. Ele disse fulano, fulano, fulano, que eram meus amigos, tinham me visto pequeno. Eu disse: "Diz para eles que os ponho num ônibus amanhã e vou mostrar onde é que eu quero fazer os fóruns e porque". No dia seguinte chamei um cidadão, que hoje, aliás, é vereador aqui, o Chico Withaker. Pegamos um ônibus, convidamos 10 ou 12 juízes e ele os levou lá para a Vila Formosa. Todo mundo aqui sabe onde é a Vila Formosa e todo mundo sabe onde é aquela famosa torre daquele padre que teve um sonho e fez uma torre imensa do lado da igreja. Como aquele lado da zona leste é relativamente plano, naquela torre se tem uma visão extraordinária daquele mar de casinhas. Hoje já não é mais assim, mas naquele tempo era um mar de casinhas. Eu disse: "Chico, você pega os desembargadores, leva lá e põe no alto da torre para eles olharem". Tínhamos proposto seis fóruns distritais. Eles voltaram tão entusiasmados que aprovaram a criação de 12 . O fato é que não conheciam o lado de lá da cidade, porque nós pertencemos à classe social que mora do lado de cá. Digo nós porque também já fui promotor. Nós moramos para cá. Na hora em que um juiz dá uma liminar, ele precisa ter isso na cabeça.

Houve aqui uma importante observação sobre a necessidade de que os juízes não se envolvam. Eu também não sou muito favorável ao juiz ficar tomando cervejinha às 10 da manhã na Vila Maria para ser popular. Não gosto muito disso. O velho João Sampaio pegava ele. Não é isso que eu estou propondo. Não estou propondo a vulgarização do juiz. Sou favorável à cerimônia do juiz. Vou dizer a vocês que tenho certa dificuldade para chamar de você os meus colegas que hoje são desembargadores, porque fui criado nesse temor reverencial, na cerimônia que 
o juiz deve ter e sou favorável a isso, acho que está certo. Mas uma coisa é o respeito e uma certa distância, outra coisa é saber, é conhecer, é entrar dentro da favela, do cortiço, é conversar lá embaixo para ter uma ideia, por exemplo, do que é o sindicato, para não pensar que é um bando de baderneiros e ficar impressionadíssimo com o nível técnico das discussões, como eu outro dia fiquei. Nesse sentido, acho que precisamos fazer um esforço sério para fugir um pouco desse positivismo frio de quem faz uma subsunção do fato à lei sem nenhum conhecimento da realidade em que esse caso está acontecendo.

Finalmente, gostaria de dizer algo sobre o tema abordado pelo Dr. Mário Machado, que é o problema do controle externo. Eu propus o controle externo na Constituinte. Propus uma fórmula que obteve maioria, mas não foi aprovada porque faltaram oito votos para o quórum, isto é, para a maioria qualificada.

Qual é o problema do controle do Judiciário? É o problema de que todo poder deve ser controlado por outro poder. Só o poder controla o poder. O Judiciário precisa ter um certo controle. Na consciência do juiz, no julgamento, na sentença? Absolutamente não. Impossível, não tem o menor cabimento. Mas é preciso ver que o Judiciário tem um outro papel. O Judiciário não é apenas o juiz que tem A contra B, um caso, um direito, pega aquele fato, aquele direito e escreve num papel que é assim. Não é só isso. Ele é um poder encarregado de prestar um serviço fundamental, um serviço que exige uma complexa organização administrativa e uma quantidade considerável de recursos.

Eu entendo que boa parte dessa terrível crise moral que se abateu sobre nosso país se deve à insuficiência e à ineficiência dos nossos serviços judiciários. É fruto dessa prestação jurisdicional reprimida, dessa demanda de jurisdição reprimida que temos no Brasil. Eu quase faria aqui um desafio de saber quem foi assaltado e tentou levar o caso à justiça. Tenho certeza de que nesta sala existem várias pessoas que devem ter sido lesadas nos seus direitos e fizeram o seguinte raciocínio: "Será que vale a pena?". Como são pessoas de bom senso, concluíram que não vale a pena e preferiram sofrer, ou preferiram encontrar o chamado " $b y$ pass", preferiram resolver por outra via. O acúmulo dessas outras vias é que engendrou o clima moral que estamos vivendo.

Para não cairmos no problema do espelho, quem controla o Judiciário? $\mathrm{O}$ órgão tal. E quem controla o órgão tal? Quem controla o órgão que controla? Qualquer órgão estável que se faça cria uma dificuldade muito grande. Seja porque a pessoa ali depois vai voltar a uma outra posição na qual ela pode ser sancionada, seja porque ela adquire uma vantagem comparativa evidente em relação aos demais.
Então a mim me pareceu que a melhor solução para o controle do Judiciário seria o controle disciplinar da conduta dos juízes (o controle interno do funcionamento da máquina) ficar com os órgãos que já existem no tribunal. Mas o presidente do tribunal teria que fazer, uma ou duas vezes ao ano - isso teria que ser estudado -, o que eu chamei de uma relação da justiça. Isso significa que ele teria que ir ao Legislativo e explicar por que a sentença tal absolveu ou condenou? Absolutamente não. Nem caberia discutir isso. Mas explicar, por exemplo, por que a distribuição de um processo na Justiça do Trabalho em Brasília demora um ano e meio e por que alguns advogados a obtém em 15 dias? Por que há uma porcentagem considerável de detentos que ficam na prisão além do tempo da pena? O que é uma violência. Por que no Tribunal de Justiça de certos estados, 70 ou $80 \%$ dos funcionários administrativos são parentes dos desembargadores? Fatos como esses deveriam ser explicados à Nação. E a melhor coisa é explicar a um órgão (o legislativo) onde as pessoas não serão necessariamente as mesmas. Se fosse em 1988, eu provavelmente o arguiria. Se fosse agora, eu não poderia mais fazê-lo porque já não sou deputado. A rotatividade do Legislativo impediria que alguém tivesse a condição permanente de exercer esse controle. E esse controle seria apenas o da publicidade, o controle mais forte na democracia, que é o resultante de as coisas serem ditas em público. O peso de dizer em público aquilo que está errado. O presidente do tribunal teria que ir e ouvir um padrezinho do Tocantins perguntar por que um processo para punir o assassinato de um líder posseiro está há três anos parado no fórum tal. Vocês podem imaginar a força que teria essa pergunta na frente de deputados, de senadores, da televisão e da imprensa. Acho que isso bastava, não precisava mais nada. E isso não entra na consciência do juiz, não entra na prestação jurisdicional individual. Não entra no funcionamento de um órgão que tem a obrigação de prestar um serviço, que não está prestando esse serviço a contento, e essa é uma das causas da crise brasileira.

\section{Debate}

\section{Bolívar Lamounier}

Acho que todos perceberam porque a Maria Tereza Sadek, quando organizou este seminário, fez uma convocação veemente ao Plínio Sampaio para esta discussão. Tenho agora a satisfação de franquear a palavra para os debates finais. 


\section{Liliana Mercadante}

Sou promotora de justiça criminal em São Paulo e também integro a diretoria do Movimento do Ministério Público Democrático. Minha pergunta é dirigida ao Dr. Plínio Sampaio. No momento em que se fala em controle externo do Judiciário e até em controle externo do Ministério Público, não parece um contrassenso que tenha surgido justamente nesse contexto uma emenda constitucional que dá ao Supremo Tribunal Federal o poder de fazer a lista tríplice para a escolha do procurador geral da República? O que causa uma estranheza maior é que justamente quando se está falando no controle do Judiciário surge uma proposta como essa, que parece ter como objetivo constranger as atitudes que o Ministério Público tem tomado, e que tiveram um salto qualitativo importante a partir do momento em que o procurador geral da República passou a ter mandato, por conseguinte pôde agir com mais liberdade, e agiu efetivamente em episódios recentes. Gostaria que o senhor tecesse um comentário sobre esse ponto, que me parece ser um gritante paradoxo.

\section{Plínio de Arruda Sampaio}

Concordo inteiramente, não tem o menor sentido isso. O Ministério Público está se tornando um verdadeiro quarto poder. É realmente um processo de construção constitucional, e um processo singular, que está acontecendo no Brasil: uma instituição que começa a ganhar corpo e se percebe que ela não tem lugar na tripartição clássica dos poderes. Nós tínhamos proposto o controle externo do Ministério Público da mesma maneira, e também nisso fui derrotado. Fui derrotado também no seguinte ponto: juiz e promotor não podem fazer política. Eu sei que todo mundo olha para mim e diz: "Que moral você tem se começou como promotor público e fez política a vida inteira?". O fato de eu ter errado não quer dizer que não esteja errado. Realmente, com o poder que tem o promotor hoje não pode pertencer a um partido político, não pode ser candidato, não pode ser secretário de Estado. Não pode porque ele simplesmente gera uma extraordinária suspeição sobre sua atuação. É óbvio. Fui derrotado e vocês estão vendo os fatos. Acho que não tem o menor sentido, quebra totalmente a sistemática do instituto, a lista tríplice ser elaborada no Poder Judiciário. Isso tem mais cara de represália.

\section{Alfredo Attié Jr.}

Sou juiz de direito e pertenço à Associação Juízes pela Democracia. Minha pergunta é dirigida ao Dr. Plínio de Arruda Sampaio e ao Dr. Mário Machado. Eu não fui entrevistado na pesquisa, mas me enquadro naquela minoria que admite a crise do Judiciário e que é favorável ao controle externo. Evidentemente a um controle externo e não ao controle interno que está sendo inventado nessa revisão constitucional pelo deputado Nelson Jobim ou por aqueles que o assessoram ou apoiam. Será que não estaria faltando ao Poder Judiciário um projeto? Será que o que se cobra efetivamente do Judiciário não é uma verdadeira política de um poder e daí a necessidade desse controle para que a sociedade possa vir a participar dessa política? Para dar um exemplo que tem sido utilizado com frequência pelo professor Fábio Konder Comparato, há uma necessidade clara, na medida em que o Judiciário tem a obrigação de prestar jurisdição no que diz respeito às crianças e aos adolescentes, como se diz atualmente, de se criar varas de crianças e adolescentes em maior número até do que varas cíveis e varas penais. Há necessidade de se aparelhar o Judiciário para resolver essa questão da criança e do adolescente, que é uma questão fundamental. No entanto, não se vê esse empenho dos tribunais.

Outra preocupação minha: será que o controle externo na forma proposta pelo então deputado Plínio de Arruda Sampaio, que seria exercido pelo próprio Poder Legislativo, não permitiria um acordo entre esses poderes, tendo em vista que o Poder Legislativo também tem os seus defeitos graves? Não deveria o controle externo ser efetivamente exercido pela sociedade, por um mecanismo da sociedade, que controlasse efetivamente os poderes e não apenas o Poder Judiciário? Para citar novamente um autor clássico, Locke previa essa permanência do poder do povo para aparecer e revogar mandatos e recuperar, digamos assim, a sua capacidade de reconstituir o Estado.

\section{Mário Machado}

É uma questão bastante difícil. Minha reflexão foi sobre os fundamentos dessa problemática, não tenho amadurecido o modus faciendi (digamos assim, numa homenagem aos juristas presentes) ideal para o controle externo. Lembro que a Constituição de 1988, no artigo 49, inciso 10, atribui ao Legislativo o poder "de fiscalizar e controlar diretamente ou por qualquer de suas casas os atos do Poder Executivo, incluídos os da administração indireta". Quando falo em controle externo do Judiciário, não estou necessariamente falando na existência de um órgão. 
Pode ser o próprio Legislativo; se ele controla o Executivo, por que não também o Judiciário? Mas não tenho uma reflexão amadurecida quanto a esse ponto.

Com relação a essa citação de Locke, que é importante, acho que ela deve ser tomada com certa cautela. De início, Locke nem tratava do Poder Judiciário. Ao tratar da separação de poderes, ele falava apenas do Legislativo e do Executivo. Em certo momento, ele fala de um terceiro poder, o de declarar a guerra e a paz, mas diz que isso no fundo deve ficar nas mãos do Executivo também. Afirma que o poder soberano é o Legislativo, que os outros devem a ele subordinar-se. Mas diz também que o próprio Poder Legislativo deve subordinarse ao poder soberano do povo e que, se o Legislativo ou o Executivo ou ambos escapam à missão que lhes foi confiada, se desencaminham do encargo que lhes foi confiado, então o povo tem o direito de modificar ou afastar o Legislativo ou o Executivo. Quem decidirá se o Legislativo ou o Executivo deixaram de desempenhar suas funções? A isso Locke responde: "O povo será o juiz". Aí está claro o fundamento da soberania que eu acho que se aplica ao Legislativo, ao Executivo e também ao Judiciário.

O problema é a cautela política que se requer,quando pensamos em remeter a solução desses conflitos institucionais frequentemente à consulta popular. Até que ponto as dificuldades encontradas no relacionamento institucional deveriam necessariamente levar à busca de uma solução externa, a todo momento, nas raízes, ou seja, na soberania popular? Essa é uma questão política delicada, em relação à qual a minha recomendação seria de cautela. Eu pessoalmente tenho uma admiração muito grande pela ideia da representação política. Minha tendência sempre é a do fortalecimento do Legislativo, ainda que em momentos cruciais, como no caso de um impeachment, deva-se ir diretamente ao fundo da soberania, via Legislativo ou via consulta popular. É uma maneira muito mais simples de resolver o problema hoje em dia. Afinal de contas, todos aqueles mecanismos que foram criados para o impeachment de um presidente resultavam de uma época em que havia uma enorme dificuldade em consultar a opinião pública. Se isso hoje em dia é tão fácil, não vejo muita razão para que o impeachment seja ainda decidido pelo Congresso. Poderia ser decidido pela soberania, isto é, pelo povo. Mas tenho certo receio de que um excesso de consultas diretas possa enfraquecer a representação via Legislativo. Mas, como disse, não tenho uma opinião definitiva sobre esses pontos.

\section{Bolívar Lamounier}

Por essa técnica, o presidente Clinton teria sido impedido em seu centésimo dia de governo. O Dr. Plínio Sampaio também quer se pronunciar sobre essa questão.

\section{Plínio de Arruda Sampaio}

O Legislativo é controlado pelo Executivo. O Executivo pode vetar a lei. Ele é controlado pelo Judiciário. O Judiciário declara inconstitucional a lei. Executivo e Legislativo são controlados pelo povo, porque de quatro em quatro anos têm que pedir para continuar. E são controlados pela opinião pública. Nesse sentido, eu penso que a soberania do povo brasileiro está assegurada, inclusive pelas liberdades constitucionais.

O controle que eu propus é o seguinte: o Legislativo não tomaria nenhuma medida, ele simplesmente permitiria que a sociedade organizada sentasse com o juiz, o presidente aqui, sociedade ali; presidente da Comissão de Justiça e Paz, presidente da comissão dos direitos humanos, toda essa cambada de que o Amaral Neto tem ódio. Sentava todo mundo ali, CIMI, associações indígenas, padres, freiras, líderes sindicais, posseiros, essa coisa "horrorosa", sentava tudo ali e dizia: “Ô doutor, como é que é isso?". É para o tribunal sentir. E os deputados olhariam, poderiam fazer suas perguntas e eventualmente a comissão de justiça da Câmara poderia fazer recomendações, que seriam aceitas ou não pelo Judiciário. Eu fiz questão (e esta foi uma das coisas que nós conseguimos) de que o Judiciário tivesse plena autonomia para fazer o seu orçamento e para se organizar. Ficou estabelecido que é preciso criar uma justiça especial para julgar expeditamente as causas mais simples, aquelas causinhas em que você diz: "Vem aqui, você não quer acertar com ele aqui?”. E que são importantes. Esses tribunais não estão sendo levantados.

O Tribunal de Justiça tem autonomia financeira para fazer o seu orçamento e levá-lo ao Congresso. Mas não, ele insiste em fazer isso através de uma providência administrativa do Executivo, pedindo um percentualzinho assim a mais. Numa reunião dessas a que me refiro, o juiz poderia responder o seguinte: "Não posso atender a sua demanda porque não tenho recursos". E o deputado teria força para dizer o seguinte: "Ah, o problema é recurso? O senhor peça que nós damos". Percebem como mudava? Esse mecanismo não permitiria suspender um juiz, suspender um tribunal, nenhuma atitude desse tipo. Permitiria ouvir e sugerir. 


\section{Miguel Chaia}

Sou do Departamento de Política da PUC de São Paulo e editor da revista São Paulo em Perspectiva.

Considerando as exposições feitas nessa sessão, parece-me que a questão do Judiciário no Brasil, diferentemente da história inglesa ou norte-americana, não se coloca numa situação de fundação de um Estado, e sim de construção e aprimoramento das instituições. Ou seja, essa separação de poderes no Brasil adquire um significado muito especial. Antes de mais nada, trata-se de desequilíbrio de poderes. À medida que esse Estado vem se consolidando, podemos verificar que estamos tratando de um desequilíbrio de poderes, onde temos historicamente um Executivo extremamente forte, uma tendência a um presidencialismo muito forte e atuante, um Legislativo que teve durante o Império seu papel mais importante e tenta retomá-lo mais tarde, e um Judiciário que acaba se travestindo numa espécie de poder moderador. Na verdade, é quase que um terceiro ou quarto poder que passa a controlar os dois e os demais poderes. Aí é que vem a questão: a crise do Judiciário não aparece quando surgem vácuos de poder, exigindo nova conformação para essas instituições em crise? Por exemplo, quando a igreja ou o exército são chamados não respondem mais à necessidade de interferir como poder moderador. O Judiciário aparece, então, como tal, e entra em crise precisamente porque nessa situação, em função de um deslocamento com a sociedade, da forma até do ingresso dos juízes, acaba se afastando da sociedade. A crise então aparece com maior força. São essas as questões sobre as quais gostaria de ouvir as reflexões da mesa.

\section{Andrei Koerner}

Sou pós-graduando do Departamento de Ciência Política da USP. Eu gostaria comentar a exposição do Dr. Mário Machado. Acho que o motivo dessa questão da independência dos poderes é histórico. No início da República, se os juízes dessem um habeas corpus em que estivesse envolvido um ministro militar, ou no momento em que um militar estivesse na presidência, receberiam como resposta, como receberam, que o juiz extrapolou de suas funções e se meteu na esfera dos outros poderes. Portanto, ele era impedido de cumprir a ordem. Por isso foi construída uma teoria da separação dos poderes que diz o seguinte: os poderes são independentes e harmônicos entre si, e o Judiciário está excluído do caso político. Essa doutrina do caso político foi ampliada em relação à doutrina norteamericana das dimensões internas do Judiciário. Neste sentido, acho que existe um motivo corporativo quando o Judiciário e os juízes contestam o controle externo. Mas essa questão da independência dos poderes e da exceção do caso político é invocada por militares, por regimes autoritários, exatamente para afastar o Poder Judiciário do controle dos atos dos outros poderes.

$\mathrm{Na}$ questão do controle da magistratura por órgão externo, gostaria de fazer uma colocação aos três palestrantes. O Dr. Eugênio Zafaroni colocou uma questão muito interessante: há que se considerar três funções dos órgãos superiores da magistratura. A primeira seria a de rever as decisões de primeira instância, a segunda seria o governo dos juízes, e a terceira seria o controle dos atos dos outros poderes. O problema da democratização, da construção de um Poder Judiciário democrático, seria separar essas três funções em órgãos diferentes. No que tange à questão do governo dos juízes, ele coloca que uma inovação importante no caso italiano é justamente a representação interna. Não existe diferença na medida em que os juízes de primeira instância, no início de carreira, têm condições de eleger seus representantes para esse órgão que faz o governo dos juízes. É uma diferença importante na medida em que se quebra a tendência corporativa e de reprodução das estruturas burocráticas do Judiciário.

\section{Floriza Verucci}

Sou do Conselho da OAB e do Conselho Estadual da Condição da Mulher de São Paulo. Esses questionamentos estão ocorrendo hoje no Brasil. Questionamos o Poder Executivo, depois o Poder Legislativo, que continua sob questionamento, e agora o Judiciário, o que é uma novidade, e é muito importante esse questionamento. Pergunto se é realmente possível discutir o equilíbrio dos poderes, do controle entre os poderes, sem tentar também elucidar a questão da Federação no Brasil?

\section{Cláudio Lacombe}

Respondendo à primeira questão, realmente a doutrina da supremacia judicial, elaborada por Marshall, foi para estabelecer o Poder Judiciário como árbitro, como poder moderador, árbitro do equilíbrio e da distribuição dos poderes entre o Executivo, o Legislativo e entre a União e os Estados, além de guarda das liberdades. O Poder Judiciário entra em conflito com os outros poderes quando surge a crise política ou a crise social. Ele não toma iniciativas, porque é um poder passivo, só se manifesta quando é provocado por particulares, pelo próprio governo, pelos partidos políticos. Ele pode se envolver na crise. Conforme a 
decisão, se ele desagrada uma das facções em luta, pode provocar uma ruptura institucional. Mas não necessariamente. Aqui no Brasil, nunca uma decisão do Poder Judiciário provocou a ruptura. O Judiciário foi vítima de crises institucionais, nunca agente produtor de tais crises. Quando uma crise eclode, e o Poder Executivo não está de acordo com a decisão do Judiciário, não a cumpre. O Judiciário é um poder desarmado, não tem como fazer cumprir a sua decisão. Eu citei o presidente Andrew Jackson que se recusou a cumprir uma decisão da Corte Suprema, e o próprio Lincoln. Isso realmente não tem solução institucional. Na hora em que estoura a crise, é o salve-se quem puder.

\section{Plínio de Arruda Sampaio}

Vou fazer um comentário sobre a Federação, como sugere a Floriza Verucci. Fica uma sugestão ao IDESP para que faça um estudo sobre a Federação. Eu fui criado com um temor reverencial total. A Federação para mim sempre foi sagrada. Mas quando me tornei deputado, comecei a me perguntar: que federação? Historicamente, este país não tem federação. A Federação americana formou-se a partir de vários Estados, de oligarquias que foram capazes de construir Estados, porque tinham duas coisas: dinheiro e exército. Quem não tem dinheiro e não tem exército, não tem Estado. Essas oligarquias se reuniram e fizeram uma confederação, brigaram, deu um pau daquele tamanho, e aí fizeram um pacto, que foi o Pacto Federativo. Aqui não tivemos isso. Tivemos oligarquias que foram mantidas sob controle por um poder unitário e que nunca construíram elas mesmas os seus Estados. O Piauí tem exército, tem condição de comprar um canhão? Então, eu acho que precisamos repensar isso. Não tenho condição de aprofundar agora este assunto, mas gostaria que o IDESP organizasse um debate sobre isso.

\section{Bolívar Lamounier}

Está aceita a sugestão. Quero encerrar este seminário agradecendo a presença de todos e salientado que este trabalho sobre o Judiciário, sobre as instituições ligadas à Justiça, sobre as profissões ligadas à Justiça, ainda é muito incipiente no Brasil. É incipiente no próprio IDESP. Outras instituições estão trabalhando nessa área, desenvolvendo estudos muito promissores, mas penso que a soma desses esforços ainda é modesta. O diálogo entre os profissionais e instituições dessa área com as ciências sociais ainda está engatinhando. Para nós do IDESP, este é um programa de longo prazo. Não é um seminário, não é uma pesquisa, é um programa que desejamos desenvolver, com o objetivo de contribuir para o aperfeiçoamento da Justiça no Brasil.
Além de agradecer a presença e a colaboração de todos, quero reiterar, em nome do IDESP, o pedido de que colaborem conosco, que nos ajudem, porque este é um campo ainda muito pouco explorado. Só poderemos prosseguir e produzir alguma coisa útil se continuarmos a contar com a colaboração de todos vocês. Muito obrigado e até a próxima oportunidade. 


\section{ANEXO: A PESQUISA}

Tabela 1 - O Judiciário está em crise?

(em porcentagens)

\begin{tabular}{|c|c|c|c|}
\hline $\begin{array}{c}\text { Concorda } \\
22,5 \\
\end{array}$ & $\begin{array}{c}\text { Concorda em termos } \\
54,4 \\
\end{array}$ & $\begin{array}{c}\text { Discorda } \\
20,5 \\
\end{array}$ & $\begin{array}{c}\text { Sem opinião } \\
2,6 \\
\end{array}$ \\
\hline
\end{tabular}

Texto da pergunta: Tem-se
concorda com essa afirmação?

Tabela 2 - Quem tem interesse em salientar essa crise? (em porcentagens)

\begin{tabular}{lc}
\hline Agentes & Têm interesse (*) \\
Imprensa & 64,4 \\
OAB & 54,2 \\
Advogados & 54,1 \\
Legislativo Federal & 45,3 \\
Executivo Federal & 33,7 \\
Igreja/CNBB & 32,5 \\
Juristas & 29,8 \\
Promotores & 26,0 \\
Polícia & 24,7 \\
Correntes do próprio Judiciário & 22,5 \\
Empresários & 21,6 \\
Instâncias superiores da magistratura & 11,3 \\
(*) Soma das respostas "fortemente interessado" $e$ "muito interessado" & \\
\hline
\end{tabular}

Texto da pergunta: Em que medida os agentes seguintes têm interesse em salientar a existência de crise no Judiciário?

A existência da crise no judiciário é admitida por $22,5 \%$ dos entrevistados. A imprensa é vista por $64,4 \%$ como o principal interessado em salientar a existência de crise no judiciário. Vêm em seguida a OAB, os advogados e o legislativo federal. Segundo os juízes, a existência de uma crise no judiciário é salientada, sobretudo por agentes externos a ele.
Tabela 3 - Obstáculos ao bom funcionamento do Judiciário (em porcentagem)

\begin{tabular}{lc}
\hline Fatores & Importância (*) \\
Falta de recursos materiais & 85,6 \\
Excesso de formalidades nos procedimentos judiciais & 82,3 \\
Número insuficiente de juízes & 81,1 \\
Número insuficiente de varas & 76,3 \\
Legislação ultrapassada & 67,4 \\
Elevado número de litígios & 66,5 \\
Despreparo dos advogados (causas mal propostas, etc.) & 64,0 \\
Grande número de processos irrelevantes & 59,3 \\
Juízes sobrecarregados com tarefas que poderiam ser delegadas & 59,1 \\
Instabilidade do quadro legal & 53,2 \\
Insuficiência na formação profissional do juiz & 38,9 \\
Extensão das comarcas & 26,8 \\
Curta permanência dos juízes nas comarcas & 25,3 \\
(*) Soma das respostas "extremamente importante" e "muito importante” &
\end{tabular}

Texto da pergunta: Na instância em que o Sr.(a) atua, qual a importância dos seguintes fatores como obstáculos ao funcionamento adequado do Judiciário?

O principal obstáculo é a falta de recursos materiais. Vem em seguida o formalismo, considerado excessivo e o número insuficiente de juízes e de varas. Os fatores menos relevantes, na avaliação dos entrevistados, são as insuficiências de formação profissional, a extensão das comarcas e a curta permanência dos juízes nas comarcas.

\section{Tabela 4 - Causas da morosidade da Justiça}

(em porcentagens)

Fatores Importância $(*)$

Alto número de recursos 73,2

Interesse dos advogados

Interesse das partes envolvidas no processo

Lentidão dos Tribunais de Justiça

Interesse do poder executivo

Comportamento da polícia/delegacia

Comportamento dos cartórios

Morosidade dos juízes

Intervenção excessiva da promotoria

(*) Soma das respostas "extremamente importante" $e$ "muito importante"

Texto da pergunta: Que peso o Sr.(a) atribui aos seguintes fatores como causas da morosidade da Justiça?

A morosidade decorre, sobretudo, do alto número de recursos e, em boa medida, das estratégias protelatórias adotadas pelos advogados e pelas partes. A eventual lentidão dos próprios juízes não é vista como causa importante da morosidade. 
Tabela 5 - Como agilizar o Judiciário (em porcentagem)

\section{Propostas}

Informatização dos serviços judiciários

Redução das formalidades processuais

Juizados Especiais de Pequenas Causas

Simplificação no julgamento dos recursos

Recurso mais frequente à conciliação prévia extrajudicial entre as partes

Limitação do número de recursos às instâncias superiores por processo

Reforço da figura do árbitro, escolhido pelas partes, para julgar questões trabalhistas

Implementação da Justiça Agrária prevista na Constituição de 1988

Implementação da Justiça de Paz

Criação da Justiça Municipal

(*) Soma das respostas "extremamente importante" e "muito importante".

Texto da pergunta: Como o Sr.(a) avalia as seguintes propostas para agilizar o funcionamento do Judiciário?

As propostas consideradas mais eficazes são a informatização, a redução das formalidades processuais e a implantação dos juizados especiais de pequenas causas.

\section{Tabela 6 - Avaliação de mudanças introduzidas pela Constituição de 1988} (em porcentagens)

\section{Modificações}

Mandado de segurança coletivo

Reforço da função de controle constitucional do STF

Favorável $(*)$

Legitimação de novos agentes para propor ação de inconstitucionalidade

Mandado de injunção

Ampliação das atribuições do Ministério Público

(*) Soma das respostas "inteiramente favorável" e "muito favorável".

Texto da pergunta: Considerando o funcionamento global das instituições do país, qual a sua opinião sobre as seguintes modificações introduzidas pela Constituição de 1988 ?

Com exceção da ampliação das atribuições do Ministério Público, as alterações introduzidas pela Constituição de 1988 são vistas de maneira positiva pela maioria dos entrevistados.
Tabela 7 - Atuação de diversos órgãos públicos (em porcentagens)

Orgãos públicos

Superior Tribunal de Justiça

Justiça comum estadual

Supremo Tribunal Federal

Justiça Eleitoral

Justiça Federal

Ministério Público Federal

Ministério Público Estadual

Justiça do Trabalho

Governo Federa

Justiça Militar

Advocacia Geral da União

Governo Estadual

Congresso Nacional

(*) Soma das avaliações "ótima" e "boa".

Texto da pergunta: De maneira geral, como o Sr.(a) avalia a atuação dos seguintes órgãos e poderes, nos últimos 12 meses?

Tem sido boa a atuação dos órgãos judiciários na visão dos magistrados. O órgão avaliado de maneira mais positiva é o Superior Tribunal de Justiça. Vêm em seguida a Justiça Comum, o Supremo Tribunal Federal e a Justiça Eleitoral. O Executivo e o Legislativo são duramente criticados: os governos estaduais e o Congresso Nacional são os que tiveram pior atuação, segundo os entrevistados.

\section{Tabela 8 - Atuação do Supremo Tribunal Federal} (em porcentagens)

\begin{tabular}{lc}
\hline Funções & Avaliação Positiva (*) \\
Assegurar o cumprimento da Constituição & 64,9 \\
Assegurar o equilíbrio político entre os poderes & 52,5 \\
Dar eficácia às novas garantias instituídas, como o mandado de injunção, & 36,8 \\
$\quad$ o mandado de segurança coletivo e o habeas data & 20,7 \\
Compatibilizar a ordem jurídica com o imperativo de combate à inflação & \\
(*) Soma das avaliações "ótima" e "boa". &
\end{tabular}

(*) Soma das avaliações "ótima" e "boa".

Texto da pergunta: Como o Sr.(a) avalia a atuação do STF nas seguintes funções, desde 1988 ?

O STF, na opinião dos juízes, tem cumprido bem suas funções constitucionais de guardião

da Constituição e de árbitro entre os poderes. Sua atuação no tocante aos novos instrumentos constitucionais voltados para a defesa de interesses individuais e coletivos é vista de forma menos positiva. Na função de compatibilizar a ordem jurídica com o imperativo de combate à inflação, a atuação do STF não agrada aos magistrados. 
Tabela 9 - Atuação do Ministério Público Federal (em porcentagens)

Funções

Promover a ação penal pública

Atuação Positiva (*) público e social, do meio ambiente, de outros interesses difusos e coletivos

*) Soma da avaliaç̃oes "ótima" e "boa".

Texto da pergunta: Como o Sr.(a) avalia a atuação do Ministério Público Federal nas seguintes funções, desde 1988 ?

A atuação do Ministério Público é vista com reservas pelos juízes, sobretudo no que se refere à promoção da ação de inconstitucionalidade.

\section{Tabela 10 - Avaliação da Ação de Constitucionalidade e da Avocatória} (em porcentagens)

\section{Ação de constitucionalidade com efeito vinculante para as instâncias inferiores \\ O STF avocar processos de quaisquer juízos ou tribunais do país, quando \\ Favorável (*) \\ decorrer ameaça à ordem, à saúde, à segurança ou às finanças públicas}

(*) Soma das respostas "inteiramente favorável" e "muito favorável".

Texto da pergunta: O Sr.(a) é favorável ou contrário à ...?

A concentração de competências de controle constitucional e de corte especial para assuntos de relevância e urgência da União no Supremo Tribunal Federal não é avaliada de maneira positiva por parte dos entrevistados.

\section{Tabela 11 - Controle externo do Judiciário}

\section{em porcentagem}

\begin{tabular}{|c|c|c|c|}
\hline $\begin{array}{l}\text { Algo favorável } \\
6,0\end{array}$ & \multicolumn{2}{|c|}{$\begin{array}{l}\text { Desfavorável } \\
86,5\end{array}$} & $\begin{array}{l}\text { Sem opinião } \\
1,5\end{array}$ \\
\hline \multicolumn{4}{|c|}{$\begin{array}{l}\text { Texto da pergunta: Tem-se proposto a criação de um órgão externo de controle do Poder } \\
\text { Judiciário. O Sr.(a) é favorável ou contrário à criação desse órgão? }\end{array}$} \\
\hline \multicolumn{4}{|c|}{$\begin{array}{c}\text { Tabela } 12 \text { - Como deve ser composto o órgão de controle externo } \\
\text { (em porcentagens) }\end{array}$} \\
\hline & Sim & Não & Sem opinião \\
\hline Poder Judiciário & 77,9 & 7,0 & 15,1 \\
\hline Juristas & 49,7 & 29,8 & 20,5 \\
\hline Ordem dos Advogados do Brasil & 32,1 & 48,8 & 19,1 \\
\hline Ministério Público & 26,0 & 54,2 & 19,8 \\
\hline Lideranças da sociedade & 23,7 & 56,1 & 20,2 \\
\hline Congresso Nacional & 10,7 & 70,2 & 19,1 \\
\hline Poder Executivo & 7,4 & 72,1 & 20,5 \\
\hline
\end{tabular}

Texto da pergunta: Caso venha a ser criado, esse órgão deve ser integrado por...
A proposta de criação de um órgão para o controle externo do Judiciário é quase unanimemente rejeitada pela magistratura. Caso seja aprovada, a preferência dos juízes é que esse órgão seja majoritariamente integrado por representantes do próprio Judiciário.

\section{Tabela 13 - A quem interessa o controle externo}

\section{(em porcentagem)}

Poder legislativo

Partidos políticos

Poder executivo

$\mathrm{OAB}$

Imprensa

Empresários

Ministério Público

Sociedade em geral

Grupos específicos do próprio judiciário

Cúpula do poder judiciário

(*) Soma das respostas "fortemente" $e$ "muito"

Texto da pergunta: Em que medida a proposta de criação de controle externo atende a interesses dos seguintes agentes.

O interesse na criação de um órgão externo de controle do Judiciário é atribuído principalmente ao Legislativo, aos partidos políticos e ao Executivo.

\section{Tabela 14 - Compatibilidade entre Direito atual e certos objetivos substantivos} (em porcentagens)

\section{Direitos}

Coletivos (do consumidor, dos aposentados, etc.)

Difusos (meio ambiente, etc.)

Dos setores menos privilegiados

(*) Soma das respostas "inteiramente" $e$ "muito".

Texto da pergunta: Em que medida os juízes têm conseguido compatibilizar a lei com proteção dos direitos...

A maioria dos entrevistados acha que existe compatibilidade entre o Direito positivo e a proteção dos direitos coletivos, mas admite certa tensão quando inquiridos sobre direitos difusos e, de maneira mais ampla, sobre as necessidades dos setores sociais menos privilegiados. 
Tabela 15 - Opinião sobre os limites do Direito Positivo (em porcentagens)

O Juiz não pode ser um mero aplicador das leis, tem que ser sensível aos problemas sociai $\operatorname{Sim}(*)$ A maior parte da população não tem acesso à justiça

O compromisso com a justiça social deve preponderar sobre a estrita aplicação da lei

O saber jurídico está dissociado da realidade brasileira

A aplicação das leis sempre beneficia os privilegiados

$\mathrm{O}$ direito positivo não permite o espírito crítico

*) Soma das respostas "concorda inteiramente" e "concorda muito"

Texto da pergunta: Em que medida o Sr.(a) concorda com as seguintes afirmações

A maioria dos entrevistados (73,7\%) entende que o juiz não deve ser "mero aplicador da lei".

Metade $(48,1 \%)$ reconhece que a maior parte da população não tem acesso adequado à justiça.

Os porcentuais de concordância com os demais itens são porém decrescentes, indicando forte

disposição, por parte dos juízes, de se manterem nos limites do Direito Positivo.

\section{O QUE É O IDESP}

\section{Perfil da Instituição}

Fundado em 1981, o IDESP é uma instituição privada, autônoma, apartidária e sem fins lucrativos. Dedica-se à pesquisa e à promoção do debate público com o intuito de contribuir para a consolidação e aperfeiçoamento da democracia representativa e a modernização da economia com o máximo possível de equidade social.

Dentro desses princípios, o IDESP já realizou numerosos projetos de pesquisa, prestou assessoria a organismos governamentais e não governamentais, e promoveu seminários e conferências no Brasil e no exterior. Para ampliar a divulgação de seus trabalhos, o Instituto criou, em 1990, a Editora Sumaré, já bastante conhecida do público brasileiro.

As atividades do IDESP são financiadas basicamente por meio de doações e contratos de pesquisa ou assessoria. Entre as entidades que têm contribuído para a sustentação do Instituto incluem-se grandes fundações internacionais, como as norte-americanas Ford, Tinker e Mellon, a brasileira Vitae e organismos governamentais brasileiros, como a FINEP, o CNPq, e a FAPESP.

Nossos seminários e conferências são sempre abertos ao público. Para assegurar a relevância pública de nossos trabalhos, relatórios de nossos projetos são enviados à imprensa, aos setores diretamente interessados e a representantes categorizados dos Três Poderes.

\section{Áreas de atuação}

Os estudos realizados pelo IDESP podem ser classificados em quatro grandes áreas:

1 - Reforma Política e Econômica: transição do governo militar ao civil no Brasil e em outros países da América Latina; avaliação de propostas de reforma politico-institucional; formação de apoio social para o controle da inflação e a modernização do setor público; reforma do Poder Judiciário; entre outros temas.

2 - Eleições e Partidos Políticos: história eleitoral e partidária do Brasil; opinião pública e comportamento eleitoral; votações e preferências do Congresso Nacional; funcionamento da Justiça Eleitoral; avaliação de propostas para a reforma dos sistemas eleitoral e partidário; 
3 - Desenvolvimento Cultural e Científico: história e avaliação dos estudos científico-sociais no Brasil; intercâmbio científico do Brasil com os Estados Unidos e a Europa; políticas governamentais em relação à ciência, à arte e à cultura; história social da arte no Brasil; história social e cultural da imigração para o Brasil, com trabalhos já realizados e publicados sobre os armênios, libaneses e japoneses, e em andamento sobre outros grupos;

4 - Análise e Avaliação de Políticas Públicas: com o objetivo de auxiliar na formulação ou implementação de políticas públicas, o IDESP já realizou estudos sobre formação de recursos humanos; a participação da mulher, do adolescente e da criança no mercado de trabalho; a qualidade da vida urbana; políticas de transporte público urbano e os determinantes políticos da política agrícola brasileira durante a última década - entre outros temas.

\section{NOTA SOBRE OS EXPOSITORES}

Bolívar Lamounier, doutor em ciência política pela Universidade da Califórnia (Los Angeles), pesquisador do IDESP.

Celso Campilongo, doutor pela Faculdade de Direito da USP, professor da PUC$\mathrm{SP}$ e pesquisador do CEDISO-USP.

Claudio Lacombe, advogado em Brasília, ex-membro da Comissão Provisória de Estudos Constitucionais ("Comissão Afonso Arinos").

Floriza Verucci, advogada, membro do Conselho da OAB e do Conselho Estadual da Condição da Mulher - São Paulo.

Joaquim Falcão, professor de direito constitucional da UFRJ, secretário-geral da Fundação Roberto Marinho e ex-membro da Comissão Provisória de Estudos Constitucionais ("Comissão Afonso Arinos").

José Renato Nalini, juiz do Tribunal de Alçada Criminal de São Paulo e coordenador dos cursos de aperfeiçoamento da Escola Paulista da Magistratura.

Manoel Alceu Afonso Ferreira, advogado, ex-conselheiro da OAB, ex-juiz do TRE-SP, ex-secretário de Justiça e de Defesa da Cidadania do Estado de São Paulo.

Maria da Glória Bonelli, doutora em sociologia pela UNICAMP, professora da UFSC e pesquisadora do IDESP.

Maria Tereza Sadek, doutora em ciência política pela USP, professora da USP e pesquisadora do IDESP.

Mário Brockmann Machado, doutor em ciência política pela Universidade de Chicago e pesquisador visitante do IPEA.

Plínio de Arruda Sampaio, ex-deputado federal pelo PT-SP.

Rogério Bastos Arantes, mestre em ciência política pela USP e pesquisador do IDESP.

Sérgio Adorno, doutor em sociologia pela USP, professor da USP e pesquisador do Núcleo de Estudos da Violência.

Sueli Carneiro, advogada, coordenadora de direitos humanos do Geledés.

Walter Ceneviva, advogado, articulista da Folha de São Paulo, professor aposentado de direito civil da PUC-SP. 